\title{
Multistage development of a hydrothermal W deposit during the Variscan late-orogenic evolution: the Puy-les-Vignes breccia pipe (Massif Central, France)
}

\author{
Matthieu Harlaux ${ }^{1,2, *}$, Christian Marignac ${ }^{1}$, Julien Mercadier ${ }^{1}$, Marc Poujol ${ }^{3}$, Marie-Christine Boiron ${ }^{1}$, \\ Kalin Kouzmanov ${ }^{4}$, Alfredo Camacho ${ }^{5}$, Saïda Alikouss ${ }^{6}$, Benjamin Roméo ${ }^{7}$, Bernard Mouthier ${ }^{8}$ and \\ Michel Cuney ${ }^{1}$ \\ ${ }^{1}$ Université de Lorraine, CNRS, GeoRessources, F-54000 Nancy, France \\ 2 Nevada Bureau of Mines and Geology, University of Nevada, Reno, Nevada 89557-0178, USA \\ 3 Univ Rennes, CNRS, Géosciences Rennes-UMR 6118, F-35000 Rennes, France \\ ${ }^{4}$ Department of Earth Sciences, University of Geneva, CH-1205 Geneva, Switzerland \\ ${ }^{5}$ Department of Geological Sciences, University of Manitoba, Winnipeg, Manitoba R3T 2N2, Canada \\ ${ }^{6}$ Department of Geology, Hassan II University of Casablanca, Geodynamics of old Chains Laboratory, Casablanca, Morocco \\ 7 SOQUEM INC., 1740 Chemin Sullivan, Val-d'Or, Québec J9P 7H1, Canada \\ 85 Quai André Lassagne, 69001 Lyon, France
}

Received: 9 May 2020 / Accepted: 7 June 2021 / Publishing online: 30 June 2021

\begin{abstract}
The Puy-les-Vignes W deposit, located in the northwestern French Massif Central (FMC), is a rare occurrence of a wolframite-mineralized hydrothermal breccia pipe hosted in high-grade metamorphic gneisses. We present an integrated study of this deposit aiming to characterize the ore-forming hydrothermal system in link with the Variscan late-orogenic evolution of the FMC. Based on a set of representative samples from the host rocks and mineralization, we describe a detailed paragenetic sequence and we provide the major and trace element geochemistry of the granitic rocks and $\mathrm{W}-\mathrm{Nb}-\mathrm{Ta}-\mathrm{Sn}-\mathrm{Ti}$ oxide minerals, in situ $\mathrm{U} / \mathrm{Pb}$ and ${ }^{40} \mathrm{Ar} /{ }^{39} \mathrm{Ar}$ geochronology, and a fluid inclusion study of quartz and wolframite. We demonstrate that the formation of this W-mineralized breccia pipe results from a multistage development related to four major episodes during the late Carboniferous. The first episode corresponds to the emplacement of an unexposed peraluminous granite at ca. $324 \mathrm{Ma}$, which generated microgranite dykes exposed at the presentday surface. The second episode is the formation of the quartz-supported breccia pipe and wolframite mineralization at ca. $318 \mathrm{Ma}$ at a paleodepth of $7 \mathrm{~km}$. The mineralizing fluids have a $\mathrm{H}_{2} \mathrm{O}-\mathrm{NaCl}-\mathrm{CO}_{2}-\mathrm{CH}_{4}-\mathrm{N}_{2}$ composition, a moderate-salinity $\left(<9 \mathrm{wt} . \% \mathrm{NaCl}\right.$ eq) and were trapped at high-temperatures $\left(>400^{\circ} \mathrm{C}\right)$ during lithostatic to hydrostatic pressure variations caused by hydrofracturing of the host rocks. Wolframite deposition is interpreted to result from a W-rich intermediate-density magmatic fluid that exsolved from an evolved leucogranite and interacted with volatile-rich metasedimentary country rocks and/or possibly mixed with low-salinity metamorphic fluids of deep origin. The third episode corresponds to magmatic-hydrothermal $\mathrm{Nb}-\mathrm{Ta}$ mineralization overprinting the $\mathrm{W}$-mineralized system interpreted to be related to the intrusion at ca. $311 \mathrm{Ma}$ of a rare-metal granite, which is part of a regional peraluminous rare-metal magmatism during the 315-310 Ma period. Finally, the last episode corresponds to disseminated $\mathrm{Bi} \pm \mathrm{Au}-\mathrm{Ag}$ mineralization emplaced at ca. $300 \mathrm{Ma}$, which shares similar mineralogical features with late Carboniferous orogenic gold deposits in the FMC. The Puy-les-Vignes W deposit records, therefore, a multistage and long-lived development that extends over a timespan of 25 million years in a regional setting dominated by protracted peraluminous magmatism and high-temperature and low-pressure metamorphism. Although the local environment of ore deposition is atypical, our results show that the mineral assemblages, alteration styles, and fluid characteristics of the Puy-les-Vignes breccia pipe are similar to those of other peri-granitic W deposits in the FMC.
\end{abstract}

Keywords: Puy-les-Vignes deposit / breccia pipe / wolframite mineralization / peraluminous granite / French Massif Central / Variscan belt

\footnotetext{
*Corresponding author: mharlaux@unr . edu
} 


\begin{abstract}
Résumé - Développement multiphasé d'un gîte hydrothermal à $W$ au cours de l'évolution tardiorogénique varisque : le conduit bréchique de Puy-les-Vignes (Massif Central, France). Le gîte à $\mathrm{W}$ de Puy-les-Vignes, situé dans le nord-ouest du Massif Central Français (MCF), est une occurrence rare de conduit bréchique hydrothermal minéralisé en wolframite et encaissé dans des gneiss de haut-degré métamorphique. Nous présentons une étude intégrée de ce gîte dans l'objectif de caractériser le système hydrothermal minéralisé en lien avec l'évolution tardi-orogénique varisque du MCF. Sur la base d'un ensemble d'échantillons représentatifs des roches encaissantes et de la minéralisation, nous décrivons une séquence paragénétique détaillée et nous présentons la géochimie des éléments majeurs et traces des roches granitiques et des oxydes de $\mathrm{W}-\mathrm{Nb}-\mathrm{Ta}-\mathrm{Sn}-\mathrm{Ti}$, la géochronologie $\mathrm{U} / \mathrm{Pb}$ et ${ }^{40} \mathrm{Ar} /{ }^{39} \mathrm{Ar}$ in situ, et une étude des inclusions fluides dans le quartz et la wolframite. Nous démontrons que la formation du conduit bréchique minéralisé en $\mathrm{W}$ résulte d'un développement multiphasé liée à quatre épisodes majeurs au cours du Carbonifère supérieur. Le premier épisode correspond à la mise en place d'un granite peralumineux nonaffleurant à environ $324 \mathrm{Ma}$, qui a produit des dykes de microgranites affleurant à la surface actuelle. Le second épisode est la formation du conduit bréchique quartzeux et de la minéralisation à wolframite à environ $318 \mathrm{Ma}$ à une paléo-profondeur de $7 \mathrm{~km}$. Les fluides minéralisateurs ont une composition à $\mathrm{H}_{2} \mathrm{O}-\mathrm{NaCl}-\mathrm{CO}_{2}-\mathrm{CH}_{4}-\mathrm{N}_{2}$, une salinité modérée $(<9 \mathrm{wt} . \% \mathrm{NaCl}$ eq) et ont été piégés à hautes températures $\left(>400^{\circ} \mathrm{C}\right)$ pendant des variations de pressions lithostatiques à hydrostatiques causées par la fracturation hydraulique des roches encaissantes. Le dépôt de la wolframite est interprété comme le résultat d'un fluide magmatique riche en $\mathrm{W}$ de densité intermédiaire issu d'un leucogranite évolué qui a interagit avec des roches métasédimentaires riches en volatiles et/ou s'est possiblement mélangé avec des fluides métamorphiques de faible salinité d'origine profonde. Le troisième épisode correspond à la formation d'une minéralisation magmatique-hydrothermale à $\mathrm{Nb}$-Ta se superposant au système minéralisé à $\mathrm{W}$ et lié à une intrusion de granite à métaux rares mise en place à environ $311 \mathrm{Ma}$, qui fait partie d'un magmatisme peralumineux à métaux rares d'échelle régionale pendant la période 315-310 Ma. Enfin, le dernier épisode correspond à une minéralisation disséminée à $\mathrm{Bi} \pm \mathrm{Au}-\mathrm{Ag}$ mise en place à environ $300 \mathrm{Ma}$ qui partage des similarités minéralogiques avec les gîtes d'or orogéniques tardi-Carbonifère du MCF. Le gîte à W de Puy-les-Vignes enregistre donc un développement multiphasé et de longue durée s'étalant sur 25 millions d'années dans un contexte régional dominé par du magmatisme peralumineux prolongé et du métamorphisme de haute température et basse pression. Bien que l'environnement de formation du gîte soit atypique, nos résultats montrent que les assemblages minéraux, les styles d'altérations et les caractéristiques des fluides du conduit bréchique de Puy-les-Vignes sont similaires à ceux d'autres gîtes péri-granitiques à $\mathrm{W}$ du $\mathrm{MCF}$.
\end{abstract}

Mots clés : gîte de Puy-les-Vignes / conduit bréchique / minéralisation à wolframite / granite peralumineux / Massif Central Français / chaîne Varisque

\section{Introduction}

Tungsten and tin mineralization worldwide is spatially associated with granitoid intrusions forming a large variety of magmatic-hydrothermal ore deposits including greisens, veins, stockworks, skarns, pegmatites, porphyries, and breccia pipes (Černý et al., 2005; Romer and Kroner, 2016). Peri-granitic vein systems represent an economically important class of $\mathrm{W}-\mathrm{Sn}$ deposits that are mostly spatially associated with metaluminous to peraluminous granitoids (Wood and Samson, 2000; Černý et al., 2005). The European Variscan belt is a large metallogenic province for $\mathrm{W}-\mathrm{Sn}$ and rare-metal $(\mathrm{Nb}, \mathrm{Ta}, \mathrm{Li}$, Be) deposits that are mainly located in Cornwall, the Erzgebirge, and the Iberian Massif (Romer and Kroner, 2016). In France, most W-Sn deposits are known in the French Massif Central (FMC; Marignac and Cuney, 1999), the Armorican Massif (Chauris and Marcoux, 1994), and the French Pyrenees (Poitrenaud et al., 2019). These deposits include wolframite-cassiterite-bearing quartz veins, greisen cupolas, and scheelite skarns spatially associated with Carboniferous peraluminous biotite-cordierite or two-mica granites (Stussi, 1989; Marignac and Cuney, 1999; Bouchot et al., 2005). Mining production for $\mathrm{W}$ in France was about
$26 \mathrm{kt} \mathrm{WO}_{3}$ until 1986 and remaining resources are estimated at about $83 \mathrm{kt} \mathrm{WO}_{3}$ (Audion and Labbé, 2012).

The Puy-les-Vignes $\mathrm{W}$ deposit, located in the northwestern FMC, represents the only known wolframite-mineralized hydrothermal breccia pipe in France. Another occurrence of wolframite-bearing breccia pipe is known at Borralha, Portugal (Gonçalves et al., 2017; Bobos et al., 2018). Tourmaline breccia pipes are commonly associated with porphyry $\mathrm{Cu}$ deposits (Sillitoe, 1985; Skewes et al., 2003; Anderson et al., 2009), reduced intrusion-related Au deposits (Baker and Andrew, 1991; Thompson et al., 1999; Chen et al., 2009), but more rarely with granite-related W-Sn deposits (Ren et al., 1995; Somarin and Ashley, 2004; Yang and Bodnar, 2004; Solomovich et al., 2012). Magmatic-hydrothermal breccia pipes generally form cylindrical subvertical bodies in the upper part of shallow intrusions. They are generally interpreted as resulting from hydraulic brecciation and collapse of the host rocks caused by ascending overpressured magmatic fluids (Sillitoe, 1985; Skewes et al., 2003; Yang and Bodnar, 2004; Demirel et al., 2009). Release of magmatic fluids from crystallizing intrusions under specific pressuretemperature conditions produces greater mechanical energy and volumetric expansion of the host rocks resulting in the 
formation of breccia pipes associated with silicification and tourmalinization (Burnham, 1985; Pollard et al., 1987; Halls, 1994).

In this work, we present an integrated study of the Puy-lesVignes $\mathrm{W}$ deposit aiming to characterize the formation of this atypical breccia pipe in link with the Variscan late-orogenic evolution of the FMC. Based on a set of representative samples from the host rocks and mineralization, we present a detailed paragenetic sequence of the deposit. Building on this sequence, we used a multi-method approach with the following objectives: (i) characterizing the major and trace element geochemistry of granitic rocks and $\mathrm{W}-\mathrm{Nb}-\mathrm{Ta}-\mathrm{Sn}-\mathrm{Ti}$ oxides, (ii) dating magmatic and hydrothermal events by in situ $\mathrm{U} / \mathrm{Pb}$ and ${ }^{40} \mathrm{Ar} /{ }^{39} \mathrm{Ar}$ geochronology, and (iii) determining the origin and the conditions of the mineralizing fluids based on a fluid inclusion study of quartz and wolframite. We demonstrate that the formation of the Puy-les-Vignes breccia pipe results from a multistage development between ca. 325 and ca. $300 \mathrm{Ma}$ in a regional setting dominated by protracted peraluminous granitic magmatism and high-temperature and low-pressure metamorphism.

\section{Geological setting of the Puy-les-Vignes W deposit}

The Puy-les-Vignes W deposit (Lat. 4549'34'N, Long. $\left.1^{\circ} 31^{\prime} 51^{\prime \prime} \mathrm{E}\right)$ is located in the Limousin area in the northwestern part of the FMC (Fig. 1A), which belongs to the inner zone of the European Variscan belt formed during the continental collision between Gondwana and Laurussia through the Upper Paleozoic (Faure et al., 2009a; Lardeaux et al., 2014). The geologic structure of the FMC consists of a stack of three major metamorphic nappes that are from top to bottom (Faure et al., 2009a and references therein): (i) the Upper Gneiss Unit (UGU) composed of ortho- and paragneisses derived from Cambrian to Early Ordovician protoliths (530-470 Ma; Alexandrov et al., 2001; Berger et al., 2010; Chelle-Michou et al., 2017; Lotout et al., 2017, 2018) having experienced medium-pressure and medium-temperature amphibolite- to granulite-facies metamorphism at 360-340 Ma (ChelleMichou et al., 2017); (ii) the Lower Gneiss Unit (LGU) consisting of ortho- and paragneisses similar to those of the UGU that were inherited from late Ediacarian protoliths (620$540 \mathrm{Ma}$; Alexandre, 2007; Melleton et al., 2010; ChelleMichou et al., 2017; Couzinié et al., 2017, 2019); and (iii) the Para-Autochtonous Unit (PAU) that consists of low-grade metasedimentary rocks (micaschists, metagreywackes, and quartzites) that were derived from Neoproterozoic to Early Cambrian protoliths (650-530 Ma; Melleton et al., 2010). These metamorphic units were intruded by numerous granitoids during the Carboniferous between 360 and $300 \mathrm{Ma}$ (Faure et al., 2009a; Lardeaux et al., 2014; Couzinié et al., 2017; Laurent et al., 2017; Moyen et al., 2017; Villaros et al., 2018).

The Puy-les-Vignes breccia pipe is hosted in migmatitic biotite-sillimanite paragneisses of the Saint-Léonard-deNoblat gneiss unit, which is structurally correlated with the LGU and is located on the southern flank of the Thaurion anticline (Fig. 1B). The deposit is situated $20 \mathrm{~km}$ south of the Saint-Sylvestre leucogranite complex dated at $324 \pm 4 \mathrm{Ma}$
(Holliger et al., 1986; Cuney et al., 1990) and $15 \mathrm{~km}$ west of the Millevaches leucogranite complex emplaced between $335 \mathrm{Ma}$ and $325 \mathrm{Ma}$ (Rolin et al., 2014). The breccia pipe is close to two peraluminous granites (Fig. 2A): the Auriat twomica granite in the northeast dated at $324 \pm 1 \mathrm{Ma}$ (Gebauer et al., 1981), and the Aureil biotite-cordierite granite in the southwest dated at $346 \pm 14 \mathrm{Ma}$ (Duthou, 1978). The breccia pipe has dimensions of $80 \times 340 \mathrm{~m}$ at surface and is cut in two parts (west and east) by a N30 E-trending sinistral strike-slip fault ("Faille Limite") with a 120-m horizontal displacement (Figs. 2B and 2C; Weppe, 1951, 1958). Only the eastern part of the breccia pipe was mined down to a depth of $300 \mathrm{~m}$ whereas the western part was barely explored. The vertical extent of the deposit is unknown, but an unexposed granite may exist at depth as described for other mineralized breccia pipes elsewhere (Sillitoe, 1985; Ren et al., 1995; Somarin and Ashley, 2004; Yang and Bodnar, 2004; Solomovich et al., 2012). Regional geophysical data reveal a low gravity anomaly with a NE-SW elongation around Puy-les-Vignes, suggesting a possible extension of the Auriat granite beneath the breccia pipe (Melleton et al., 2017). Microgranite and lamprophyre dykes, of 1-4 m thickness and NE-trending, are located at the intersection with the breccia pipe and are fragmented within the breccia (Fig. 2B; Weppe, 1951, 1958). Field relationships indicate that the microgranite postdate the lamprophyre. At depth, another NE-trending lamprophyre dyke crosscuts the breccia pipe possibly implying the existence of several generations of lamprophyre (Weppe, 1958). Similar lamprophyre dykes crosscutting the Saint-Sylvestre and Millevaches leucogranitic complexes yielded $\mathrm{Rb} / \mathrm{Sr}$ whole rock ages of $285 \pm 10 \mathrm{Ma}$ (Leroy and Sonet, 1976) and $290 \pm 5 \mathrm{Ma}$ (Chalier et al., 1994), respectively.

From a regional perspective, the Puy-les-Vignes deposit is centered on an extended W-As geochemical stream-sediments anomaly (>60 ppm W; Bertrand et al., 2015). Peri-granitic $\mathrm{W} \pm \mathrm{Sn}$ deposits occur regionally such as Mandelesse (Guyonnaud et al., 1977), Saint-Goussaud (Alikouss, 1993), and Vaulry (Vallance et al., 2001). Several W occurrences are known within a distance of $<2 \mathrm{~km}$ around the Puy-les-Vignes deposit, including quartz-wolframite veins and stockworks at the localities Lifarnet, Le Moulard, Les Clauds, Etivaud, Chassagnat and Beynat, as well as a second possible wolframite-bearing breccia pipe at Les Caillaudoux (Weppe, 1951, 1958; Fig. 2A). Additional quartz-wolframite veins have been documented in an area between Cheissoux and Villetelle, as well as a greisen-like cupola at Moissannes, respectively located at $15 \mathrm{~km}$ east and $10 \mathrm{~km}$ north of Puy-les-Vignes (Dudek, 1978). The Puy-les-Vignes deposit was mined underground between the mid $19^{\text {th }}$ and $20^{\text {th }}$ centuries (1855-1957) with a cumulated production of $3733 \mathrm{t} \mathrm{WO}_{3}$ at an average grade of $0.5 \% \mathrm{WO}_{3}$ (Mouthier, 2005) and was the second-ranked tungsten mine in France during the $20^{\text {th }}$ century. Proved reserves are estimated at about $1158 \mathrm{t} \mathrm{WO}_{3}$ based on mining archives (Melleton et al., 2017), but 3D numerical geologic modelling re-estimated reserves of $2500 \mathrm{t} \mathrm{WO}_{3}$ for the eastern part of the breccia pipe by considering a vertical extent of $235 \mathrm{~m}$ and an average grade of $0.2 \% \mathrm{WO}_{3}$ (J.J Royer, personal communication). Peñarroya, after a diamond drilling campaign in the 1970's on the unexploited western part of the Puy-les-Vignes breccia pipe, reported the discovery of a 4-m length intercept at $3 \% \mathrm{WO}_{3}$ (Melleton et al., 2017). The potential 


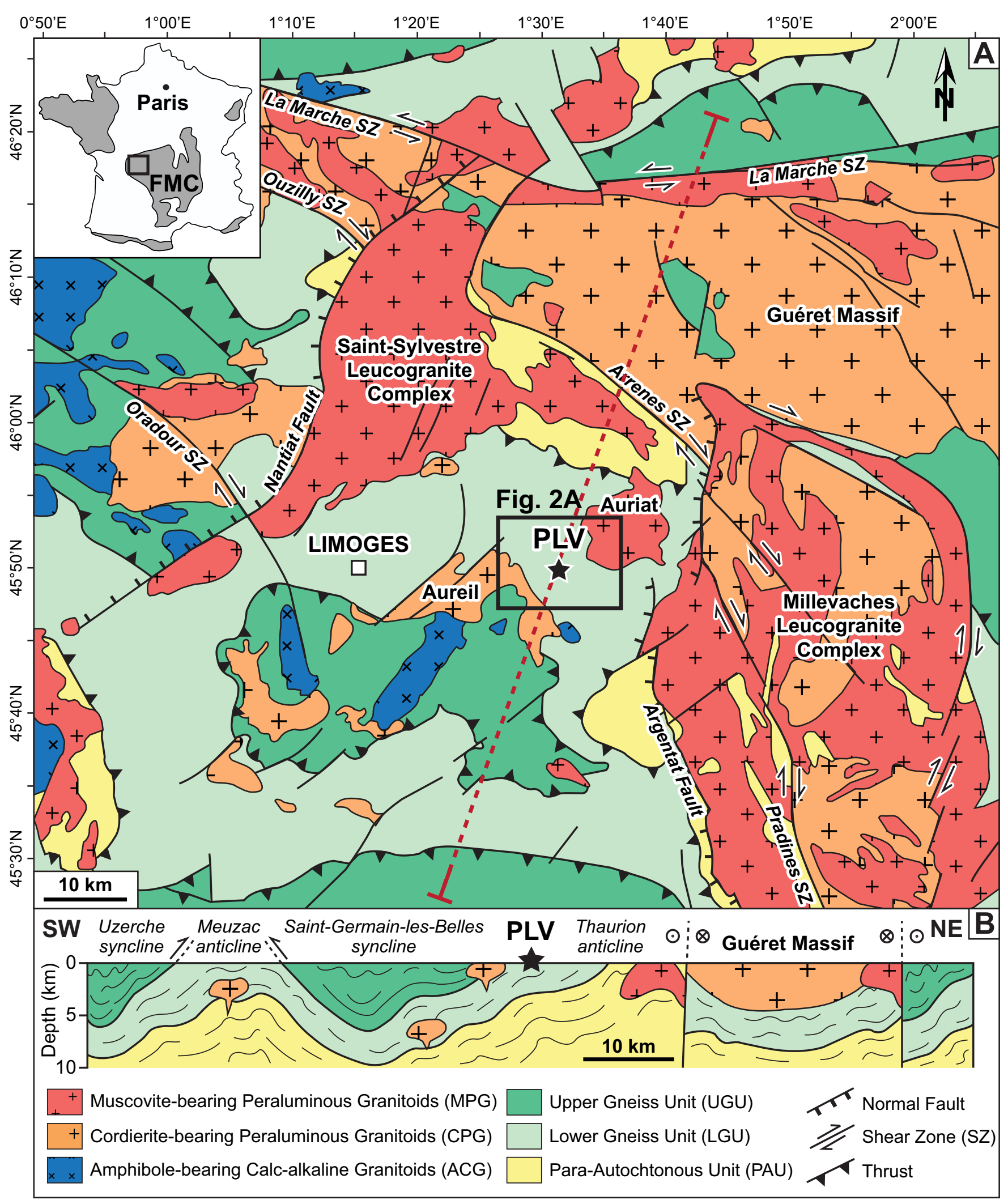

Fig. 1. (A) Geological setting and location of the Puy-les-Vignes (PLV) deposit in the northwestern French Massif Central (FMC). (B) Simplified geologic NE-SW cross-section through the northwestern FMC showing the stack of metamorphic nappes (modified from Lardeaux et al., 2014). The location of the cross-section is reported on Figure 1A (dashed red line). 


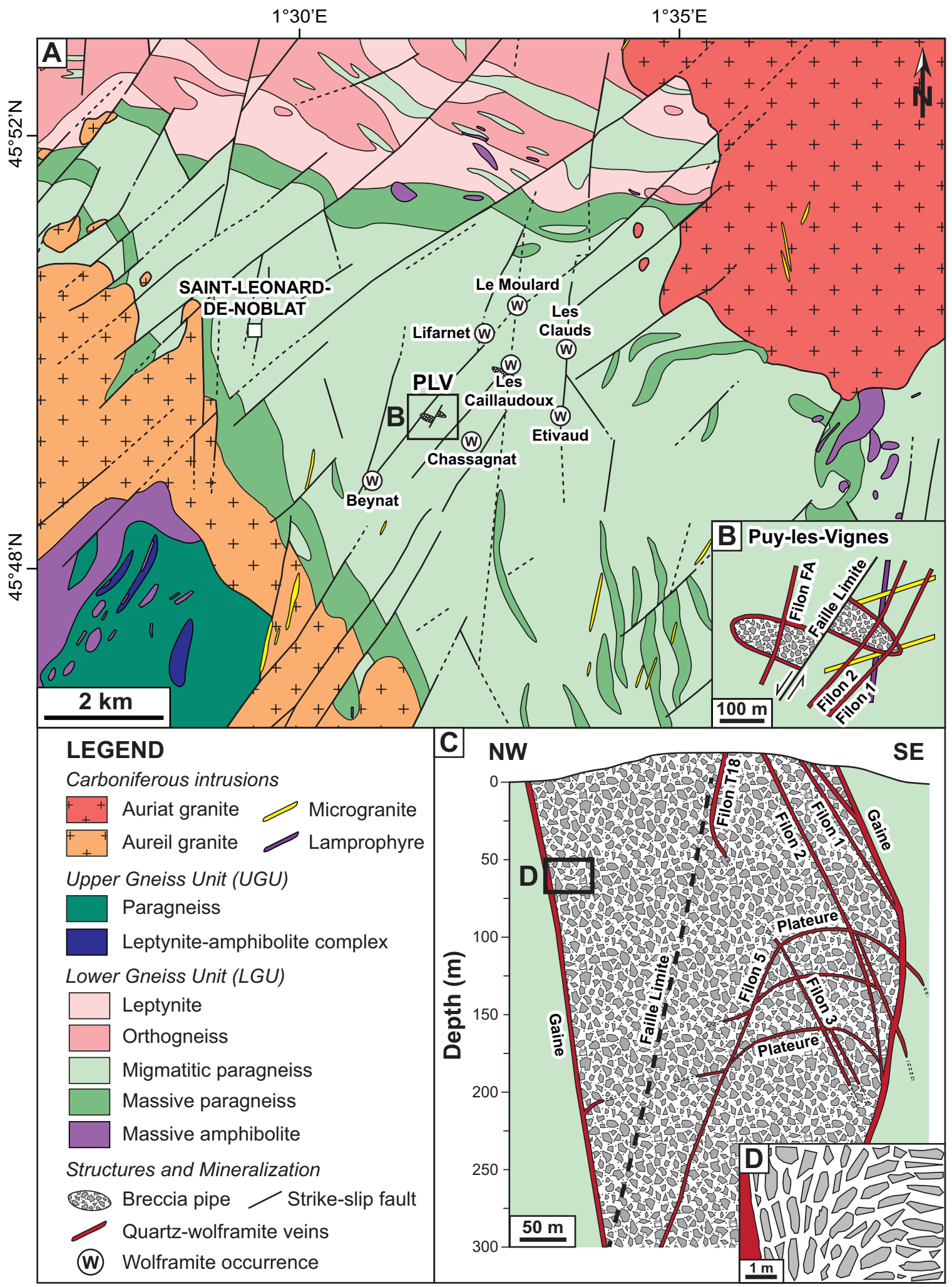

Fig. 2. Regional geological setting of the Puy-les-Vignes (PLV) deposit. (A) Geological map of the Puy-les-Vignes area and location of the surroundings W occurrences (modified from Chenevoy et al., 1984). (B) Close-up sketch of the breccia pipe structure at surface intersected by wolframite-bearing veins (modified from Weppe, 1951). (C) Interpretative cross-section through the Puy-les-Vignes breccia pipe projected along the NW-SE major axis (modified from Weppe, 1951, 1958). (D) Simplified sketch showing the apparent rotational movement of the clasts within the breccia pipe according to Weppe $(1951,1958)$. 
for discovering new $\mathrm{W}$ resources is significant a Puy-les-Vignes considering the number of wolframite occurrences in the district, that only half of the breccia pipe was mined, that the vertical extent of the deposit is unknown, and that the whole breccia body represents a potential low-grade ore.

According to Weppe $(1951,1958)$, the formation of the Puy-les-Vignes breccia pipe would result from three successive stages: (i) A first stage of hydraulic fracturing and mass collapse produced a matrix-supported breccia composed of polygenic and heterometric clasts of the country rocks (mainly gneisses) cemented by quartz constituting about $10 \%$ of the total volume of the breccia. Metric-size clasts have undergone syn-collapse rotation as suggested by the progressive tipping of gneissic blocks within the breccia where fragments adjacent to the pipe margins are subvertical and those towards the center are subhorizontal (Fig. 2D); (ii) A second collapse stage led to the formation of subvertical quartz-filled decollements ("gaine" and "croiseurs"), delimiting the borders of the breccia pipe with the country rocks, and quartz-filled planar-curved veins and dome structures ("plateures") dipping at low-angle $\left(<30^{\circ}\right)$ within the breccia. The contact between the breccia and the enclosing gneisses is sharp and consists of a $0.5-$ to-3-m thick quartz vein delimiting the southern and northern boundaries of the pipe; (iii) A third stage yielded the formation of a NE-trending network of subparallel quartz-wolframite-sulfide veins ("filons") dipping at high-angle $\left(>50^{\circ}\right)$ and crosscutting the entire breccia pipe and the host gneisses. These veins are about $400 \mathrm{~m}$ long with variable thickness of $0.2-1 \mathrm{~m}$ and contain most of the $\mathrm{W}$ mineralization with grades ranging from 0.2 to $2 \% \mathrm{WO}_{3}$ (Mouthier, 2005). The quartz-filled decollements at the breccia-country rock boundary and the quartz cementing the breccia also contain wolframite but at lower grades (Fig. 3D). The $\mathrm{W}$ mineralization is dated at $317.7 \pm 0.7 \mathrm{Ma}$ based on $\mathrm{U} / \mathrm{Pb}$ dating of wolframite from a mineralized vein (Harlaux et al., 2018a).

\section{Materials and analytical methods}

\subsection{Sampling}

The Puy-les-Vignes mine is closed since 1957 and the underground workings are no more accessible. Previous work from Alikouss (1993) was based on a few samples taken from the historical collection of $\mathrm{M}$. Weppe coming from the underground workings and from samples collected in mining dumps, which are less accessible today due to revegetalization. The present work relies on access to private collections of old mine workers (P. Medda, G. Pradeau) and to museum collections (Musée Minéralogique de l'École des Mines d'Alès, France, Collection P. Fitte) corresponding to samples coming directly from the underground mine when it was still operating. Information on the precise depth location and underground adit was available for some samples. Mining archives indicate that only ores from the Puy-les-Vignes mine were processed on site (Mouthier, 2005), thus excluding any risks of mixing with ores coming from other mines. Complementary samples for this study come from surface sampling of stripped terrains and trenches during recent site reworking and from a small outcrop of the breccia (Fig. 3). The latter is located at the margin of the eastern part of the breccia pipe close to a formerly mined quartz-wolframite vein ("filon 1") in proximity to the old mining headframe ("Puits
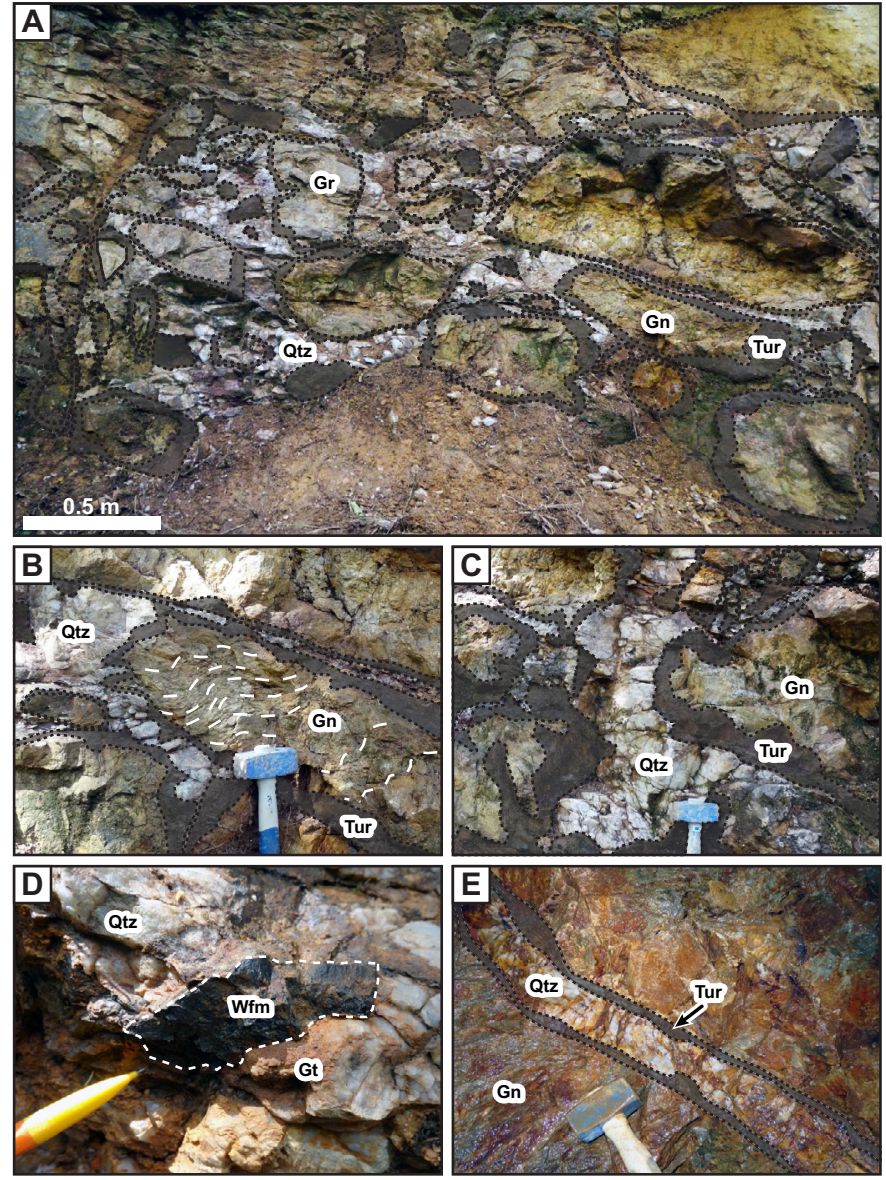

Fig. 3. Field relations of the Puy-les-Vignes breccia pipe. (A) Outcrop of the polygenic breccia composed of decimetric to metric clasts of altered gneisses (Gn) and granites (Gr) partially to completely tourmalinized. The clasts are angular to subangular in shape and are systematically rimmed by tourmaline (Tur) and cemented by quartz (Qtz). (B-C) Details of greisenized gneissic clasts showing relict foliation (white dashed lines) and an irregular tourmalinite aureole of variable thickness. (D) Wolframite (Wfm) disseminated within the quartz of the breccia and partially altered by goethite (Gt). (E) Wolframite-bearing quartz vein with tourmaline selvages crosscutting the St-Léonard-de-Noblat gneisses observed in an old underground adit at Lifarnet.

Girod"). An old underground adit of about $150 \mathrm{~m}$ in length cutting through the Saint-Léonard-de-Noblat gneisses and intersecting quartz-wolframite-sulfide-tourmaline veins was also studied at Lifarnet ( $<2 \mathrm{~km}$ north of Puy-les-Vignes). This diversified sampling offers a set of representative samples for the host rocks and mineralization from the Puy-les-Vignes deposit (Fig. 4).

\subsection{Petrography and geochemistry}

Mineralogical analyses were performed at GeoRessources, Université de Lorraine (Nancy, France), using an Olympus BX51 optical microscope and a JEOL J7600F scanning electron microscope (SEM) equipped with a SDD-type energy 

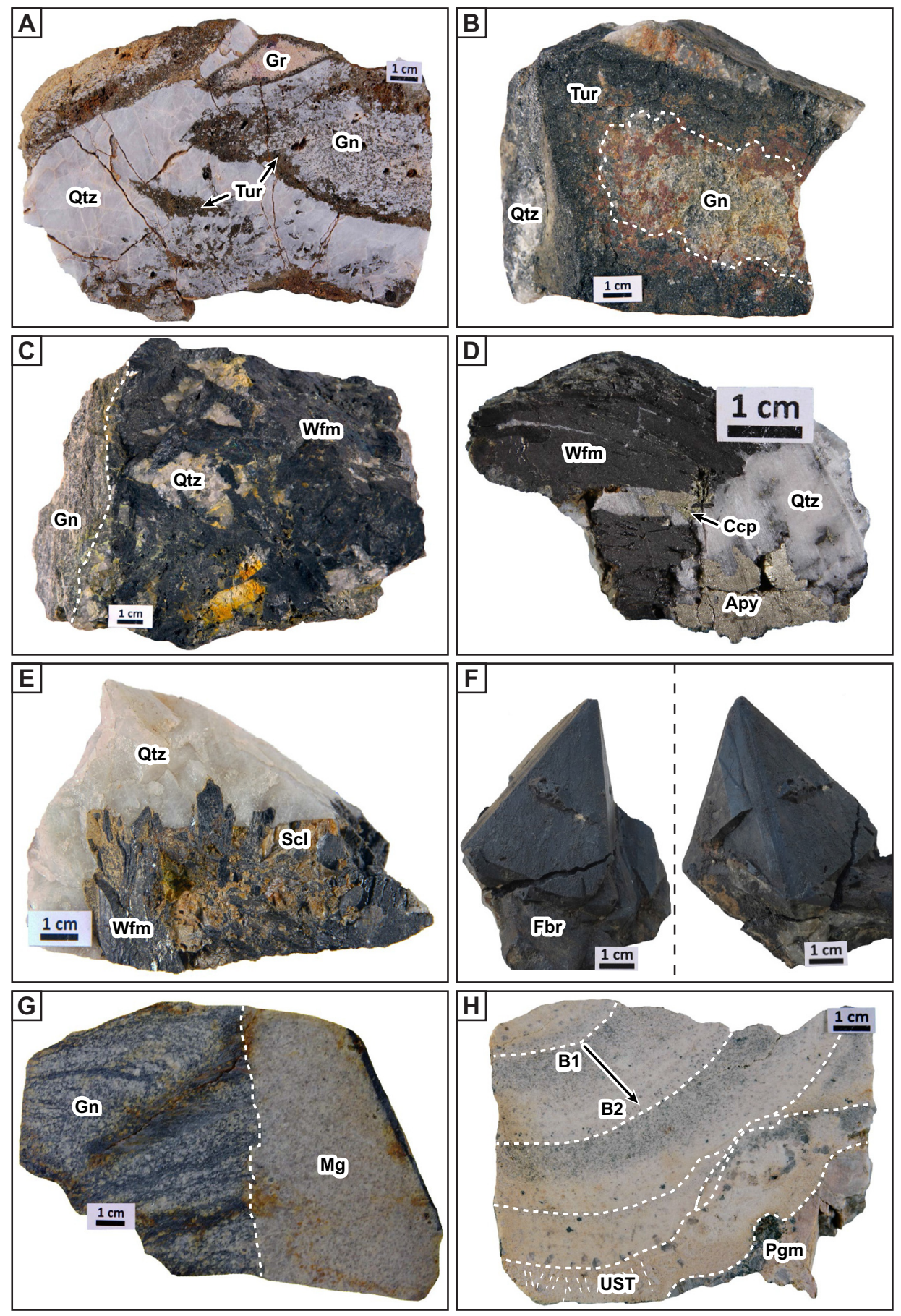

Fig. 4. Representative samples of host rocks and orebodies from the Puy-les-Vignes deposit. (A) Polygenic breccia constituting the main body of the pipe composed of angular to subangular clasts of greisenized gneisses $(\mathrm{Gn})$ and granites (Gr) rimmed by an aureole of tourmalinite and cemented by milky quartz (sample PLV-02-04). (B) Typical clast of greisenized gneiss rimmed by a cm-thick aureole of tourmalinite and cemented by quartz (sample PLV-7571). (C) Wolframite-bearing quartz vein crosscutting gneiss (sample PLV-7574). (D) Typical vein assemblage composed of quartz, wolframite and arsenopyrite with minor chalcopyrite (sample PLV-02-29). (E) Wolframite partially replaced by orange-brownish-colored scheelite in a quartz vein (sample PLV-3071). (F) Spectacular sample of centimetric ferberite pseudomorph after scheelite ("reinite"). (G) Microgranite dyke (Mg) crosscutting the foliation of biotite-sillimanite gneiss (sample PV-92-7). (H) Rare-metal granite (RMG) showing a magmatic layering composed of a repetitive sequence of quartz-albite-muscovite bands ("B1") evolving to albitequartz bands ("B2") (sample PLV-02-02). The last albite-quartz zone in the lower part of the sample shows unidirectional solidification texture (UST) preceding the transition to a granitic pegmatite (Pgm). Mineral abbreviations according to the IMA. 
dispersive X-ray spectrometer (EDS) coupled to an Oxford Wave wavelength dispersive X-ray spectrometer (WDS). Backscattered electron (BSE) images were acquired on carbon-coated polished thin sections with an acceleration voltage of $15 \mathrm{kV}$. Chemical compositions of Nb-Ta-W-Ti-Sn oxides were measured at GeoRessources using a CAMECA SX100 electron microprobe analyzer (EMPA) operated with a $20 \mathrm{kV}$ accelerating voltage, a $20 \mathrm{nA}$ beam current, and a $1 \mu \mathrm{m}$ beam diameter. The following standards and elements were analyzed using WDS spectrometers: hematite $(\mathrm{Fe} \mathrm{K} \alpha)$, $\mathrm{MnTiO}_{3}(\mathrm{Mn} \mathrm{K} \alpha$, Ti K $\alpha$ ), olivine $(\mathrm{Mg} \mathrm{K} \alpha)$, corundum (Al $\mathrm{K} \alpha$ ), albite ( $\mathrm{Si} \mathrm{K} \alpha, \mathrm{Na} \mathrm{K} \alpha$ ), Sc metal $(\mathrm{Sc} \mathrm{K} \alpha)$, chromite $(\mathrm{Cr}$ $\mathrm{K} \alpha), \mathrm{LiNbO}_{3}(\mathrm{Nb} \mathrm{L} \alpha), \mathrm{LiTaO}_{3}(\mathrm{Ta} \mathrm{L} \alpha$ ), scheelite (W L $\alpha$ ), cassiterite $(\mathrm{Sn} \mathrm{L} \alpha)$, uraninite $(\mathrm{U} \mathrm{M} \alpha)$, galena $(\mathrm{Pb} \mathrm{M} \alpha)$. Counting times were $10 \mathrm{~s}$ on element peaks and $5 \mathrm{~s}$ on background. Minor and trace elements in rutile were measured by laser ablation - inductively coupled plasma- mass spectrometry (LA-ICP-MS) at GeoRessources using an Agilent 7500c quadrupole ICP-MS coupled with a $193 \mathrm{~nm}$ GeoLas ArF Excimer laser (MicroLas, Göttingen, Germany). Laser ablation was performed on polished thin sections with a constant $5 \mathrm{~Hz}$ pulse frequency and a fluence of $7 \mathrm{~J} \mathrm{~cm}^{-2}$ using variable laser spot diameters between 32 and $60 \mu \mathrm{m}$. Helium was used as carrier gas to transport the laser-generated particles from the ablation cell to the ICP-MS and argon was added as an auxiliary gas via a flow adapter before the ICP torch. Typical flow rates of $0.5 \mathrm{~L} \mathrm{~min}^{-1}$ for He and $0.9 \mathrm{~L} \mathrm{~min}^{-1}$ for Ar were used. The certified reference material NIST SRM 610 (Jochum et al., 2011) was used as an external standard for calibration of all analyses and was analyzed twice at the beginning and at the end of each set of samples, following a bracketing standardization procedure. The reference material NIST SRM 612 was used as a control standard for the standardization. Calibration of the ICP-MS was optimized for highest sensitivity on an intermediate $\mathrm{m} / \mathrm{Q}$ range, while maintaining $\mathrm{Th} / \mathrm{U} \sim 1$ and $\mathrm{ThO}^{+} / \mathrm{Th}^{+}<0.5 \%$, as determined on NIST SRM 610. The following isotopes were measured with a dwell time of $20 \mathrm{~ms}$ for each: ${ }^{29} \mathrm{Si},{ }^{45} \mathrm{Sc},{ }^{47} \mathrm{Ti},{ }^{51} \mathrm{~V},{ }^{53} \mathrm{Cr}$, ${ }^{57} \mathrm{Fe},{ }^{60} \mathrm{Ni},{ }^{63} \mathrm{Cu},{ }^{66} \mathrm{Zn},{ }^{90} \mathrm{Zr},{ }^{93} \mathrm{Nb},{ }^{95} \mathrm{Mo},{ }^{118} \mathrm{Sn},{ }^{181} \mathrm{Ta}$, and ${ }^{182} \mathrm{~W}$. The total cycle time was of $332 \mathrm{~ms}$. Data reduction and absolute quantification of signals were performed using the software StalQuant (Fricker, 2012) developed at ETH Zürich (Switzerland) and the Ti content determined by EMPA. Limits of detection (LOD) were calculated using the $3 \sigma$ criterion of Longerich et al. (1996). Whole-rock geochemistry of selected samples was determined at the SARM-CNRS (Vandoeuvrelès-Nancy, France) following the procedure described by Carignan et al. (2001).

\section{3 $\mathrm{U} / \mathrm{Pb}$ geochronology}

$\mathrm{U} / \mathrm{Pb}$ dating of rutile was performed at the GeOHeLiS analytical platform (Géosciences Rennes/OSUR, University of Rennes, France) using an ESI NWR193UC Excimer laser system coupled to an Agilent 7700x quadrupole ICP-MS. The rutile grains were previously investigated by SEM and EMPA in order to select chemically homogeneous zones that lack microinclusions and alteration features. Laser ablation was performed on polished thin sections at repetition rate of $5 \mathrm{~Hz}$, a fluence of $8.6 \mathrm{~J} \mathrm{~cm}^{-2}$, and using spot diameters of 40 or $50 \mu \mathrm{m}$ depending on grain size. The ablated material was carried by $\mathrm{He}$ and then mixed with $\mathrm{N}_{2}$ and $\mathrm{Ar}$ (Paquette et al., 2014) before injection into the ICP torch equipped with a dual pumping system to enhance sensitivity. Typical gas flows of $0.75 \mathrm{~L} \mathrm{~min}^{-1}$ for $\mathrm{He}, 3 \mathrm{~mL} \mathrm{~min}^{-1}$ for $\mathrm{N}_{2}$ and $0.85 \mathrm{~L} \mathrm{~min}^{-1}$ for Ar were used. Tuning of the instrument and mass calibration were performed before the analytical session using the NIST SRM 612 reference material (Jochum et al., 2011) by monitoring the ${ }^{238} \mathrm{U}$ signal and minimizing the $\mathrm{ThO}^{+} / \mathrm{Th}^{+}$ ratio $<0.5 \%$. The signals of ${ }^{204} \mathrm{~Pb},{ }^{206} \mathrm{~Pb},{ }^{207} \mathrm{~Pb},{ }^{208} \mathrm{~Pb},{ }^{232} \mathrm{Th}$, and ${ }^{238} \mathrm{U}$ were measured with a dwell time of $10 \mathrm{~ms}(30 \mathrm{~ms}$ for ${ }^{207} \mathrm{~Pb}$ ). For each analysis, $20 \mathrm{~s}$ of background was integrated, followed by $60 \mathrm{~s}$ of laser-generated signal acquisition. Each analysis was separated by a $15 \mathrm{~s}$ delay of wash-out. Data were corrected for $\mathrm{U} / \mathrm{Pb}$ fractionation and for the mass bias by standard bracketing with repeated measurements of the R10 rutile (1090 Ma; Luvizotto et al., 2009) reference standard. The R19 rutile reference material $(489.5 \pm 0.9 \mathrm{Ma}$; Zack et al., 2011) was analyzed as a secondary standard to control the reproducibility and accuracy of the corrections and yielded an age of $492.9 \pm 4.4 \mathrm{Ma}(\mathrm{MSWD}=0.89, \mathrm{n}=13$ ). The $\mathrm{U} / \mathrm{Pb}$ isotopic analyses of the rutile standards are reported in Supplementary Table 1. Data reduction and age calculations were carried out with the GLITTER software package (Van Achterbergh et al., 2001). Analyses yielding non-radiogenic isotopic ratios were rejected. Data were plotted using ISOPLOT v.3.75 (Ludwig, 2008). Error propagation is by quadratic addition according to Horstwood et al. (2016). For more information on the analytical procedure, see Boutin et al. (2016) and Supplementary Table 1.

\section{$3.4{ }^{40} \mathrm{Ar} /{ }^{39} \mathrm{Ar}$ geochronology}

${ }^{40} \mathrm{Ar} /{ }^{39} \mathrm{Ar}$ analytical work was performed at the University of Manitoba (Canada) using a multi-collector Thermo Fisher Scientific ARGUS VI mass spectrometer, linked to a stainless steel Thermo Fisher Scientific extraction/purification line, Photon Machines (55 W) Fusions $10.6 \mathrm{CO}_{2}$ laser, and Photon Machines (Analyte Excite) $193 \mathrm{~nm}$ laser. Argon isotopes (from mass 40 to 37) were measured using Faraday detectors with low noise $10^{12} \Omega$ resistors and mass 36 was measured using a compact discrete dynode (CDD) detector. All specimens (samples and standards) were irradiated for $17 \mathrm{~h}$ in the Cadmium-lined, in-core CLICIT facility of the TRIGA reactor at the Oregon State University, USA. Standards of Fish Canyon sanidine (Kuiper et al., 2008) and GA1550 biotite (Spell and McDougall, 2003) were placed in a Cu sample tray, with a $\mathrm{KBr}$ cover slip, in a stainless-steel chamber with a differentially pumped $\mathrm{ZnS}$ viewport attached to a Thermo Fisher Scientific extraction/purification line and baked with an infrared lamp for $24 \mathrm{~h}$. Unknowns consist of discs of $5 \mathrm{~mm}$ in diameter and $\sim 150 \mu \mathrm{m}$ thick that were cut from thick polished section investigated by optical microscopy and SEM prior to ${ }^{40} \mathrm{Ar} /{ }^{39} \mathrm{Ar}$ analyses. The discs were mounted using a ceramic adhesive (PELCO) on a quartz slide placed in a stainless-steel chamber with a sapphire viewport attached to the same stainless-steel high vacuum extraction system as the $\mathrm{CO}_{2}$ laser, and baked with an infrared lamp for $48 \mathrm{~h}$. For this study, a raster size of about $100 \mu \mathrm{m} \times 100 \mu \mathrm{m}$ was used and ablation pits were excavated to an estimated depth of $50 \mu \mathrm{m}$. Five argon 
isotopes were measured simultaneously over a period of 6 minutes. Measured isotope abundances were corrected for extraction-line blanks, which were determined before every sample analysis. Line blanks in both the Excimer and $\mathrm{CO}_{2}$ system averaged $\sim 3 \mathrm{fA}$ for mass 40 and $\sim 0.013 \mathrm{fA}$ for mass 36. Detector intercalibration (IC) between the different faraday cups was monitored (in Qtegra) every four days by peak hopping ${ }^{40} \mathrm{Ar}$. Calculated values are ICH1: 1.0000, ICAX: 1.0745, ICL1: 1.0637, and ICL2: 1.0534, with an error of $\sim 0.2 \%$. The intercalibration factor between $\mathrm{H} 1$ and the CDD was measured using 70 air aliquots interspersed with the unknowns resulting in ICCDD: $1.0081 \pm 0.0002$ per amu. A value of 295.5 was used for the atmospheric ${ }^{40} \mathrm{Ar} /{ }^{36} \mathrm{Ar}$ ratio (Steiger and Jäger, 1977) for the purposes of routine measurement of mass spectrometer discrimination using air aliquots, and correction for atmospheric argon in the ${ }^{40} \mathrm{Ar} /{ }^{39} \mathrm{Ar}$ age calculation. Corrections are made for neutron-induced ${ }^{40} \mathrm{Ar}$ from potassium, ${ }^{39} \mathrm{Ar}$ and ${ }^{36} \mathrm{Ar}$ from calcium, and ${ }^{36} \mathrm{Ar}$ from chlorine (Renne et al., 1998; Renne and Norman, 2001). Data collection, reduction, error propagation and age calculation were performed using the MassSpec software (v.8.091; Deino, 2013). The decay constants used were those recommended by Steiger and Jäger (1977). Data were plotted using DensityPlotter (Vermeesch, 2012), and uncertainties in tables and text are quoted at the $1 \sigma$ and $2 \sigma$ level, respectively.

\subsection{Fluid inclusion analysis}

Fluid inclusions were studied using double-polished 150-200 $\mu \mathrm{m}$ thick sections of quartz-wolframite vein samples. Petrographic and microthermometric analyses of quartzhosted fluid inclusions were performed at GeoRessources on a THMS 600 Linkam heating-cooling stage mounted on an Olympus BX-51 microscope. The stage was calibrated at $-56.6^{\circ} \mathrm{C}, 0.0^{\circ} \mathrm{C}$, and $374.1^{\circ} \mathrm{C}$ using pure $\mathrm{H}_{2} \mathrm{O}$ and $\mathrm{H}_{2} \mathrm{O}-\mathrm{CO}_{2}$ synthetic fluid inclusion standards. Petrography and microthermometry of wolframite-hosted fluid inclusions were carried out at the University of Geneva (Switzerland) using a Linkam FTIR 600 stage mounted on an Olympus BH-51 microscope equipped with an Olympus XM-10 near-infrared (NIR) camera (Ortelli et al., 2018). Calibration of the heatingcooling stage was performed regularly using SynFlinc standards at $-56.6^{\circ} \mathrm{C}, 0.0{ }^{\circ} \mathrm{C}$, and $374.1^{\circ} \mathrm{C}$ (Sterner and Bodnar, 1984). The visible light absorbed by opaque minerals is partially converted into heat in proportion to the opacity and this could potentially preclude accurate microthermometric measurements (Moritz, 2006). To avoid this problem, a voltmeter was connected directly to the lamp of the microscope to control the power of the incident light following the procedure described by Ortelli et al. (2018). Sample heating is not high enough to affect microthermometric measurements if a $90 \%$ closed diaphragm, a condenser at 0.3 , and a power of $<4 \mathrm{~V}$ depending on the transparency of the different zones of the crystals are used (Casanova et al., 2018). The salinities, densities, and bulk compositions of $\mathrm{CO}_{2}$-bearing fluid inclusions were calculated based on the clathrate melting temperature (Tm clat) and homogenization temperature of the $\mathrm{CO}_{2}$ phase $\left(\mathrm{Th} \mathrm{CO}_{2}\right.$ ) using the Q2 program developed by Bakker (1997) and the equations of state from Thiéry et al. (1994) and Duan et al. (1996). Isochores were calculated using the ISOC program (Bakker, 2003) based on the equations of state from Bakker (1999). For $\mathrm{H}_{2} \mathrm{O}-\mathrm{NaCl}$ fluid inclusions, the salinities, densities, and isochores were calculated based on the ice-melting temperature (Tm ice) and total homogenization temperature (Th) using the HokieFlincs $\mathrm{H} 2 \mathrm{O}-\mathrm{NaCl}$ program (Steele-MacInnis et al., 2012). Raman spectroscopy analyses of fluid inclusions were carried out at GeoRessources using a Horiba Jobin-Yvon LabRAM HR spectrometer equipped with a $1800 \mathrm{~g} \mathrm{~mm}^{-1}$ grating and an Edge filter. The excitation beam is provided by a Stabilite $2017 \mathrm{Ar}^{+}$laser (Spectra Physics, Newport Corporation) at $514.532 \mathrm{~nm}$ and a power of $400 \mathrm{~mW}$ focused on the sample using $\times 50$ and $\times 100$ objectives mounted on an Olympus BX-40 optical microscope. The signal-to-noise ratio was optimized, ideally lower than $1 \%$, by adjusting the acquisition time and accumulation number. Gas compositions of fluid inclusions were measured at room temperature using a $500 \mu \mathrm{m}$ confocal hole aperture and a $100 \mu \mathrm{m}$ slit aperture. The relative proportions of the gas species $(\mathrm{mol} \%)$ were calculated using the peak area, acquisition time, and the specific Raman scattering cross-sections (Burke, 2001).

\section{Paragenetic sequence of the Puy-les- Vignes deposit}

Petrographic observations from the outcrop- to the micrometer-scale, completing previous descriptions (Weppe, 1951, 1958; Alikouss, 1993; Harlaux et al., 2015a; Harlaux, 2016), allow proposing a detailed paragenetic sequence of the Puy-les-Vignes deposit divided into six main stages (Fig. 5).

\subsection{Stage I: Early hydrothermal alteration and brecciation}

Greisenization of the country rocks (mainly gneisses) is the earliest hydrothermal alteration episode identified at Puy-lesVignes. It corresponds to dissolution of primary feldspar and biotite in the Saint-Léonard-de-Noblat paragneisses and precipitation of secondary quartz, muscovite, and tourmaline ("Tur 1" of Harlaux et al., 2019; Fig. 6A). The foliation is partly preserved within the gneissic clasts (Figs. 3B and 6A) and relics of biotite and feldspar remain in unaltered parts of the clasts, suggesting that greisenization was diffuse and limited to structural discontinuities. Greisenization (stage Ia) was followed by hydraulic brecciation and collapse of the host rocks resulting in a clast-supported tourmaline crackle breccia (stage Ib). The clasts of gneisses and granites are angular to subangular in shape, centimetric to plurimetric in size, and lack granulometric classification (Fig. 3A). They are surrounded by an irregular rim of tourmalinite (tourmaline \pm quartz) of variable thickness, ranging from a few millimeters to several centimeters (Figs. 3B, 3C, 4A and 4B), and up to complete tourmalinization of the clasts. Hydrothermal alteration of the clasts results from two successive steps: (i) chloritization of residual biotite associated with formation of $\mathrm{Fe}-\mathrm{W}$-rich rutile (Fig. 7A), monazite, xenotime, and zircon; (ii) tourmalinization of the clasts rims forming dense aggregates of prismatic tourmaline ("Tur 2" of Harlaux et al., 2019) cemented by quartz (Fig. 6B). 


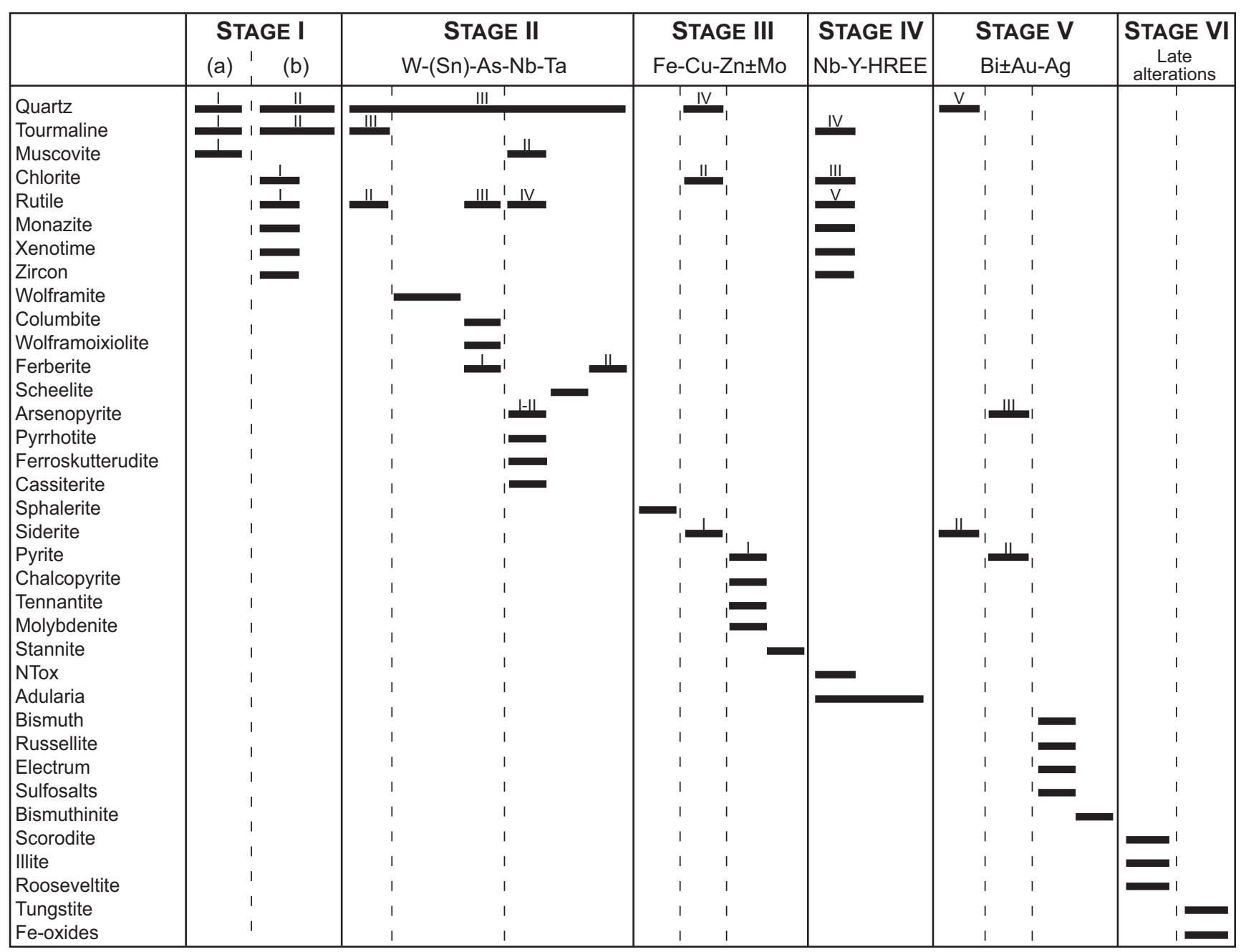

Fig. 5. Paragenetic sequence of the Puy-les-Vignes deposit showing the succession of six main hydrothermal stages. Dash lines represent minor episodes of hydraulic fracturing. See text for details.

\subsection{Stage II: W-(Sn)-As-Nb-Ta mineralization}

Hydraulic brecciation and fluid-assisted reopening of the tourmaline crackle breccia produced the quartz-supported breccia pipe and wolframite-bearing quartz veins. The contact between the tourmaline-bordered clasts and the quartz cement is sharp and crack-seal textures are common (Figs. 4A and 4B). Syn-collapse rotation of the clasts occurred prior or concomitantly to quartz deposition as indicated by variable orientation of the foliation within gneissic clasts. Quartz crystals of up to $20 \mathrm{~cm}$-length are locally found in geodic cavities within the breccia matrix. At the microscopic scale, quartz is composed of millimetric polycrystalline aggregates showing evidence of ductile deformation (undulose extinction, lamellar deformation) and dynamic recrystallization (bulging and subgrain rotation; Fig. 6C). Besides quartz, wolframite and arsenopyrite are the main minerals in the mineralized veins (Figs. 4C and 4D). Wolframite is euhedral ranging from millimetric to pluri-centimetric in size, exceptionally up to decimetric, and grew directly onto the clast rims. Most wolframite is $\mathrm{Fe}$-dominated $\quad(\mathrm{Fe} /(\mathrm{Fe}+\mathrm{Mn})=0.80-0.86$;
Harlaux et al., 2018b) but is locally replaced by a variety of wolframite having almost pure ferberitic composition (ferberite-1; $\mathrm{Fe} /(\mathrm{Fe}+\mathrm{Mn})>0.95)$ along microcracks and crystal borders (Figs. 6D and 7B). Arsenopyrite is the main sulfide in the quartz veins and is associated with minor pyrrhotite and crosscuts wolframite (Fig. 6E). Most arsenopyrite is characterized by a weight ratio of $\mathrm{As} / \mathrm{S}=2.5$ but an early variety of arsenopyrite containing about $4.5 \mathrm{wt} . \%$ Co and $1 \mathrm{wt} . \% \mathrm{Ni}$ with a weight ratio of $\mathrm{As} / \mathrm{S}=3$ was identified by EDS analyses (Fig. 7C). Minor cassiterite is intergrown with arsenopyrite (Fig. 7D) and rare Cr-rich phengites ("mariposite") are also found in association with arsenopyrite. Accessory minerals of tourmaline, muscovite, and $\mathrm{Nb}-\mathrm{Ta}-\mathrm{W}$ oxides are also present in the quartz veins. Prismatic acicular tourmaline ("Tur 3" of Harlaux et al., 2019) occurs perpendicularly on clast rims and as disseminations in quartz and is also locally intergrown with wolframite. Muscovite consists of millimetric flakes disseminated in quartz or overgrown on wolframite, and occasionally shows kink-band deformation (Fig. 6C). Accessory Nb-Ta-W oxide minerals associated with the stage II include (i) $\mathrm{Nb}-\mathrm{Ta}-$ rich rutile disseminated in quartz (Fig. 7E), (ii) $\mathrm{Fe}-\mathrm{Nb}$-rich 

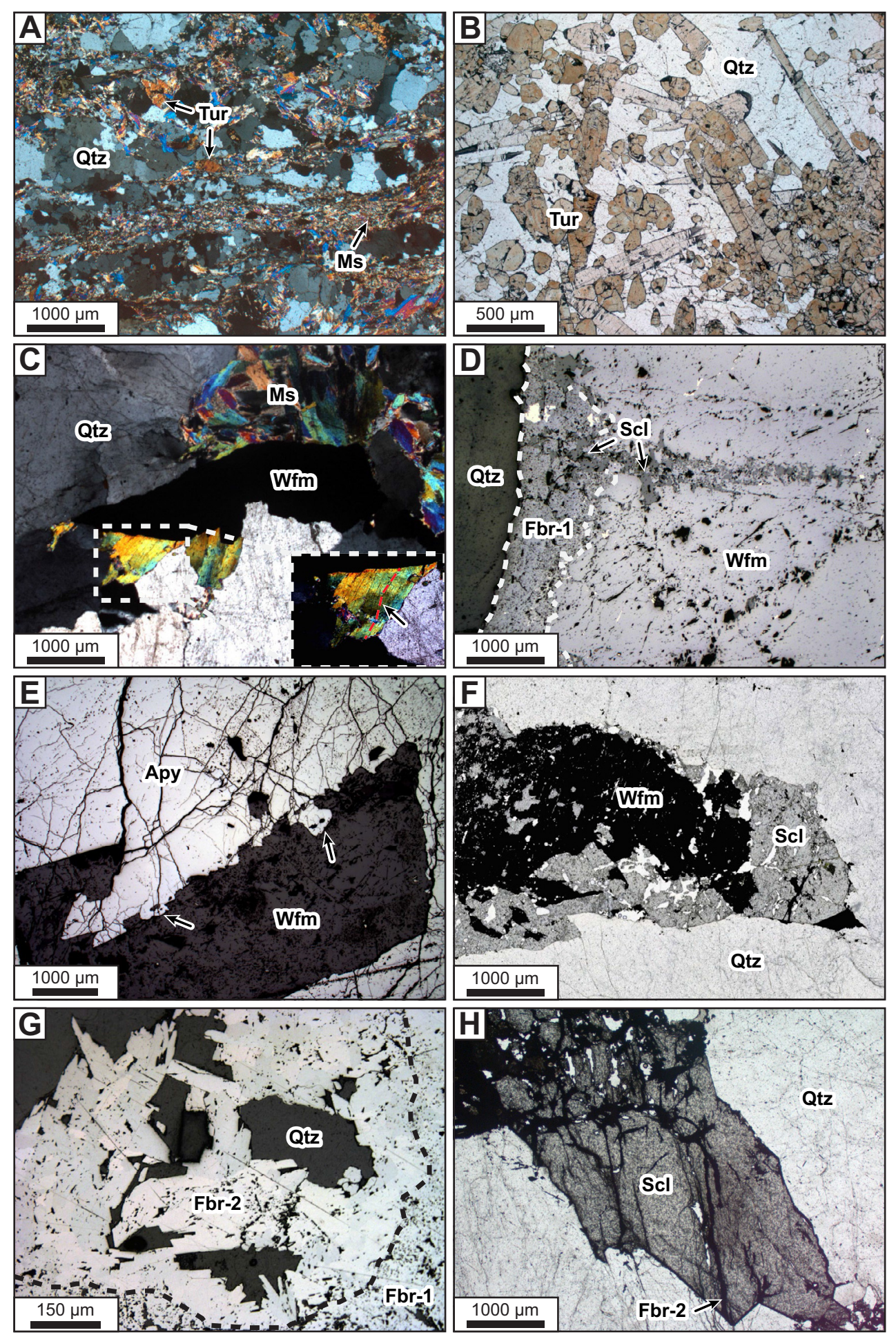

Fig. 6. Photomicrographs of mineral assemblages for paragenetic stages I to VI of the Puy-les-Vignes deposit. (A) Greisenized gneiss composed of secondary quartz, muscovite and tourmaline with partially preserved foliation (stage Ia; crosspolarized transmitted light, sample PLV-02-01a). (B) Tourmalinite rim on a gneissic clast composed of prismatic tourmaline aggregates cemented by macrocrystalline quartz (stage Ib; planepolarized transmitted light, sample PLV-02-01a). (C) Subeuhedral wolframite grain overgrown by muscovite showing kink-band deformation (stage II; crosspolarized transmitted light, sample PLV-02-03). (D) Wolframite partially replaced by ferberite-1 along crystal borders and crosscut by scheelite veinlets (stage II; reflected light, sample PLV-7597a). (E) Wolframite partially replaced by arsenopyrite showing dissolution features (stage II; reflected light, sample PLV-02-28b). (F) Scheelite replacing wolframite and showing dissolution textures (stage II; plane-polarized transmitted light, sample PLV-7597b). (G) Polycrystalline aggregates of randomly-oriented fibrous ferberite-2 crystals ("reinite") within ferberite-1 (stage II; reflected light, sample PLV-02-11). (H) Ferberite-2 pseudomorph after scheelite ("reinite") (stage II; plane-polarized transmitted light, sample PLV-02-26). 

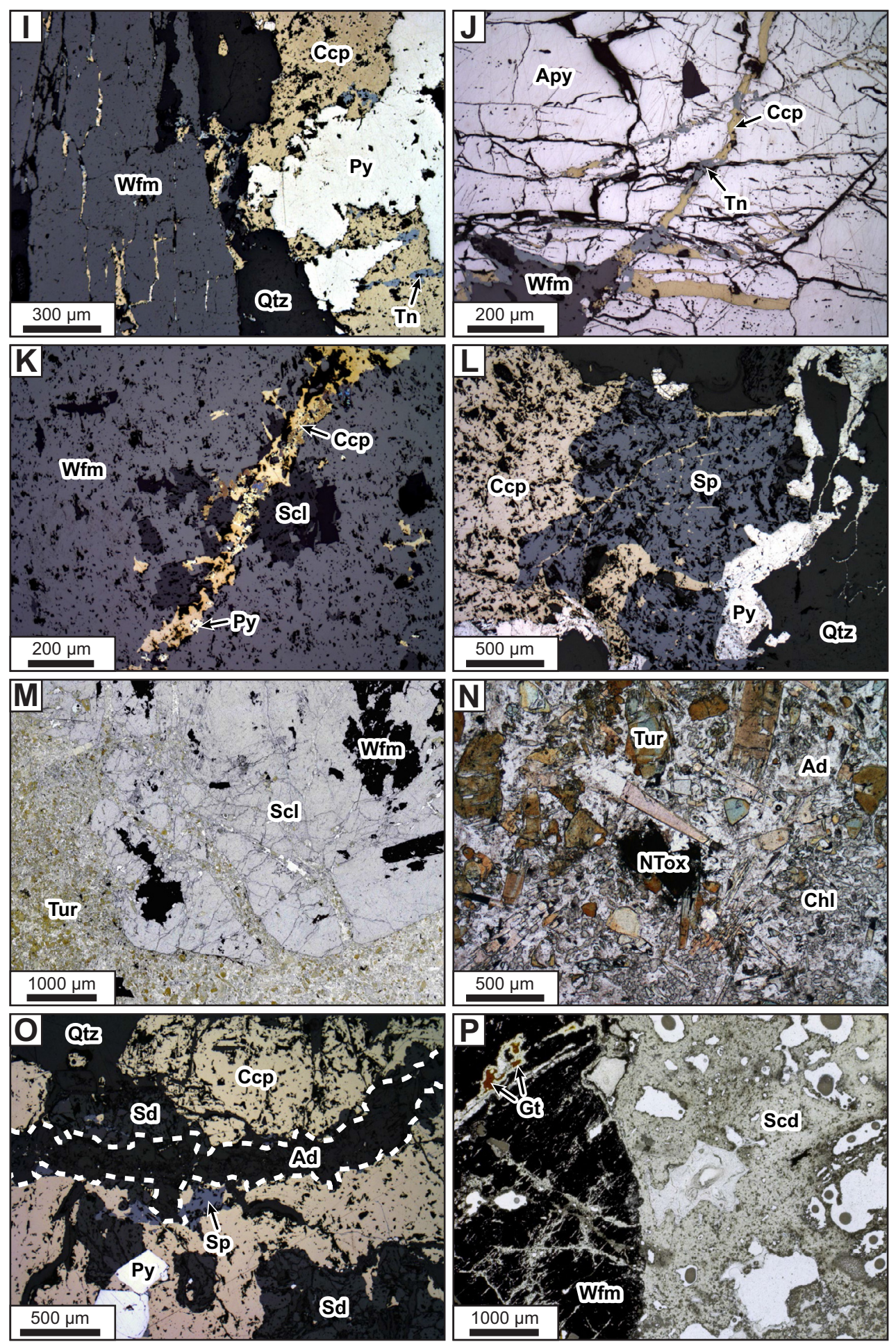

Fig. 6. (continued) (I) Base metal sulfide association (pyrite, chalcopyrite and tennantite) overprinting wolframite (stage III; reflected light, sample PLV-02-29). (J) Arsenopyrite crosscut by a chalcopyrite-tennantite veinlet (stage III; reflected light, sample PLV-7574a). (K) Pyritechalcopyrite veinlet crosscutting wolframite and scheelite (stage III; reflected light, sample PV-2a). (L) Sphalerite crosscut by chalcopyrite and pyrite association (stage III; reflected light, sample PV-3). (M) Scheelite containing relicts of wolframite and fragmented by a tourmalineadularia crackle breccia (stage IV; plane-polarized transmitted light, sample PLV-02-13a). (N) Detail of the microbreccia composed of clasts of tourmaline, vermicular chlorite, and Nb-Ti-Y-HREE-W-U oxides (NTox) within an adularia matrix (stage IV; plane-polarized transmitted light, sample PLV-02-13a). (O) Adularia veinlet crosscutting quartz, siderite and chalcopyrite association (stage IV; reflected light, sample PV2b). (P) Wolframite overprinted by scorodite and goethite resulting from complete dissolution of arsenopyrite (stage VI; plane-polarized transmitted light, sample PLV-02-17). Mineral abbreviations according to the IMA. 

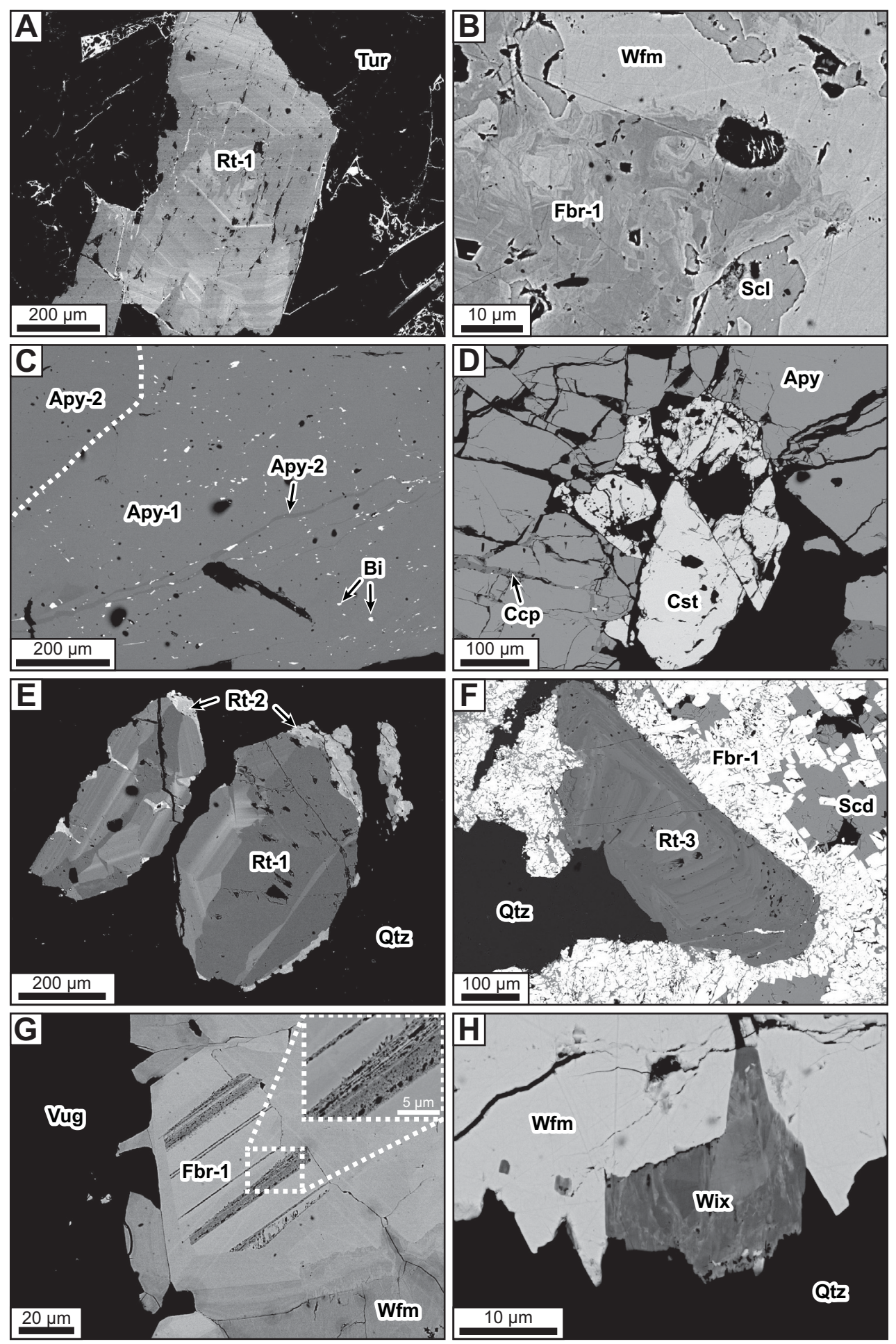

Fig. 7. Backscattered electron images of mineral assemblages for paragenetic stages I to VI of the Puy-les-Vignes deposit. (A) Subeuhedral Fe-W-rutile (Rt-1) intergrown with tourmaline on a greisenized granitic clast (stage I; sample PLV-02-04a). (B) Wolframite partially altered to ferberite-1 and scheelite showing patchy texture at microscopic scale (stage II; sample PLV-7597a). (C) Arsenopyrite-1 (stage II) cut by arsenopyrite-2 veinlets and hosting numerous tiny inclusions of native bismuth (stage V; sample PLV-7597a). (D) Cassiterite intergrown with arsenopyrite (stage II) crosscut by chalcopyrite veinlets (stage III; sample PV-2a). (E) Subeuhedral Fe-W-rutile (Rt-1) overgrown by Nb-Tarich rutile (Rt-2) disseminated in a quartz-wolframite vein (stage II; sample PLV-7574a). Fe-W-rutile shows a homogeneous core (dark grey) with W-rich sectors (light grey) having growth zoning. (F) Fe-Nb-rich rutile (Rt-3) within ferberite-1 showing growth banding (stage II; sample PLV-02-17). (G) Ta-Nb-rich ferberite-1 in a dissolution microvug within wolframite showing Ta-Nb-rich growth bands at the micrometer scale (stage II; sample PV-3). (H) Wolframoixiolite in a quartz-filled veinlet crosscutting wolframite (stage II; sample PV-5a). 

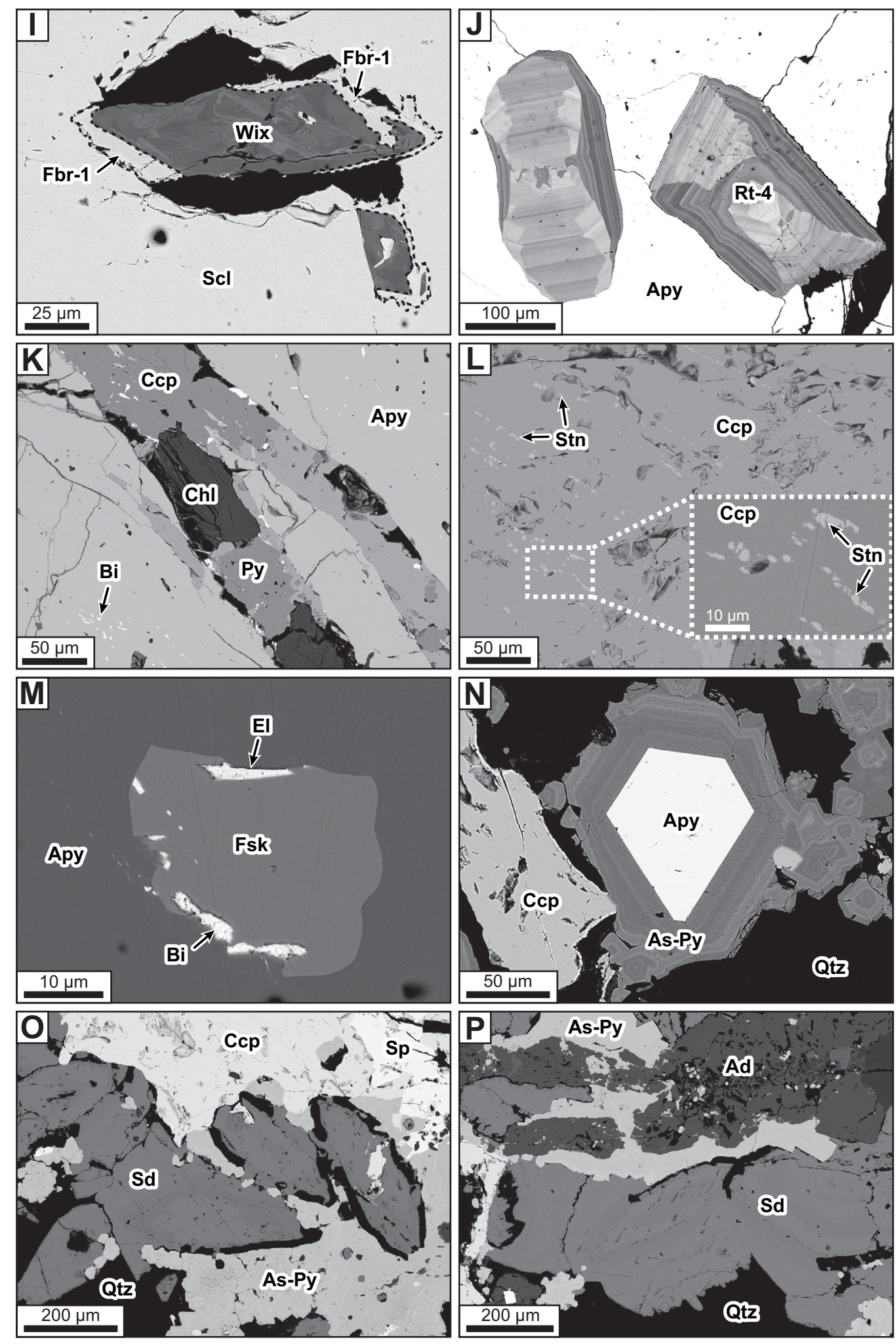

Fig. 7. (continued) (I) Wolframoixiolite rimmed and partially replaced by ferberite-1 within scheelite (stage II; sample PLV-02-13b). (J) Subeuhedral grains of $\mathrm{Cr}-\mathrm{Nb}-\mathrm{W}$-rich rutile (Rt-4) disseminated within arsenopyrite (stage III; sample PLV-02-28b). (K) Arsenopyrite crosscut by chalcopyrite-pyrite-chlorite veinlets (stage III) and overprinted by native Bi microinclusions (stage V; sample PV-3). (L) Exsolution trails of stannite within chalcopyrite (stage III; sample PV-2a). (M) Association of native Bi and electrum (Au-Ag) in microvugs infilling arsenopyrite and Fe-skutterudite (stage V; sample PLV-7597a). (N) Colloform As-rich pyrite overgrown on euhedral arsenopyrite-3 and chalcopyrite (stage V; sample PV-2b). (O) As-rich pyrite and siderite (stage V) overgrown on sphalerite and chalcopyrite from stage III (sample PV-2b). (P) As-rich pyrite and siderite crosscutting an adularia veinlet (stage V; sample PV-2b). Mineral abbreviations according to the IMA. 
rutile disseminated within ferberite-1 (Fig. 7F), (iii) $\mathrm{Ta}-\mathrm{Nb}-$ rich ferberite (1.6 wt.\% Ta, 0.4 wt. $\% \mathrm{Nb}$, and 0.8 wt.\% P; EDS analyses) in dissolution microvugs within wolframite (Fig. 7G), (iv) a variety of $\mathrm{W}$-rich ixiolite (hereafter named wolframoixiolite) in quartz-filled veinlets cutting wolframite (Fig. $7 \mathrm{H}$ ) and as disseminations overgrown by ferberite-1 (Fig. 7I), and (v) $\mathrm{Cr}-\mathrm{Nb}-\mathrm{W}$-rich rutile disseminated within arsenopyrite (Fig. 7J) together with inclusions of $\mathrm{Fe}$ skutterudite ([Fe, $\left.\mathrm{Co}, \mathrm{Ni}] \mathrm{As}_{3}\right)$, wolframite, xenotime, and monazite. Scheelite is late relative to the $\mathrm{Nb}-\mathrm{Ta}-\mathrm{W}$ oxides and occurs as centimetric bipyramidal euhedral grains having orange-brownish-colors (Fig. 4E). Scheelite partly replaces wolframite and ferberite-1 (Fig. 6F), crosscuts arsenopyrite along veinlets, and shows undulose extinction similar to quartz. A third generation of wolframite of ferberitic composition (ferberite-2; $\mathrm{Fe} /(\mathrm{Fe}+\mathrm{Mn})>0.95)$ occurs as pseudomorphs after ferberite- 1 and scheelite and forms aggregates of randomly oriented fibrous crystals (Figs. 6G and $6 \mathrm{H}$ ). Locally, ferberite-2 forms octahedral crystals of pluri-centimetric size in quartz geodic cavities (Fig. 4F), corresponding to the "reinite" described by Weppe $(1951,1958)$.

\subsection{Stage III: $\mathrm{Fe}-\mathrm{Cu}-\mathrm{Zn} \pm$ Mo mineralization}

Base metal sulfide assemblages, including pyrite, chalcopyrite, and sphalerite overprint the mineral paragenesis of stages I and II. Pyrite and chalcopyrite are volumetrically the most important minerals of this stage. They crosscut wolframite and arsenopyrite (Figs. 6I-6K) and are coeval with the deposition of quartz and chlorite (Fig. 7K). Sphalerite is early relative to pyrite and chalcopyrite (Fig. 6L) and contains up to $2 \mathrm{wt} . \% \mathrm{Cd}$, as determined by EDS analyses. Minor tennantite (identified by EDS) is associated with chalcopyrite (Figs. 6I and 6J). Molybdenite is thought to be coeval with chalcopyrite but its paragenetic position remains uncertain. Stannite is late and occurs locally as exsolution trails within chalcopyrite (Fig. 7L), as revealed by EDS analyses. Deposition of sulfides is associated with recrystallization of quartz along the crystal borders of wolframite and arsenopyrite. The sulfide assemblage and associated quartz are not deformed, thus suggesting that stage III postdates the main ductile deformation episode.

\subsection{Stage IV: Nb-Y-HREE mineralization}

This stage is recorded by a millimeter-scale hydrothermal crackle breccia composed of clasts of tourmaline ("Tur 4" of Harlaux et al., 2019) and vermicular chlorite cemented by adularia and overprinting a deformed quartz-wolframitescheelite-sulfide vein (Fig. 6M). Adularia is not deformed indicating that the brecciation episode occurred after the main ductile deformation that affected the deposit. The crackle breccia contains a series of accessory minerals disseminated within adularia, including monazite, xenotime, zircon, $\mathrm{Nb}-\mathrm{Fe}-\mathrm{W}$-rich rutile, and $\mathrm{Nb}-\mathrm{Ti}-\mathrm{Y}-\mathrm{HREE}-\mathrm{W}-\mathrm{U}$ oxides referred to as NTox (Fig. 6N). The latter minerals were studied in detail by Harlaux et al. (2015b) and consist of subeuhedral grains $(10-400 \mu \mathrm{m}$ in size) having complex internal textures and elevated concentrations of $\mathrm{Nb}, \mathrm{Ti}, \mathrm{Y}$, HREE, and W. This mineral paragenesis is characterized by a
$\mathrm{P}, \mathrm{Y}, \mathrm{HREE}, \mathrm{Nb}>\mathrm{Ta}$, Ti, $\mathrm{Zr}$, and $\mathrm{U}$ geochemical signature, which has been interpreted by Harlaux et al. (2015b) to result from rare-metal-bearing hydrothermal fluids derived from an unknown peralkaline magmatic body at depth.

\subsection{Stage $\mathrm{V}: \mathrm{Bi} \pm \mathrm{Au}-\mathrm{Ag}$ mineralization}

A volumetrically minor assemblage of native bismuth, bismuthinite $\left(\mathrm{Bi}_{2} \mathrm{~S}_{3}\right), \mathrm{Bi}-\mathrm{Ag}-\mathrm{Se}-\mathrm{Te}$ sulfosalts, and electrum (ca. 78 wt.\% Au and 22 wt.\% Ag) fills microcavities and microcracks overprinting quartz, wolframite and arsenopyrite from stage II, base metal sulfides from stage III, and adularia from stage IV (Figs. 7I-7M). Accessory Bi-Ag-Se-Te sulfosalt minerals include hedleyite $\left(\mathrm{Bi}_{7} \mathrm{Te}_{3}\right)$ and sztrokayite $\left(\mathrm{Bi}_{3} \mathrm{TeS}_{2}\right)$. Quartz, siderite, arsenopyrite, and colloform As-rich pyrite (1-10 wt.\% As) precede the deposition of the Bi minerals (Figs. $6 \mathrm{O}$ and $7 \mathrm{~N}-7 \mathrm{P}$ ). Russellite $\left(\mathrm{Bi}_{2} \mathrm{WO}_{6}\right)$ locally occurs as pseudomorph after ferberite at the contact with native bismuth.

\subsection{Stage VI: Late hydrothermal and supergene alterations}

Late hydrothermal fluid circulations are responsible for alteration of arsenopyrite to scorodite $\left(\mathrm{FeAsO}_{4} \cdot 2 \mathrm{H}_{2} \mathrm{O}\right)$ and other arsenates such as pharmacosiderite, carminite, and beudantite. Scorodite is usually greenish in color, has a skeletal porous texture, and occurs as pseudomorph after arsenopyrite or as veinlets crosscutting wolframite and chalcopyrite (Fig. 6P). Minor illite and rooseveltite $\left(\mathrm{BiAsO}_{4}\right)$ are associated with scorodite, indicating the remobilization of bismuth during alteration of arsenopyrite. Supergene weathering of the orebody resulted in the partial destabilization of wolframite and residual sulfides in secondary minerals such as tungstite $\left(\mathrm{WO}_{3} \cdot \mathrm{H}_{2} \mathrm{O}\right)$, colloform goethite, and Fe-oxides-hydroxides.

\section{Petrography and geochemistry of granitic rocks}

\subsection{Microgranite dykes}

Microgranite dykes crosscut the host paragneisses and are fragmented within the breccia and cut by tourmaline veins, indicating an emplacement prior to the early hydrothermal alteration and brecciation stages. The least altered sample of microgranite (sample PV-92-7), collected at surface, is a finegrained rock composed of quartz, K-feldspar, plagioclase and muscovite (Figs. 4G and 8A). Quartz shows undulose extinction while feldspars are partly sericitized. The microgranite composition is strongly peraluminous $(\mathrm{A} / \mathrm{CNK}=1.54)$ and plots along the fractionation trend of evolved leucogranites, rare-metal granites (RMG), and rare-metal pegmatites (RMP) from the northwestern FMC (Fig. 9; Tab. 1). Its trace element composition overlaps those of muscovite-bearing peraluminous granitoids from the northwest FMC and is characterized by low contents of $\mathrm{Sr}(95 \mathrm{ppm})$, Th $(0.5 \mathrm{ppm})$, $\mathrm{Zr}(22 \mathrm{ppm}), \mathrm{Hf}(0.9 \mathrm{ppm})$, and $\mathrm{Pb}$ (5.8 ppm), and high contents of Rb (156 ppm), W (9.7 ppm) and Sn (41 ppm), compared to the upper continental crust (Fig. 10A). The REE contents are low $(11 \mathrm{ppm})$ and show a relatively flat spectrum $(\mathrm{La} / \mathrm{Yb}=1.38)$ with 

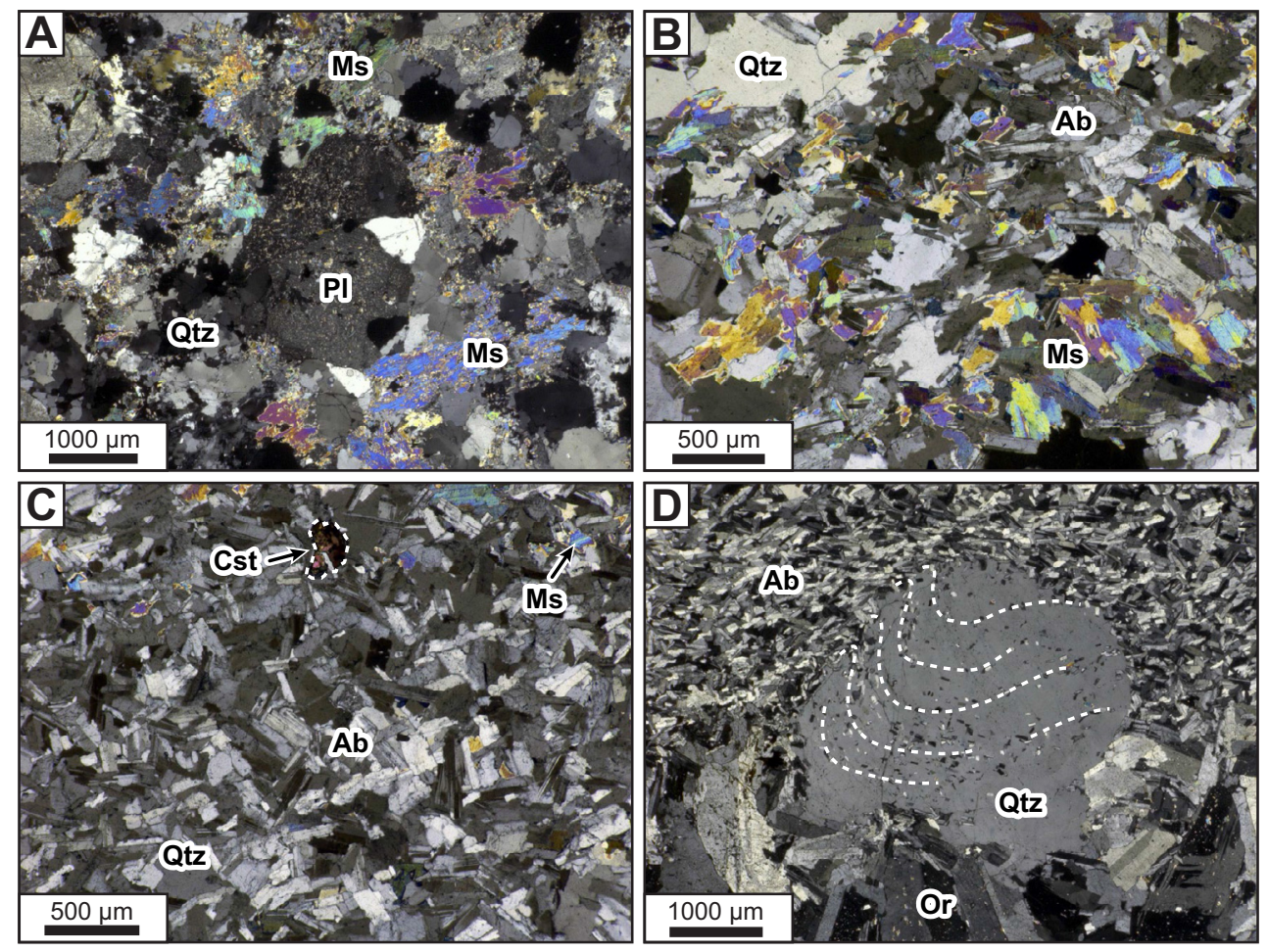

Fig. 8. Photomicrographs of granitic rocks from the Puy-les-Vignes deposit. (A) Microgranite dyke composed of quartz, plagioclase and muscovite showing sericitic alteration (crosspolarized transmitted light, sample PV-92-7). (B) Quartz-albite-muscovite zone within the RMG (crosspolarized transmitted light, sample PLV-02-02). (C) Albite-quartz zone within the RMG containing disseminated cassiterite (crosspolarized transmitted light, sample PLV-02-02). (D) Globular "snowball" quartz phenocryst containing poikilitic inclusions of rotated albite laths (white dashed lines) in the RMG (crosspolarized transmitted light, sample PLV-02-02). Mineral abbreviations according to the IMA.

a positive $\mathrm{Eu}$ anomaly $\left(\mathrm{Eu} / \mathrm{Eu}^{*}=1.66\right)$, which differs from the regional leucogranites (Fig. 10C). A strongly altered sample of microgranite (sample PV-92-5), also collected at surface, shows higher contents of $\mathrm{Fe}_{2} \mathrm{O}_{3}(2.9$ vs. 0.5 wt.\%) and $\mathrm{K}_{2} \mathrm{O}$ (4.3 vs. $\left.2.5 \mathrm{wt} . \%\right)$ and lower contents of $\mathrm{SiO}_{2}$ (75.2 vs. 78 wt.\%) and $\mathrm{Na}_{2} \mathrm{O}(0.2$ vs. 3.6 wt.\%) compared to the unaltered precursor. The trace element composition is similar to the least altered microgranite (Figs. 10A-10C), except for W (30 ppm), Sn (98 ppm), Bi (34 ppm), As (3540 ppm), and $\mathrm{Cu}(246 \mathrm{ppm})$ reflecting the effect of hydrothermal alteration.

\subsection{Granitic clasts}

The granitic clasts within the breccia are strongly greisenized and tourmalinized, indicating that the granite emplacement preceded the sequence of hydrothermal events. Two samples of strongly altered granitic clasts were collected at surface (samples PLV-02-10 and PLV-13-02). These rocks are dominantly composed of secondary quartz and muscovite that replaced the primary feldspars. The altered granitic clasts have strongly peraluminous compositions $(\mathrm{A} / \mathrm{CNK}=3.00-3.02)$ that plot along greisenization trend in the geochemical diagrams together with the strongly altered microgranite sample (Fig. 9; Tab. 1). Their trace element compositions partly overlap those of muscovite-bearing peraluminous granitoids from the northwestern FMC (Figs. 10A-10C). The REE spectra of the altered granites show a fractionated pattern $(\mathrm{La} / \mathrm{Yb}=1.74-6.36)$ with negative Eu anomalies $\left(\mathrm{Eu} / \mathrm{Eu}^{*}=0.44-0.68\right)$. Expectedly, these altered granitic rocks have elevated concentrations of $\mathrm{W}(40$ $97 \mathrm{ppm})$, Sn (56-89 ppm), As (2235-2275 ppm), Bi (26$28 \mathrm{ppm})$, and $\mathrm{Cu}(71-301 \mathrm{ppm})$ as a result of hydrothermal alteration by mineralizing fluids.

\subsection{Rare-metal granite}

A unique sample of RMG coming from the Puy-les-Vignes mine has been studied (sample PLV-02-02). The location of this granite as well as the relations with the breccia are unknown, but it is certain that this sample was collected in the old underground workings. The RMG is a fine-grained leucocratic rock showing a magmatic layering, which consists of a repetitive sequence of quartz-albite-muscovite band ("B1" on Figs. $4 \mathrm{H}$ and $8 \mathrm{~B}$ ) progressively evolving to albite-quartz band ("B2" on Figs. 4H and 8C). The transition between the two zones is marked by a progressively decreasing grain size from $500-1000 \mu \mathrm{m}$ on average in the quartz-albite-muscovite band to $100-200 \mu \mathrm{m}$ in the albite-quartz band. Quartz consists of xenomorphic globular phenocrysts containing poikilitic inclusions of albite laths in a typical "snowball" helicitic texture (Fig. 8D) while the granitic groundmass is characteristic of fractionated albitic cumulates. There is no evidence of post-magmatic deformation and hydrothermal alteration, thus suggesting that the RMG emplaced after the main episode of ductile deformation postdating the paragenetic stage II. Muscovites contain elevated $\mathrm{Si} / \mathrm{Al}$ ratios (1.12-1.97, $\mathrm{avg}=1.32)$ and high contents of $\mathrm{F}(2.3-8.5 \mathrm{wt} . \%$, avg $=4.2 \mathrm{wt} . \%)$, 

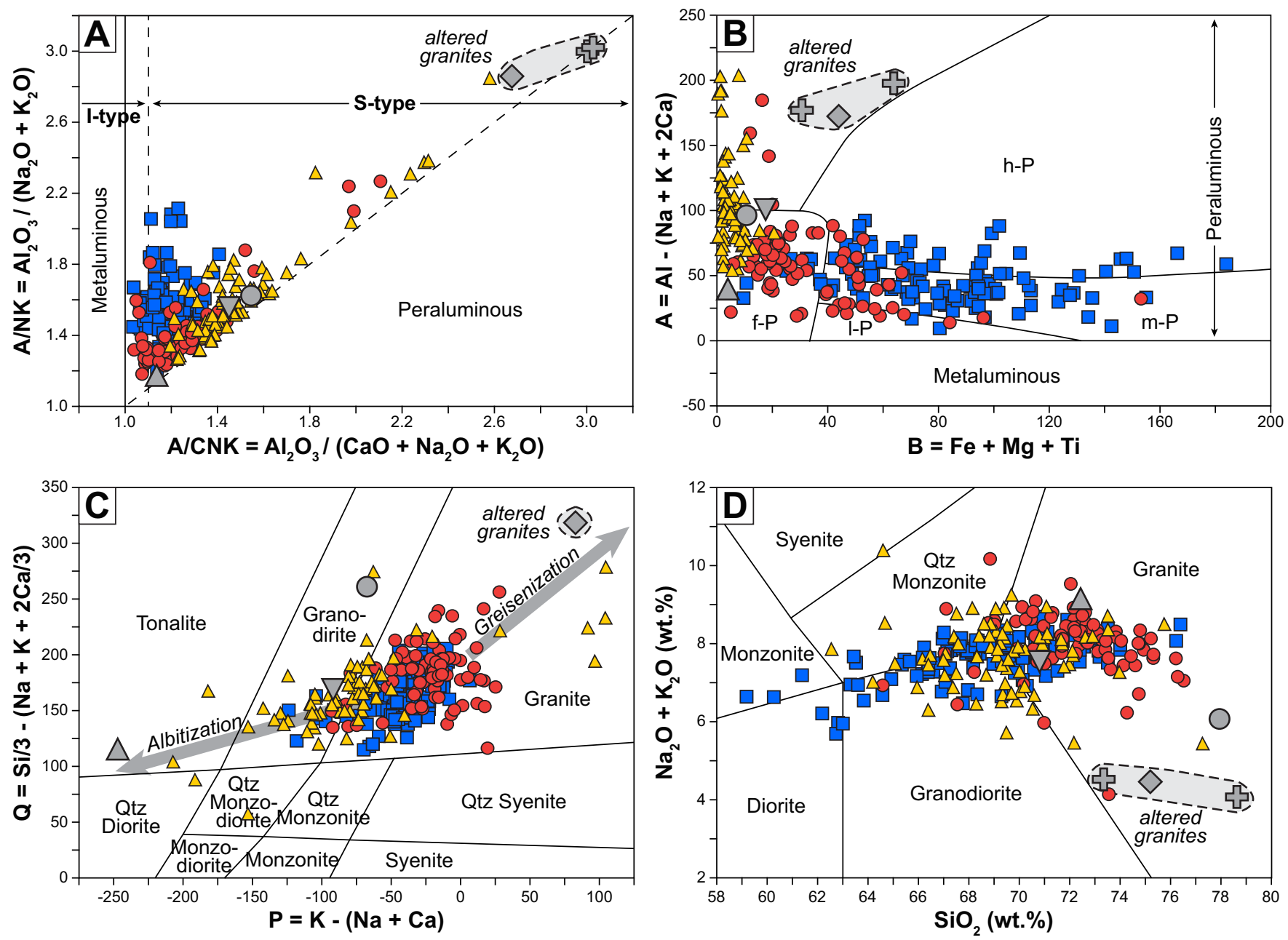

\begin{tabular}{|l|c|}
\hline Granites from Northwestern FMC: & Granites from Puy-les-Vignes: \\
$\begin{array}{l}\Delta \text { Rare-metal granites/pegmatites } \\
\text { Muscovite-bearing peraluminous }\end{array}$ & Rare-metal granite: $\triangle$ PLV-02-02a (Qtz-Ab zone) \\
$\begin{array}{l}\text { granitoids (St-Sylvestre-type) } \\
\text { Cordierite-bearing peraluminous }\end{array}$ & Microgranite dyke: $\bigcirc$ PV-92-02b (Qtz-Ab-Ms zone) \\
$\begin{array}{l}\text { Coranitoids (Guéret-type) } \\
\text { graltered) }\end{array}$ & $\diamond$ PV-92-5 (strongly altered) \\
\hline
\end{tabular}

Fig. 9. Major element compositions of granitic rocks from the Puy-les-Vignes deposit compared to the main peraluminous granitoids from the northwestern French Massif Central (FMC). (A) Alumina saturation diagram representing the molar ratio $\mathrm{A} / \mathrm{NK}=\mathrm{Al}_{2} \mathrm{O}_{3} /\left(\mathrm{Na}_{2} \mathrm{O}+\mathrm{K}_{2} \mathrm{O}\right)$ as function of the molar ratio $\mathrm{A} / \mathrm{CNK}=\mathrm{Al}_{2} \mathrm{O}_{3} /\left(\mathrm{CaO}+\mathrm{Na}_{2} \mathrm{O}+\mathrm{K}_{2} \mathrm{O}\right.$. (B) B-A diagram representing the differentiation index $\mathrm{B}=\mathrm{Fe}+\mathrm{Mg}+\mathrm{Ti}$ as function of the peraluminous index $\mathrm{A}=\mathrm{Al}-(\mathrm{Na}+\mathrm{K}+2 \mathrm{Ca})$ expressed in millications (after Debon and Le Fort, 1983). The peraluminous granite fields of Villaseca et al. (1998) represent highly peraluminous granitoids (h-P), moderately peraluminous granitoids (m-P), low peraluminous granitoids (1-P), and highly felsic peraluminous granitoids (f-P). (C) $\mathrm{P}-\mathrm{Q}$ diagram representing the relative proportion of feldspar $\mathrm{P}=\mathrm{K}-$ $(\mathrm{Na}+\mathrm{Ca})$ as function of the quartz content $\mathrm{Q}=\mathrm{Si} / 3-(\mathrm{Na}+\mathrm{K}+2 \mathrm{Ca} / 3)$ expressed in millications (after Debon and Le Fort, 1983). (D) Total alkali-silica (TAS) diagram representing the $\mathrm{Na}_{2} \mathrm{O}+\mathrm{K}_{2} \mathrm{O}$ vs. $\mathrm{SiO}_{2}$ content (after Le Bas et al., 1986). Whole-rock compositions of the granitic rocks are reported in Table 1. Data sources: rare-metal granites and pegmatites: Aubert (1969), Mourey (1985), Cuney et al. (1992), Raimbault et al. (1995), Raimbault (1998), Raimbault and Burnol (1998); muscovite-bearing peraluminous granitoids: Gauthier (1973), Burnol (1974), Arniaud et al. (1984), Soufi (1988), Leger et al. (1990), Downes et al. (1997), Solgadi et al. (2007), Moyen et al. (2017), Villaros and Pichavant (2019); cordierite-bearing peraluminous granitoids: Downes and Duthou (1988), Williamson et al. (1996), Downes et al. (1997), Cartannaz (2005), Solgadi et al. (2007), Couzinié (2017), Moyen et al. (2017). 

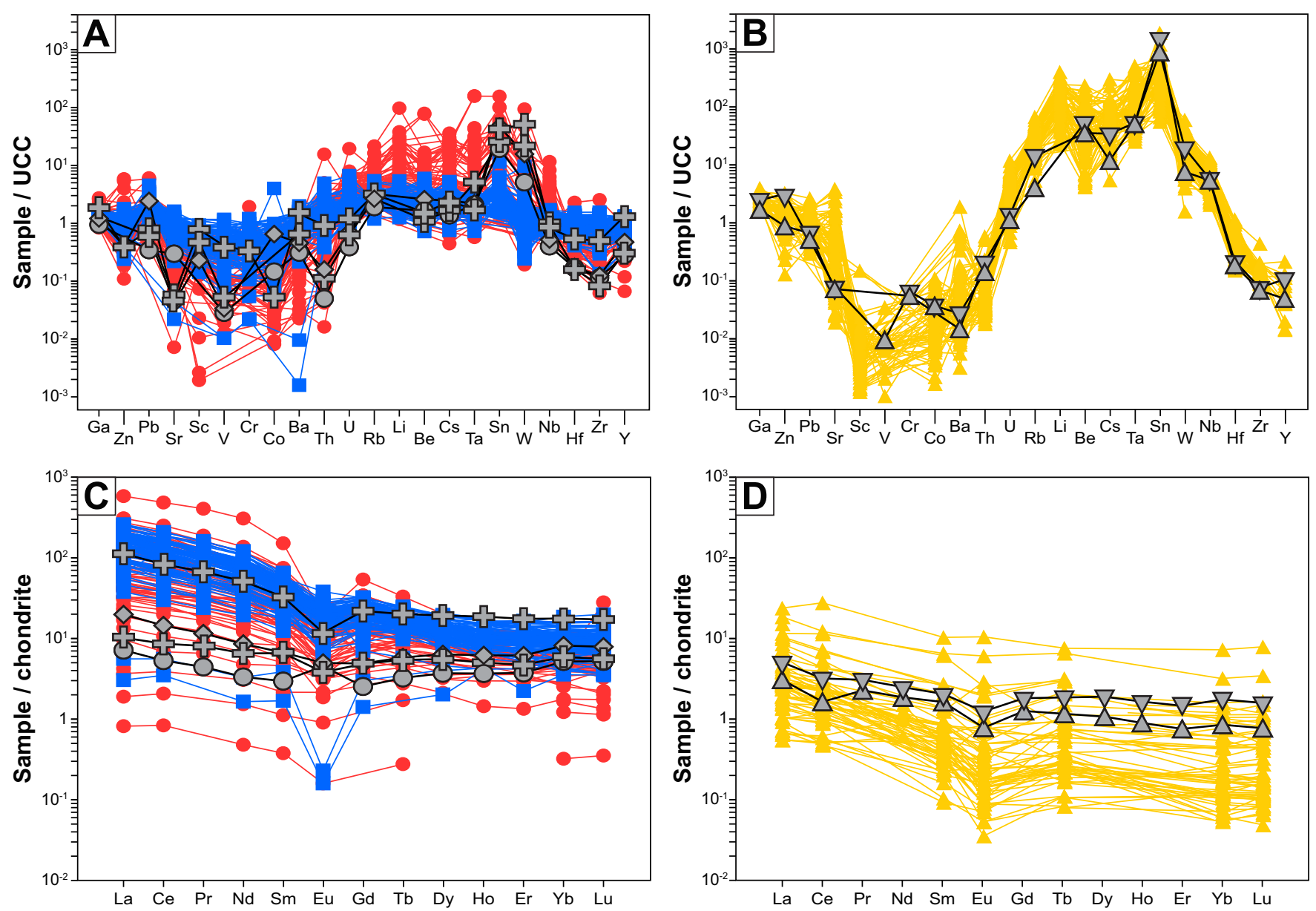

\begin{tabular}{|c|c|}
\hline Granites from Northwestern FMC: & Granites from Puy-les-Vignes: \\
$\begin{array}{c}\Delta \text { Rare-metal granites/pegmatites } \\
\text { O Muscovite-bearing peraluminous } \\
\text { granitoids (St-Sylvestre-type) }\end{array}$ & Rare-metal granite: $\triangle$ PLV-02-02a (Qtz-Ab zone) \\
$\begin{array}{c}\nabla \text { PLV-02-02b (Qtz-Ab-Ms zone) } \\
\begin{array}{c}\text { Cordierite-bearing peraluminous } \\
\text { granitoids (Guéret-type) }\end{array}\end{array}$ & $\begin{array}{c}\text { Microgranite dyke: } \mathrm{O} \text { PV-92-7 (weakly altered) } \\
\diamond \text { PV-92-5 (strongly altered) }\end{array}$ \\
\hline
\end{tabular}

Fig. 10. Trace element compositions of granitic rocks from the Puy-les-Vignes deposit compared to the main peraluminous granitoids from the northwestern French Massif Central (FMC). (A-B) Multi-element diagrams normalized by the upper continental crust (UCC) values from Rudnick and Gao (2003). (C-D) Rare earth element diagrams normalized by chondrite values from McDonough and Sun (1995). Whole-rock compositions of the granitic rocks are reported in Table 1. Data were compiled from the same sources as Figure 9.

as determined by EDS analyses. Accessory minerals include apatite, cassiterite, and columbite-tantalite that are disseminated in the albite-quartz bands. No magmatic zircons and monazite were found. The lower part of the sample shows unidirectional solidification textures (UST) composed of perpendicularly oriented K-feldspar phenocrysts relative to the magmatic layering. The albite-quartz band (referred as PLV-02-02a) and the quartz-albite-muscovite band (referred as PLV-02-02b) have been analyzed separately for wholerock geochemistry. The RMG has a strongly peraluminous composition $(\mathrm{A} / \mathrm{CNK}=1.13-1.45)$ that overlaps the fractionation trend of P-rich RMG-RMP from the FMC (Fig. 9; Tab. 1). The trace element composition shares many similarities with other RMG-RMP from the northwestern FMC, including depletion $(<25 \mathrm{ppm})$ in $\mathrm{Sr}, \mathrm{Sc}, \mathrm{V}, \mathrm{Cr}, \mathrm{Co}, \mathrm{Ba}, \mathrm{Hf}$, Th, and $\mathrm{Zr}$, and enrichment in $\mathrm{P}$ (1833-2357 ppm), $\mathrm{Rb}$ (329-1151 ppm) and Cs (58-170 ppm) compared to the upper continental crust (Fig. 10B). The rare-metal concentrations are notably elevated for $\mathrm{Nb}(65-69 \mathrm{ppm}), \mathrm{Ta}(46-47 \mathrm{ppm}), \mathrm{W}$ (14-37 ppm), Sn (853-3044 ppm), and Be (74-113 ppm). The REE contents are low $(4.0-6.5 \mathrm{ppm})$ with a flat pattern $(\mathrm{La} / \mathrm{Yb}=2.9-3.6)$ and negative $\mathrm{Ce}$ and $\mathrm{Eu}$ anomalies $\left(\mathrm{Ce} / \mathrm{Ce}^{*}=0.62-0.81, \mathrm{Eu} / \mathrm{Eu}^{*}=\right.$ 0.55-0.64), similar to other P-rich RMG-RMP from the FMC (Fig. 10D). Additionally, the studied sample has low ratios of $\mathrm{Zr} /$ $\mathrm{Hf}(12.7-13.2)$ and $\mathrm{Nb} / \mathrm{Ta}(1.41-1.45)$ typical of peraluminous P-rich RMG (Ballouard et al., 2016). 
M. Harlaux et al: BSGF 2021, 192, 33

Table 1. Major and trace element compositions of granitic rocks from the Puy-les-Vignes deposit.

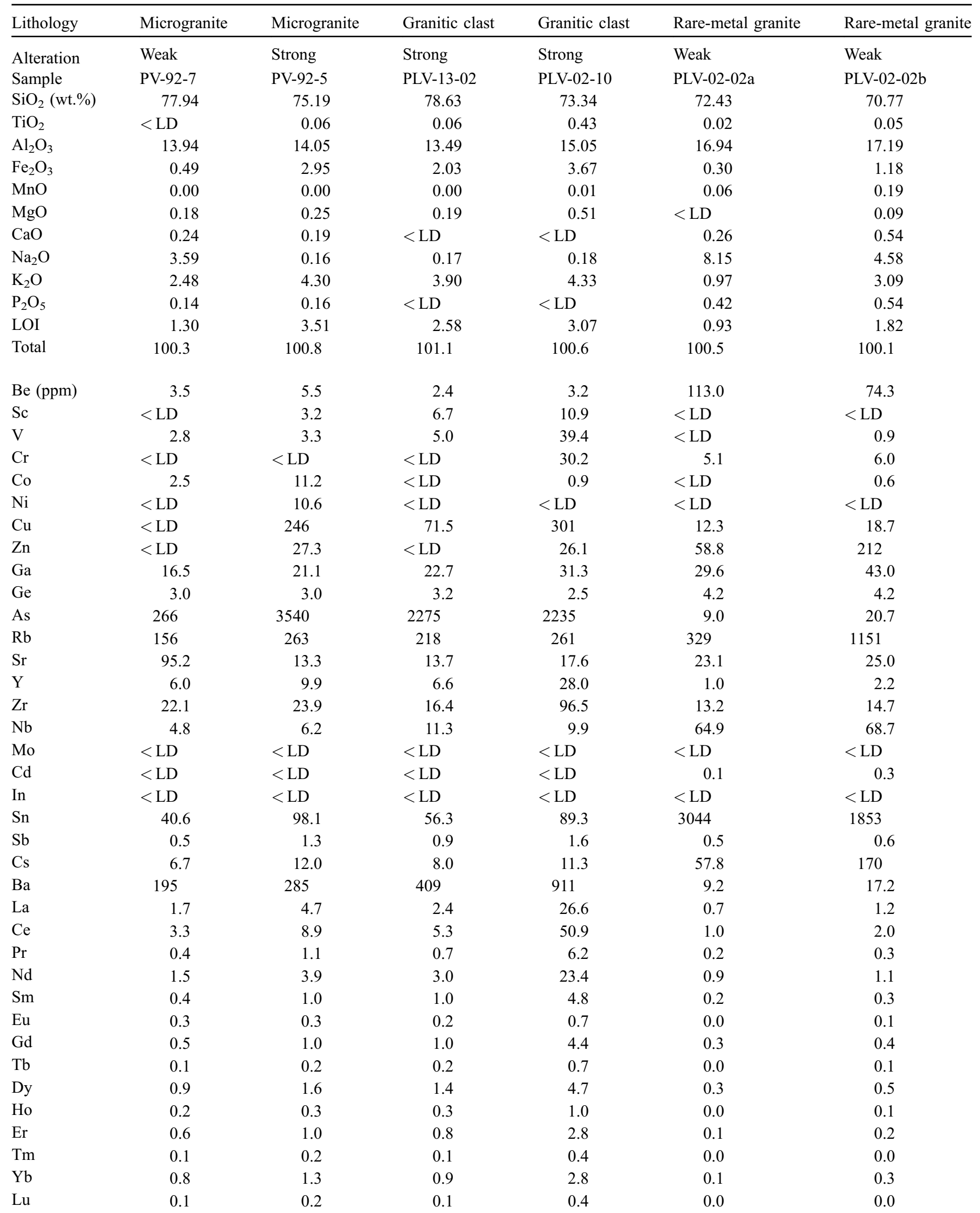


Table 1. (continued).

\begin{tabular}{|c|c|c|c|c|c|c|}
\hline Lithology & Microgranite & Microgranite & Granitic clast & Granitic clast & Rare-metal granite & Rare-metal granite \\
\hline $\mathrm{Ta}$ & 1.9 & 2.0 & 4.5 & 1.6 & 46.0 & 47.5 \\
\hline $\mathrm{Pb}$ & 5.8 & 41.0 & 10.2 & 12.7 & 11.3 & 8.7 \\
\hline $\mathrm{Bi}$ & 2.2 & 34.2 & 26.8 & 27.9 & 1.5 & 5.9 \\
\hline REE & 11.0 & 25.6 & 17.4 & 130.0 & 4.0 & 6.5 \\
\hline $\mathrm{Eu} / \mathrm{Eu}^{*}$ & 1.66 & 0.87 & 0.68 & 0.44 & 0.55 & 0.64 \\
\hline $\mathrm{Ce} / \mathrm{Ce}^{*}$ & 0.94 & 0.96 & 0.95 & 0.96 & 0.62 & 0.81 \\
\hline $\mathrm{Nb} / \mathrm{Ta}$ & 2.54 & 3.15 & 2.50 & 6.16 & 1.41 & 1.45 \\
\hline $\mathrm{Zr} / \mathrm{Hf}$ & 24.59 & 25.80 & 19.12 & 34.01 & 13.23 & 12.67 \\
\hline
\end{tabular}

$<$ LD: below limit of detection.

\section{Crystal chemistry of Nb-Ta-W-Ti-Sn oxides}

\subsection{Rutile}

Chemical compositions of rutile were analyzed by EMPA and LA-ICP-MS and results are reported in Supplementary Tables 2 and 3, respectively. The first type of rutile (Rt-1) corresponds to subeuhedral $\mathrm{Fe}-\mathrm{W}$-rich rutile disseminated in the tourmalinite and in quartz veins. It ranges from 250 to $1000 \mu \mathrm{m}$ in size and shows sector zoning on BSE images (Fig. 7A). Rt-1 is characterized by core having a homogeneous composition (96.5-99.6 wt.\% $\mathrm{TiO}_{2}$ ) and sectors having high contents of $\mathrm{Fe}$ (up to $1.6 \mathrm{wt} . \% \mathrm{FeO}$ ), $\mathrm{Sn}$ (up to $0.5 \mathrm{wt} . \% \mathrm{SnO}_{2}$ ), and $\mathrm{W}$ (up to $5.0 \mathrm{wt} . \% \mathrm{WO}_{3}$ ). The trace element composition shows low contents of Ta (41-250 ppm), Sc (5-29 ppm), Zn (12-63 ppm), Zr (24-170 ppm), and moderate contents of $\mathrm{Nb}$ (576-2463 ppm), $\mathrm{Cu}$ (3-369 ppm), and $\mathrm{Cr}$ (up to $1 \mathrm{wt} \%$ ). The second type of rutile (Rt-2) corresponds to $\mathrm{Nb}$-Ta-rich rutile disseminated in wolframite-bearing quartz veins as grains of 50-250 $\mu \mathrm{m}$ in size (Fig. 7E). Rt-2 shows similar compositions to Rt-1 but differs by rims having high contents of $\mathrm{Nb}$ (up to 12 wt. $\% \mathrm{Nb}_{2} \mathrm{O}_{5}$ ), Ta (up to 5.1 wt. $\% \mathrm{Ta}_{2} \mathrm{O}_{5}$ ), and $\mathrm{Fe}$ (up to 4.8 wt. $\%$ FeO). The third type of rutile (Rt-3) consists of subeuhedral $(500 \mu \mathrm{m}$ in size $) \mathrm{Fe}-\mathrm{Nb}$-rich rutile disseminated within ferberite-1 (Fig. 7F). The chemical composition of Rt-3 is characterized by high contents of $\mathrm{Nb}$ (up to $14.1 \mathrm{wt} \%$ $\mathrm{Nb}_{2} \mathrm{O}_{5}$ ), Ta (up to 1.3 wt. $\% \mathrm{Ta}_{2} \mathrm{O}_{5}$ ), and $\mathrm{Fe}$ (up to 4.5 wt. $\%$ $\mathrm{FeO}$ ), with minor amounts of $\mathrm{W}$ (up to $0.9 \mathrm{wt} . \% \mathrm{WO}_{3}$ ) and $\mathrm{Sn}$ $\left(0.6\right.$ wt. \% $\left.\mathrm{SnO}_{2}\right)$. The last type of rutile (Rt-4) is only found in arsenopyrite as euhedral grains (ca. $250 \mu \mathrm{m}$ ) of $\mathrm{Cr}-\mathrm{Nb}-\mathrm{W}-$ rich rutile showing growth zoning (Fig. $7 \mathrm{~J}$ ). It has uncommon elevated major contents of $\mathrm{Nb}$ (up to $14.2 \mathrm{wt} . \% \mathrm{Nb}_{2} \mathrm{O}_{5}$ ), Ta (up to 2.3 wt. $\% \mathrm{Ta}_{2} \mathrm{O}_{5}$ ), $\mathrm{W}$ (up to $12.1 \mathrm{wt} \% \% \mathrm{WO}_{3}$ ), and $\mathrm{Cr}$ (up to 9.3 wt. $\% \mathrm{Cr}_{2} \mathrm{O}_{3}$ ), as well as trace element enrichment of V (314-1305 ppm), Sc (64-244 ppm), Zn (10-151 ppm), Zr (100-234 ppm), and Sn (1940-2911 ppm). The different types of rutile plot along distinct chemical trends in the ternary diagram $(\mathrm{Nb}+\mathrm{Ta})-(\mathrm{Sn}+\mathrm{Ti}+\mathrm{W})-(\mathrm{Fe}+\mathrm{Mn})$, reflecting variable contribution of the substitution mechanisms $\mathrm{Ti}^{4+}{ }_{-2}(\mathrm{Fe}, \mathrm{Mn})^{2+}{ }_{+1} \mathrm{~W}^{6+}{ }_{+1}, \mathrm{Ti}^{4+}{ }_{-3}(\mathrm{Fe}, \mathrm{Mn})^{2+}{ }_{+1}(\mathrm{Nb}$, $\mathrm{Ta})^{5+}{ }_{+2}$ and $\mathrm{Ti}^{4+}{ }_{-2}(\mathrm{Fe}, \mathrm{Mn})^{3+}{ }_{+1}(\mathrm{Nb}, \mathrm{Ta})^{5+}{ }_{+1}$ (Fig. 11). Using the Zr-in-rutile thermometer of Watson et al. (2006) based on the coexistence of zircon, rutile and quartz, crystallization temperatures between 472 and $623^{\circ} \mathrm{C}(\operatorname{avg}=$ $546 \pm 32^{\circ} \mathrm{C} ; \mathrm{n}=75$ ) were calculated for all rutile grains (Supplementary Table 3).

\subsection{Cassiterite}

Cassiterite from the RMG and from a wolframite-bearing quartz vein were analyzed by EMPA and the chemical compositions are reported in Supplementary Table 4. Magmatic cassiterite disseminated in the RMG ranges from 100 to $500 \mu \mathrm{m}$ in size and shows a discrete zoning on BSE images (Fig. 12A). Its chemical composition is characterized by high contents of $\mathrm{Nb}$ (up to $2.8 \mathrm{wt} . \% \mathrm{Nb}_{2} \mathrm{O}_{5}$ ) and $\mathrm{Ti}$ (up to $1.6 \mathrm{wt} . \%$ $\mathrm{TiO}_{2}$ ), and low contents of $\mathrm{Fe}$ (up to $0.7 \mathrm{wt} \% \mathrm{FeO}$ ). Hydrothermal cassiterite hosted in a quartz-wolframite-sulfide vein consists of subeuhedral grains of 200-400 $\mu \mathrm{m}$ in size with homogeneous texture (Fig. 12B). Its chemical composition is close to the ideal formula of cassiterite with minor contents of $\mathrm{W}$ (up to $1.6 \mathrm{wt} . \% \mathrm{WO}_{3}$ ), $\mathrm{Fe}$ (up to $1.5 \mathrm{wt} . \% \mathrm{FeO}$ ), and $\mathrm{Nb}$ (up to $0.2 \mathrm{wt} . \% \mathrm{Nb}_{2} \mathrm{O}_{5}$ ). Magmatic and hydrothermal cassiterite plot along distinct geochemical trends in the ternary diagram $(\mathrm{Nb}+\mathrm{Ta})-(\mathrm{Sn}+\mathrm{Ti}+\mathrm{W})-(\mathrm{Fe}+\mathrm{Mn})$, reflecting the two heterovalent substitution mechanisms $\mathrm{Sn}^{4+}{ }_{-3}(\mathrm{Fe}, \mathrm{Mn})^{2+}{ }_{+1}(\mathrm{Nb}$, $\mathrm{Ta})^{5+}{ }_{+2}$ and $\mathrm{Sn}^{4+}{ }_{-2}(\mathrm{Fe}, \mathrm{Mn})^{2+}{ }_{+1} \mathrm{~W}^{6+}{ }_{+1}$ (Fig. 12C).

\subsection{Wolframoixiolite}

The W-rich variety of ixiolite (named wolframoixiolite) consists of subeuhedral grains of 200 to $500 \mu \mathrm{m}$ in size that is found in quartz-filled veinlets cutting wolframite and as disseminations in scheelite (Figs. $7 \mathrm{H}$ and 7I). At the grain scale, wolframoixiolite shows a complex zoning composed of successive core, rim, and overgrowth. Chemical compositions 


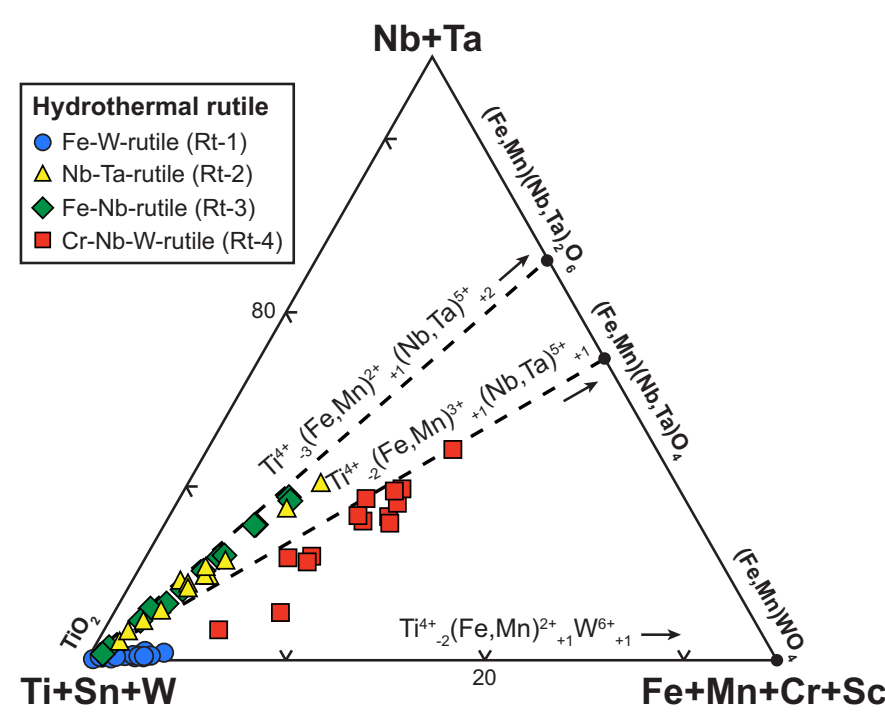

Fig. 11. Chemical compositions of hydrothermal rutile from Puy-lesVignes plotted in the ternary diagram $(\mathrm{Nb}+\mathrm{Ta})-(\mathrm{Ti}+\mathrm{Sn}+\mathrm{W})$ $(\mathrm{Fe}+\mathrm{Mn}+\mathrm{Cr}+\mathrm{Sc})$.
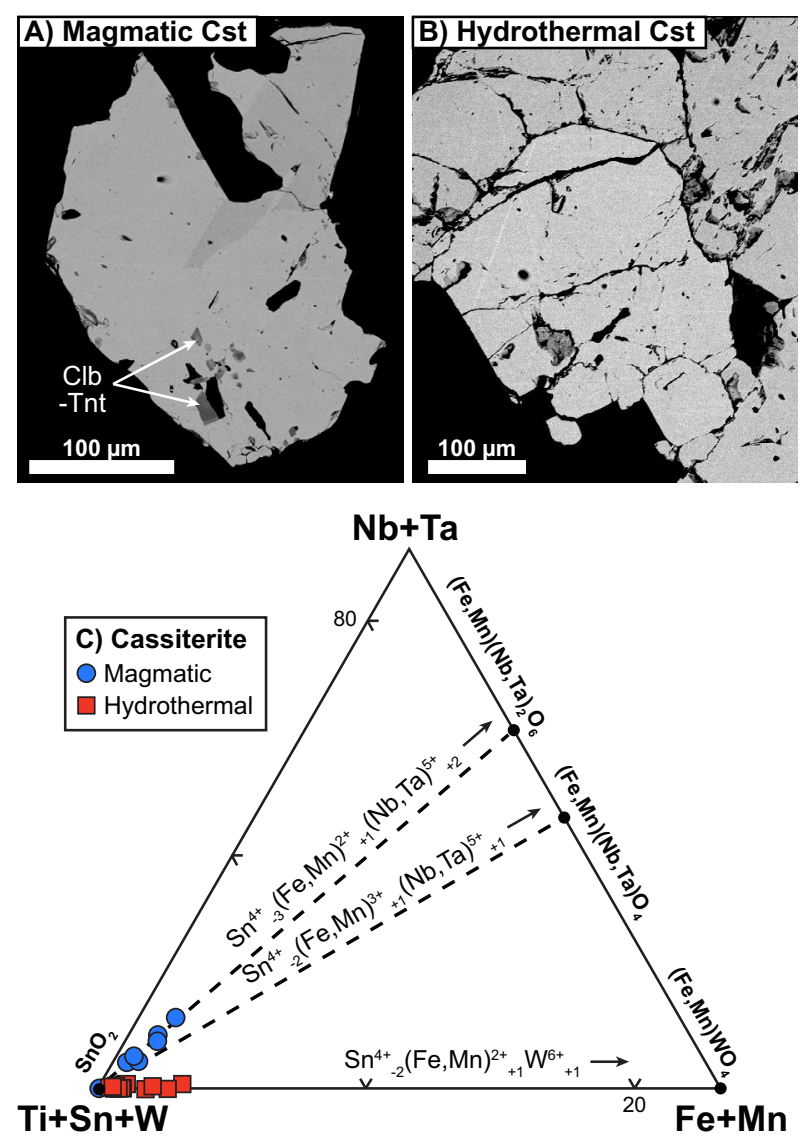

Fig. 12. Backscattered electron images and chemical compositions of magmatic and hydrothermal cassiterite from Puy-les-Vignes plotted in the ternary diagram $(\mathrm{Nb}+\mathrm{Ta})-(\mathrm{Ti}+\mathrm{Sn}+\mathrm{W})-(\mathrm{Fe}+\mathrm{Mn})$. Magmatic cassiterite differs texturally from hydrothermal cassiterite by a discrete zoning and microinclusions of columbite-tantalite minerals (Clb-Tnt).

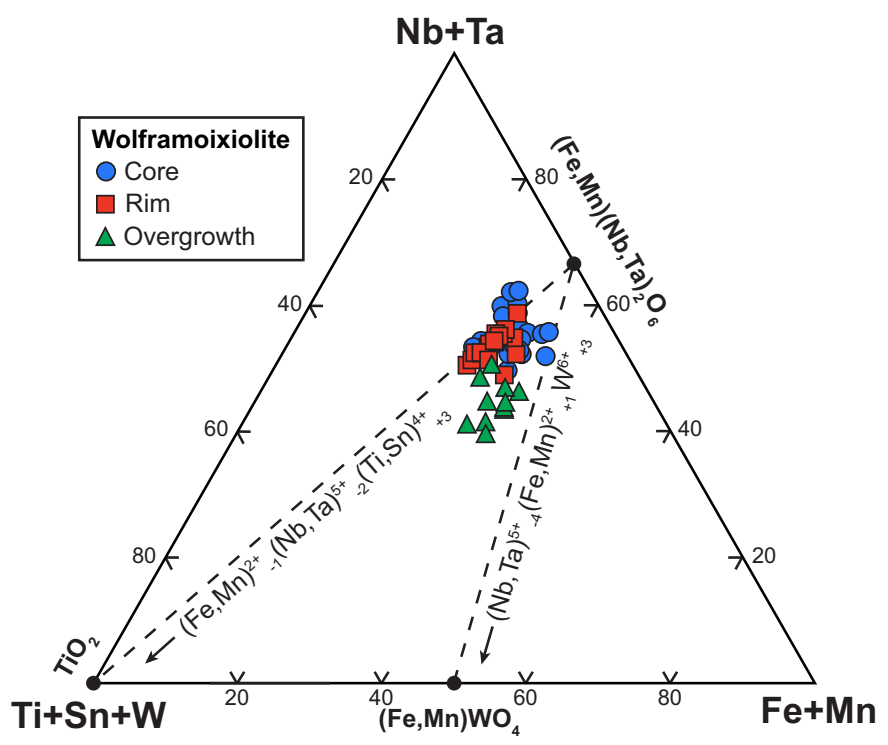

Fig. 13. Chemical compositions of wolframoixiolite from Puy-lesVignes plotted in the ternary diagram $(\mathrm{Nb}+\mathrm{Ta})-(\mathrm{Ti}+\mathrm{Sn}+\mathrm{W})$ $(\mathrm{Fe}+\mathrm{Mn})$.
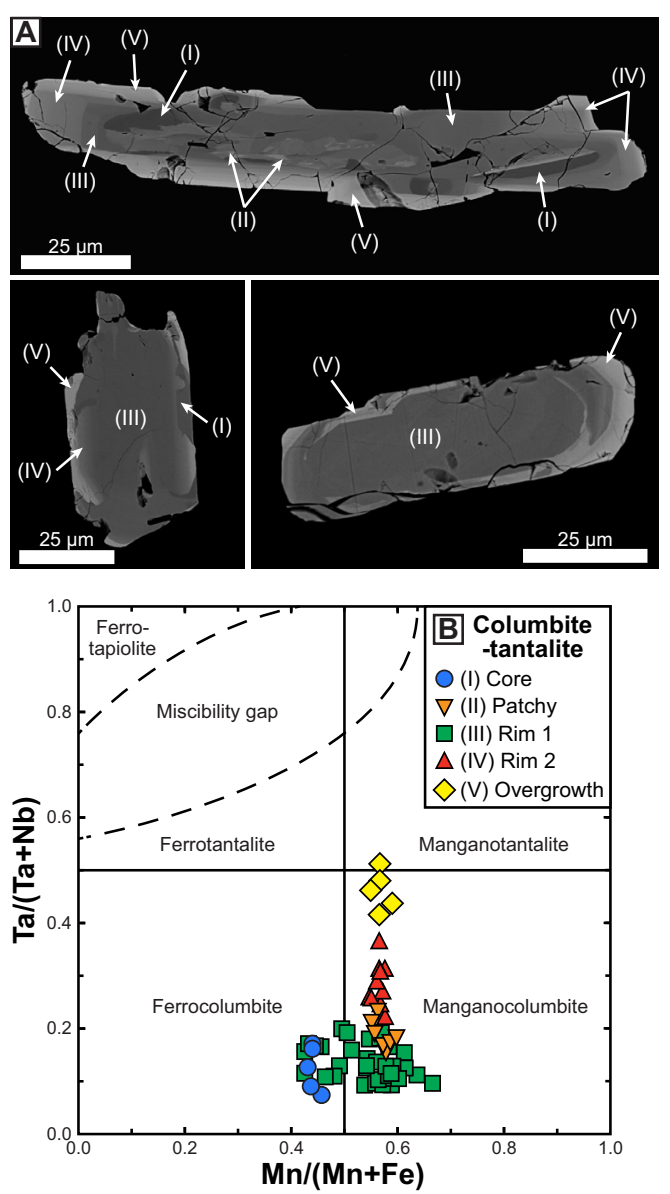

Fig. 14. (A) Backscattered electron images of columbite-tantalite disseminated in the Puy-les-Vignes RMG. (B) Chemical compositions of columbite-tantalite plotted in the $\mathrm{Ta} /(\mathrm{Ta}+\mathrm{Nb})$ vs. $\mathrm{Mn} /$ $(\mathrm{Fe}+\mathrm{Mn})$ diagram. 
of wolframoixiolite were determined by EMPA and are reported in Supplementary Table 5. The core and rim have overlapping compositions characterized by high contents of $\mathrm{Nb}\left(52.7-66.6\right.$ wt.\% $\left.\mathrm{Nb}_{2} \mathrm{O}_{5}\right)$, $\mathrm{Fe}(13.6-17.1$ wt. $\% \mathrm{FeO})$ and $\mathrm{Mn}(2.5-4.6 \mathrm{wt} . \% \mathrm{MnO})$, and low contents of $\mathrm{W}$ (7.023.1wt.\% $\mathrm{WO}_{3}$ ) and $\mathrm{Ti}\left(2.4-9.8\right.$ wt. $\% \mathrm{TiO}_{2}$ ). In contrast, the overgrowth is distinguished by lower contents of $\mathrm{Nb}(40.4$ 49.7 wt. $\% \mathrm{Nb}_{2} \mathrm{O}_{5}$ ) and higher contents of $\mathrm{W}(21.9-33.4 \mathrm{wt} . \%$ $\left.\mathrm{WO}_{3}\right)$. When plotted in the ternary diagram $(\mathrm{Nb}+\mathrm{Ta})-$ $(\mathrm{Sn}+\mathrm{Ti}+\mathrm{W})-(\mathrm{Fe}+\mathrm{Mn})$, the chemical composition of wolframoixiolite reflects the coupled substitution mechanisms $(\mathrm{Nb}$, $\mathrm{Ta})^{5+}{ }_{-4}(\mathrm{Fe}, \mathrm{Mn})^{2+}{ }_{+1} \mathrm{~W}^{6+}{ }_{+3}$ and $(\mathrm{Fe}, \mathrm{Mn})^{2+}{ }_{-1}(\mathrm{Nb}, \mathrm{Ta})^{5+}{ }_{-2}(\mathrm{Ti}$, $\mathrm{Sn})^{4+}{ }_{+3}$ (Fig. 13).

\subsection{Columbite-tantalite}

Columbite-tantalite occurs as $100-200 \mu \mathrm{m}$-size subeuhedral grains disseminated in the groundmass of the RMG or as microinclusions (5 to $20 \mu \mathrm{m}$ ) hosted in magmatic cassiterite. At the microscopic scale, columbite-tantalite shows a zoning composed of five distinct zones (Fig. 14A): (i) ovoid dark core of $15-20 \mu \mathrm{m}$ in size corresponding to the initial nucleus; (ii) an irregular patchy zone close to the core; (iii) a rim-1 of medium grey color surrounding the core and showing growth banding; (iv) a rim-2 having a light grey contrast in continuity to rim-1; and (v) an overgrowth, rarely exceeding $10 \mu \mathrm{m}$ in thickness, which shows dissolution texture at the interface with the rim and represents a late stage of crystallization. Chemical compositions of columbite-tantalite were determined by EMPA and results are shown in Supplementary Table 6. The core has higher contents of $\mathrm{Fe}$ (up to $11.6 \mathrm{wt} . \% \mathrm{FeO}$ ) and $\mathrm{Nb}$ (up to $65.6 \mathrm{wt} . \%$ $\mathrm{Nb}_{2} \mathrm{O}_{5}$ ) and lower contents of $\mathrm{Mn}$ (up to $9.2 \mathrm{wt} . \% \mathrm{MnO}$ ) and $\mathrm{Ta}$ (up to $19.6 \mathrm{wt} . \% \mathrm{Ta}_{2} \mathrm{O}_{5}$ ) relative to the rims. The overgrowth shows contrasting compositions with high contents of $\mathrm{Ta}$ (up to $48.0 \mathrm{wt} . \% \mathrm{Ta}_{2} \mathrm{O}_{5}$ ) and $\mathrm{Mn}$ (up to $10.2 \mathrm{wt} . \% \mathrm{MnO}$ ) and low contents of $\mathrm{Fe}$ (up to $7.7 \mathrm{wt} . \% \mathrm{FeO}$ ) and $\mathrm{Nb}$ (up to $\left.36.7 \mathrm{wt} . \% \mathrm{Nb}_{2} \mathrm{O}_{5}\right)$. In the $\mathrm{Ta} /(\mathrm{Ta}+\mathrm{Nb})$ vs. $\mathrm{Mn} /(\mathrm{Fe}+\mathrm{Mn})$ diagram (Fig. 14B), the composition of columbite-tantalite shows a trend of increasing the $\mathrm{Ta} /(\mathrm{Ta}+\mathrm{Nb})$ ratio (from 0.07 to 0.51 ) at relatively constant $\mathrm{Mn} /(\mathrm{Mn}+\mathrm{Fe}$ ) ratio $(0.42-0.67)$ from core to overgrowth. These chemical variations are related to the coupled heterovalent substitutions $(\mathrm{Nb}, \mathrm{Ta})^{5+}{ }_{-2}(\mathrm{Ti}, \mathrm{Sn})^{4+}{ }_{+1} \mathrm{~W}^{6+}{ }_{+1}$ and $(\mathrm{Fe}, \mathrm{Mn})^{2+}{ }_{-1}(\mathrm{Nb}$, $\mathrm{Ta})^{5+}{ }_{-2}(\mathrm{Ti}, \mathrm{Sn})^{4+}{ }_{+3}$, and the isovalent substitutions $\mathrm{Nb}^{5+}{ }_{-1} \mathrm{Ta}^{5+}+1$ and $\mathrm{Fe}^{2+}{ }_{-1} \mathrm{Mn}^{2+}{ }_{+1}$.

\section{$7 \mathrm{U} / \mathrm{Pb}$ and ${ }^{40} \mathrm{Ar} /{ }^{39} \mathrm{Ar}$ geochronology}

\section{1 $\mathrm{U} / \mathrm{Pb}$ dating of rutile}

Two samples of quartz-wolframite-arsenopyrite veins (samples PLV-7574a and PLV-02-28b) containing rutile were selected for in situ U/Pb LA-ICP-MS dating. Results are shown in Figure 15 and data are reported in Table 2. The analyzed rutile grains have low $\mathrm{U}$ contents ranging from 0.9 to $5.7 \mathrm{ppm}$ and very low $\mathrm{Pb}$ contents ranging from 0.07 to $2.02 \mathrm{ppm}$. The Th contents are below $1 \mathrm{ppm}$. The isotopic compositions of rutile are variable with ${ }^{238} \mathrm{U} /{ }^{206} \mathrm{~Pb}$ ratios ranging from 7.03 to 18.63 and ${ }^{207} \mathrm{~Pb} /{ }^{206} \mathrm{~Pb}$ ratios ranging from
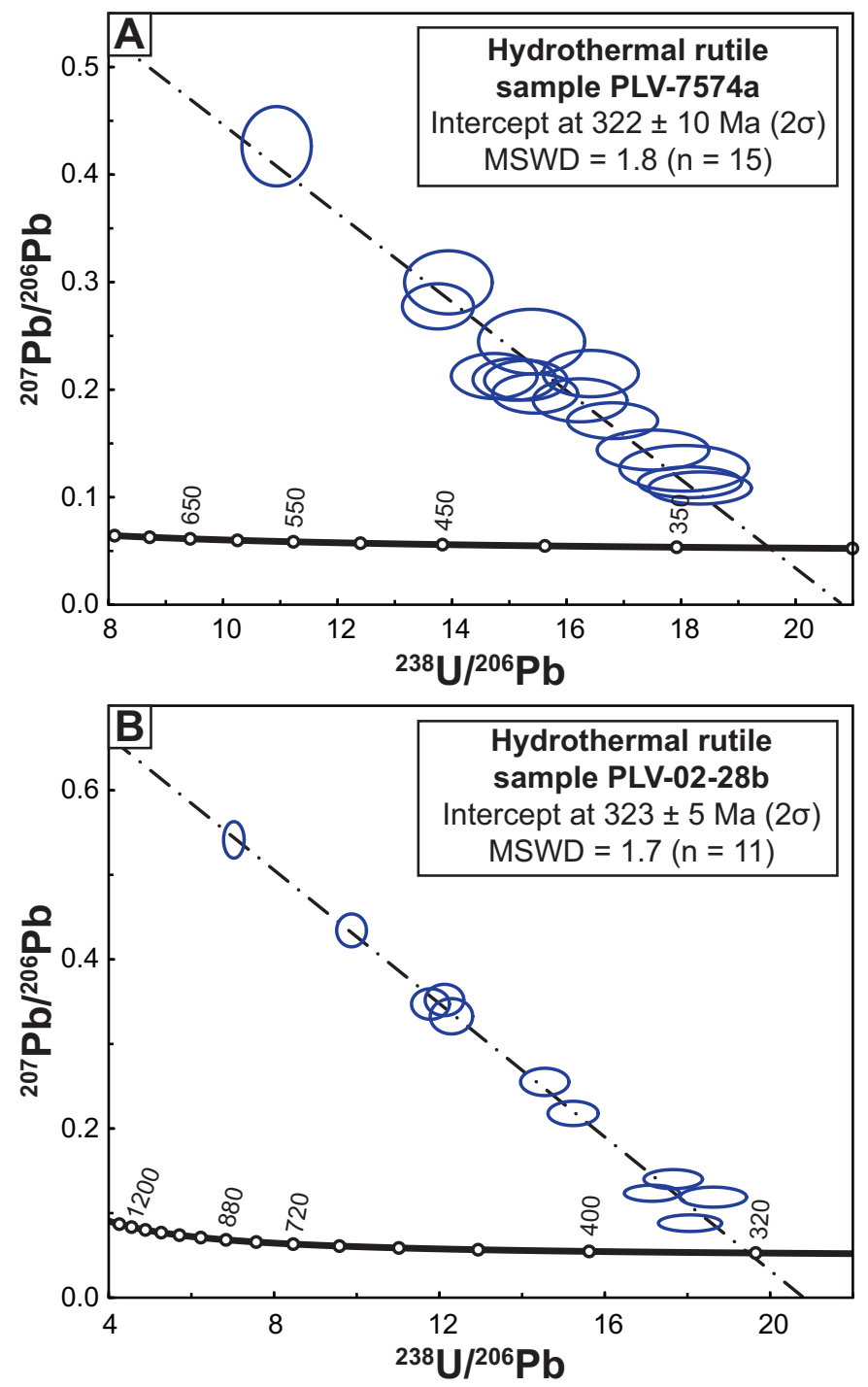

Fig. 15. Tera-Wasserburg diagrams for two samples of hydrothermal rutile hosted in quartz-wolframite-arsenopyrite veins from the Puyles-Vignes deposit. Weighted mean ages are calculated from linear regression of the discordia line crossing the concordia curve at its lower-age intercept. Error ellipses are quoted at $2 \sigma$ level of uncertainty. $\mathrm{U} / \mathrm{Pb}$ isotopic data are reported in Table 2.

0.09 to 0.54 . All data are discordant in the Tera-Wasserburg diagram, which is a common feature of hydrothermal rutile (Boutin et al., 2016). Sample PLV-7574a contains hydrothermal rutile (Rt-2) disseminated in a wolframite-bearing quartz vein and is thought to be formed prior or concomitantly to wolframite deposition. The $\mathrm{U}$ and $\mathrm{Pb}$ contents of rutile range from 0.90 to $1.8 \mathrm{ppm}$ and 0.07 to $0.22 \mathrm{ppm}$, respectively. The sample has relatively high radiogenic composition with ${ }^{238} \mathrm{U} /{ }^{206} \mathrm{~Pb}$ values ranging from 10.93 to 18.33 and ${ }^{207} \mathrm{~Pb} /{ }^{206} \mathrm{~Pb}$ values from 0.11 to 0.43 . The data $(\mathrm{n}=15)$ define a discordia line with a lower intercept date of $322 \pm 10 \mathrm{Ma}(2 \sigma$, $\mathrm{MSWD}=1.8$; Fig. 15A). Sample PLV-02-28b contains hydrothermal rutile (Rt-4) hosted in arsenopyrite from a quartz-wolframite vein. Rutile grains from sample PLV02-28b have low $\mathrm{U}$ and $\mathrm{Pb}$ contents ranging from 3.5 to 
Table 2. U-Pb isotopic data for hydrothermal rutile from the Puy-les-Vignes deposit.

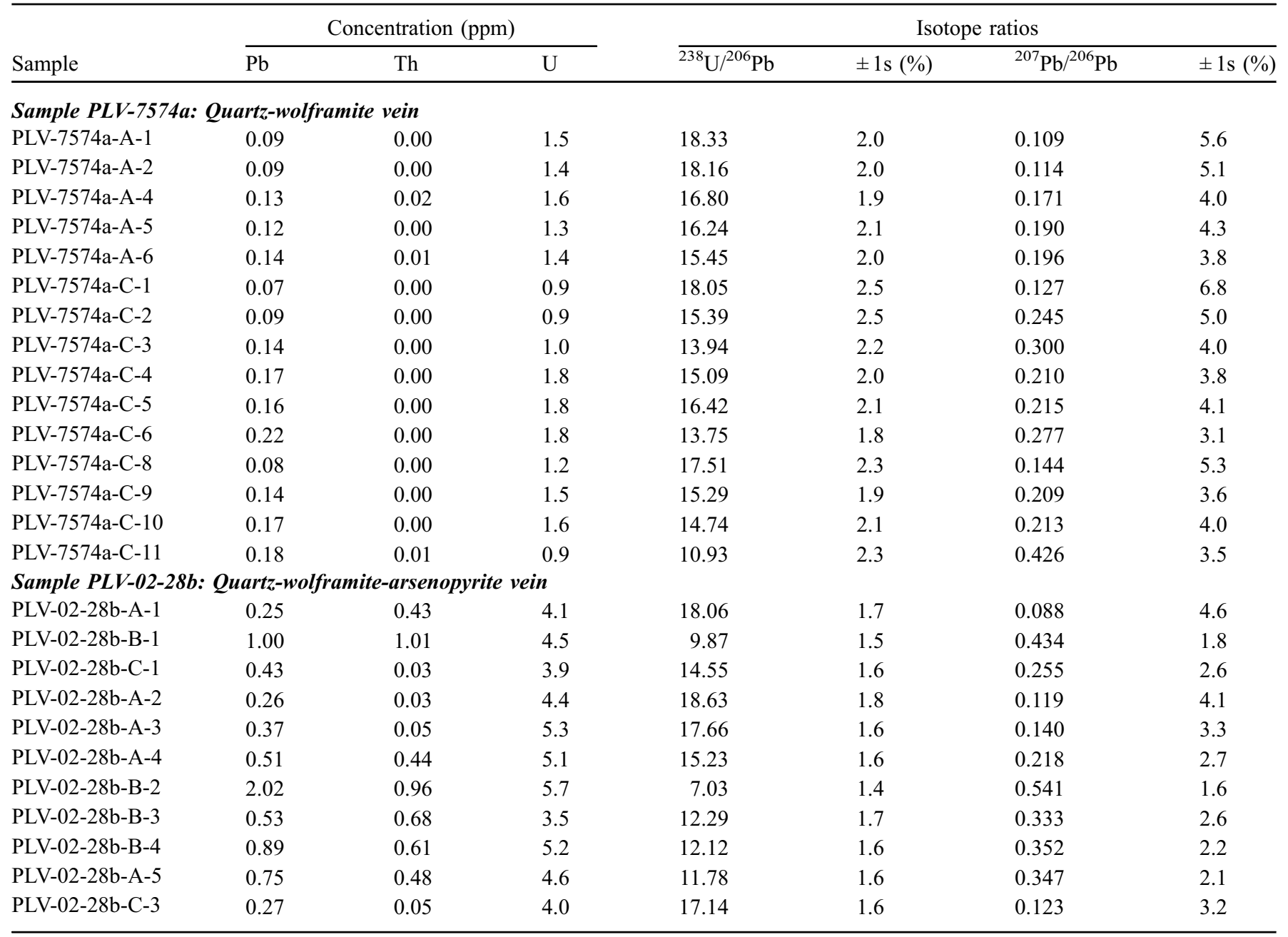

$5.7 \mathrm{ppm}$ and 0.25 to $2.0 \mathrm{ppm}$, respectively. They have variable ratios of ${ }^{238} \mathrm{U} /{ }^{206} \mathrm{~Pb}(7.03-18.63)$ and ${ }^{207} \mathrm{~Pb} /{ }^{206} \mathrm{~Pb}(0.09-0.54)$. Linear regression of the data $(n=11)$ in the Tera-Wasserburg diagram yields a lower intercept date of $323 \pm 5 \mathrm{Ma}(2 \sigma$, $\mathrm{MSWD}=1.7$; Fig. 15B).

\section{2 ${ }^{40} \mathrm{Ar} /{ }^{39} \mathrm{Ar}$ dating of micas and adularia}

Five samples containing micas and one sample with adularia were selected for in situ ${ }^{40} \mathrm{Ar} /{ }^{39} \mathrm{Ar}$ dating. Results of the ${ }^{40} \mathrm{Ar} /{ }^{39} \mathrm{Ar}$ analyses are shown in Figure 16 and the dataset is reported in Table 3. Magmatic muscovite from a microgranite (sample PV-92-7) gives ${ }^{40} \mathrm{Ar} /{ }^{39} \mathrm{Ar}$ apparent ages ranging from ca. 306 to ca. $336 \mathrm{Ma}(\mathrm{n}=12)$ and a weighted mean date of $323 \pm 4 \mathrm{Ma}(2 \sigma, \mathrm{MSWD}=1.7$; Fig. 16A). The ${ }^{40} \mathrm{Ar} /{ }^{39} \mathrm{Ar}$ apparent ages for magmatic biotite from a lamprophyre (sample PV-92-17) overlap between ca.325 and ca. $347 \mathrm{Ma}(\mathrm{n}=3)$ and yield a weighted mean date of $331 \pm 14 \mathrm{Ma}(2 \sigma, \mathrm{MSWD}=0.8$; Fig. 16B). Magmatic muscovite from the RMG (sample PLV-02-02b) yields ${ }^{40} \mathrm{Ar} /{ }^{39} \mathrm{Ar}$ apparent ages comprised between ca. 293 and ca. $323 \mathrm{Ma}$ $(\mathrm{n}=7)$ and a weighted mean date of $311 \pm 5 \mathrm{Ma}(2 \sigma$, $\mathrm{MSWD}=2.6$; Fig. 16C). Hydrothermal muscovite from a greisenized gneiss clast (sample PLV-02-01a; stage I) yields
${ }^{40} \mathrm{Ar} /{ }^{39} \mathrm{Ar}$ apparent ages ranging from ca. 308 to ca. $326 \mathrm{Ma}$ $(n=6)$ and a weighted mean date of $318 \pm 5 \mathrm{Ma}(2 \sigma$, MSWD =1.2; Fig. 16D). The ${ }^{40} \mathrm{Ar} /{ }^{39} \mathrm{Ar}$ apparent ages for hydrothermal muscovite from a quartz-wolframite vein (sample PV1; stage II) range between ca. 310 and ca. $338 \mathrm{Ma}$ $(\mathrm{n}=8)$ and yield a weighted mean date of $324 \pm 5 \mathrm{Ma}$ $(2 \sigma, \mathrm{MSWD}=1.7$; Fig. 16E). Adularia from a tourmaline microbreccia (sample PLV-02-13b; stage IV) gives ${ }^{40} \mathrm{Ar} /{ }^{39} \mathrm{Ar}$ apparent ages between ca. 296 and ca. $310 \mathrm{Ma}(\mathrm{n}=6)$ and a weighted mean date of $302 \pm 4 \mathrm{Ma}(2 \sigma, \quad M S W D=1.7$; Fig. 16F).

\section{Fluid inclusions}

\subsection{Petrography and microthermometry of fluid inclusions hosted in quartz}

Fluid inclusions (FIs) have been studied in representative quartz-wolframite vein samples ("filon 2" and "filon T18") from the Puy-les-Vignes deposit. The studied FIs were identified in two distinct generations of quartz. Quartz Q1 forms the main gangue of the vein, similar to the breccia cement, and is interpreted as coeval with wolframite deposition (stage II). Quartz Q1 consists of large crystals having a milky 


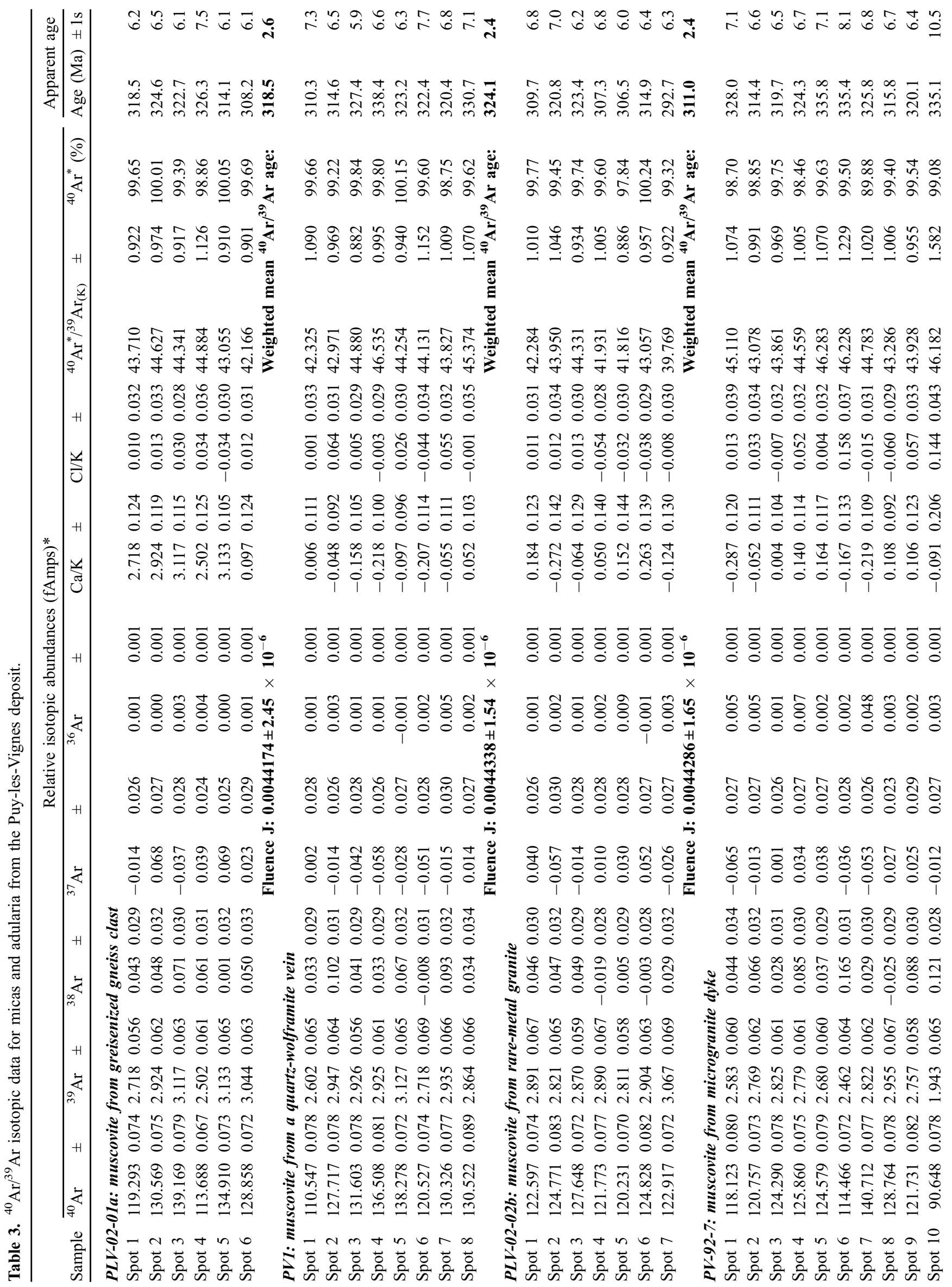




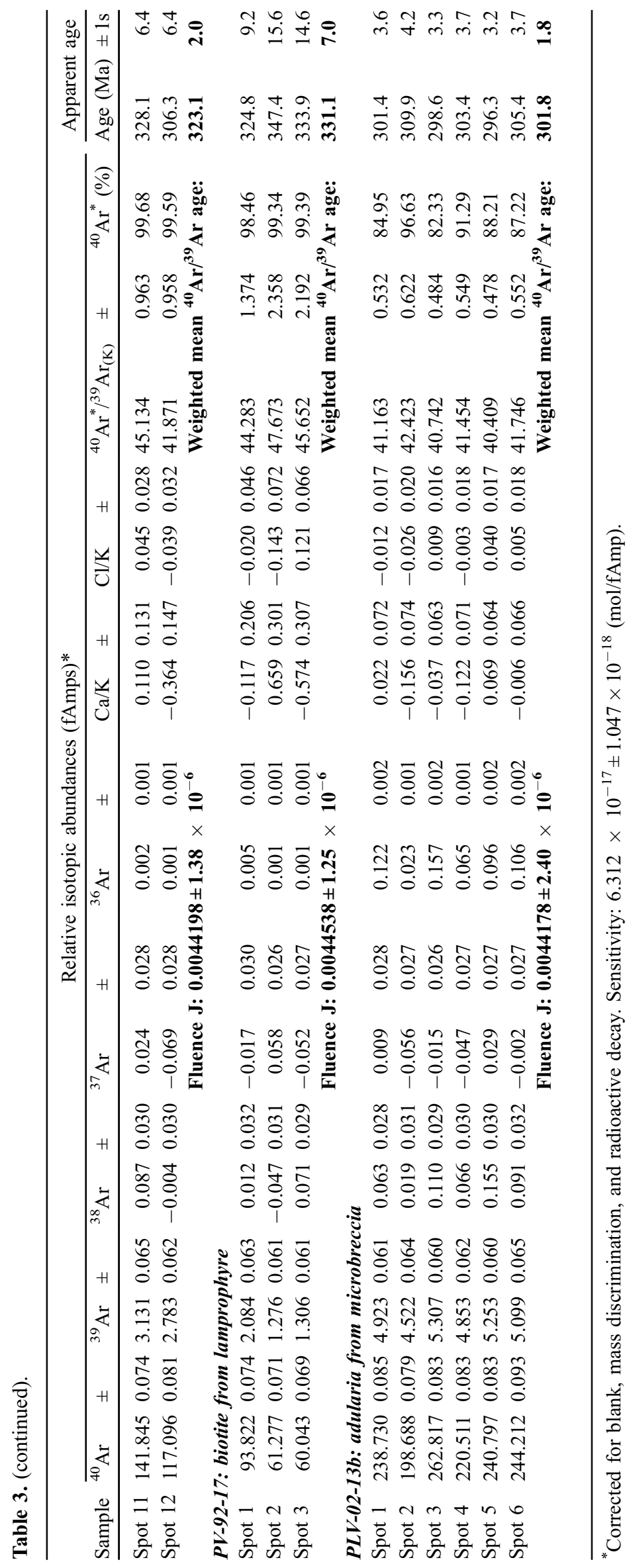


color with a high density of FIs and showing evidence of ductile deformation and dynamic recrystallization. Primary zoning is locally preserved in Q1 but most FIs aligned along growth zones are decrepitated. Quartz Q2 is found in recrystallized zones of Q1 and is coeval with the base metal sulfide assemblage (stage III). In contrast to Q1, quartz Q2 corresponds to fully transparent undeformed quartz crystals containing less FIs. Based on petrography and microthermometry, three main types of quartz-hosted FIs are distinguished in both Q1 and Q2 (Tab. 4):

1 Aqueous-carbonic Lc-w: They are mainly found in Q1 either as isolated or clustered FIs, interpreted as primary, and as pseudo-secondary FI planes (FIP) sealing microcracks. Many Lc-w show reequilibration features (e.g., stretching, leaking, neonate halo) or are decrepitated (Figs. 17A-17C). The Lc-w contain three phases at room temperature or upon the beginning of cooling, i.e., a carbonic liquid phase $\left(\mathrm{L}_{\mathrm{car}}\right)$, a carbonic vapor phase $\left(\mathrm{V}_{\mathrm{car}}\right)$, and an aqueous liquid phase $\left(\mathrm{L}_{\mathrm{aq}}\right)$. They occasionally contain small $(<2 \mu \mathrm{m})$ dark solids that could not be analyzed by Raman spectroscopy but may be graphite. The Lc-w have variable morphology, ranging from very irregular to regular (Figs. 17F-17J). Their size varies between 5 and $70 \mu \mathrm{m}(\operatorname{avg}=20 \mu \mathrm{m})$, with the regular FIs being generally smaller $(5-20 \mu \mathrm{m})$ than the irregular ones $(30-70 \mu \mathrm{m})$. The ratio between the volatile phase and the FI volume at room temperature $(\mathrm{Rv})$ is highly variable $(0.10-0.70$, avg $=0.40)$. The Lc-w have low $\mathrm{CO}_{2}$ melting temperatures $\left(\mathrm{Tm} \mathrm{CO} \mathrm{CO}_{2}=-64.3\right.$ to $\left.-56.6^{\circ} \mathrm{C}\right)$ and variable clathrate melting temperatures $\left(\mathrm{Tm}\right.$ clat $=3.9$ to $\left.13.1^{\circ} \mathrm{C}\right)$, indicating the presence of other gases in the volatile phase in addition to $\mathrm{CO}_{2}$ (Figs. 19A and 19B). Homogenization of the volatile phase occurs dominantly to the vapor phase ( $\mathrm{Th} \mathrm{CO}_{2}=-9.7$ to $23.3^{\circ} \mathrm{C}$ ) but homogenization in the liquid or critical phase has been observed. The eutectic temperatures $\left(\mathrm{Te}=-24.5\right.$ to $\left.-21.1{ }^{\circ} \mathrm{C}\right)$ indicate an $\mathrm{H}_{2} \mathrm{O}-\mathrm{NaCl}-(\mathrm{KCl})$ composition. Total homogenization of the Lc-w occurs dominantly to the liquid phase over a large range of temperatures $\left(\mathrm{Th}=249\right.$ to $\left.455^{\circ} \mathrm{C}\right)$. Decrepitation before total homogenization of $\mathrm{Lc}-\mathrm{w}$ is frequent upon heating $\left(\mathrm{Td}=250\right.$ to $\left.400{ }^{\circ} \mathrm{C}\right)$. Salinities calculated based on the $\mathrm{Tm}$ clat and $\mathrm{Th}_{2}$ range from 2.2 to $8.1 \mathrm{wt} . \% \mathrm{NaCl}$ eq (avg $=5.3 \mathrm{wt} . \% \mathrm{NaCl}$ eq) and bulk densities are comprised between 0.36 and $0.92 \mathrm{~g} \mathrm{~cm}^{-3} \quad\left(\mathrm{avg}=0.67 \mathrm{~g} \mathrm{~cm}^{-3}\right.$; Figs. 19A-19C).

2 Aqueous-carbonic $L w$-c: They correspond to primary and pseudo-secondary FIP forming trails along grain boundaries and growth zones in Q1 and Q2 (Figs. 17C-17E). Crosscutting relations suggest that the Lw-c postdate the Lc-w. The Lw-c consist of two-phase FIs at room temperature with a dominant aqueous liquid phase $\left(\mathrm{L}_{\mathrm{aq}}\right)$ over the vapor phase $(\mathrm{V})$ with variable $\mathrm{Rv}$ ratios $(0.10-0.50$, $\mathrm{avg}=0.20$ ). Some Lw-c hosted in Q2 contain chalcopyrite microinclusions resulting likely from heterogeneous trapping. The Lw-c have variable size $(10-50 \mu \mathrm{m}$, avg $=20 \mu \mathrm{m})$ and morphology, ranging from very irregular to regular, the largest ones commonly showing irregular shapes (Figs. 17K-17N). Although the carbonic liquid phase is absent, many Lw-c exhibit melting of a carbonic phase upon heating following freezing. The measured $\mathrm{Tm} \mathrm{CO}_{2}$ varies from -103.3 to $-57.4{ }^{\circ} \mathrm{C}$, indicating the presence of other components than $\mathrm{CO}_{2}$ in the volatile phase, which is confirmed by the range of $\mathrm{Tm}$ clat $\left(2.9-15.2{ }^{\circ} \mathrm{C}\right)$. The Lw-c hosted in Q1 and Q2 differ by their $\mathrm{Tm} \mathrm{CO}_{2}$ and Tm clat values (Figs. 19A and 19B). The eutectic temperatures $\left(\mathrm{Te}=-38\right.$ to $\left.-21.1^{\circ} \mathrm{C}\right)$ are consistent with a $\mathrm{H}_{2} \mathrm{O}-\mathrm{NaCl}-(\mathrm{KCl}) \pm\left(\mathrm{MgCl}_{2}\right)$ composition. Total homogenization occurs dominantly to the liquid phase between 246 and $412^{\circ} \mathrm{C}$. Decrepitation of irregular Lw-c before total homogenization is frequent upon heating at temperatures similar to the Lc-w. Calculated salinities are comprised between 0.7 and $5.8 \mathrm{wt} . \% \mathrm{NaCl}$ eq (avg $=$ $2.6 \mathrm{wt} . \% \mathrm{NaCl}$ eq) and bulk densities range from 0.47 to $0.92 \mathrm{~g} \mathrm{~cm}^{-3}$ (avg $=0.67 \mathrm{~g} \mathrm{~cm}^{-3}$; Fig. 19C).

3 Aqueous Lw: They occur as secondary FIP cutting the Lc-w and Lw-c FIs (Fig. 18D). The Lw are two-phase at room temperature with a dominant aqueous liquid phase over the vapor phase $(\mathrm{Rv}=0.05-0.35$, avg $=0.10)$. They are generally small (typically $<10 \mu \mathrm{m}$ ) and have regular shapes (Figs. 17O and 17P). The eutectic temperatures $\left(\mathrm{Te}=-23\right.$ to $\left.-21.6^{\circ} \mathrm{C}\right)$ indicate $\mathrm{a}_{2} \mathrm{O}-\mathrm{NaCl}$ composition of the aqueous phase. Ice melting temperatures show a limited range of values $\left(\mathrm{Tm}\right.$ ice $=-5.5$ to $\left.-0.2^{\circ} \mathrm{C}\right)$. No clathrate melting was observed. Total homogenization always occurs to the liquid phase between 124 and $391{ }^{\circ} \mathrm{C}$. Salinities calculated based on the $\mathrm{Tm}$ ice are comprised between 0.3 and $8.6 \mathrm{wt} . \% \mathrm{NaCl}$ eq $(\mathrm{avg}=4.9 \mathrm{wt} . \% \mathrm{NaCl}$ eq) and bulk densities range from 0.63 to $0.99 \mathrm{~g} \mathrm{~cm}^{-3}$ (avg $=0.85 \mathrm{~g} \mathrm{~cm}^{-3}$; Fig. 19D).

\subsection{Petrography and microthermometry of fluid inclusions hosted in wolframite}

Wolframite from a quartz vein sample ("filon 2") has been studied by NIR microscopy for complementing the study of FIs hosted in the coexisting quartz. Under NIR transmitted light, wolframite shows evidence of deformation and is crosscut by numerous cracks that opacify the crystal (Figs. 18A and 18B). Two main types of FIs were observed in transparent zones within wolframite: aqueous-carbonic (Lw-c) and aqueous (Lw) FIs. Three-phase volatile-rich Lc-w FIs have not been found in wolframite. The Lw correspond to secondary FIP of small $(5-15 \mu \mathrm{m})$ two-phase $\left(\mathrm{L}_{\mathrm{aq}}+\mathrm{V}\right)$ FIs. They have a negative crystal shape making most of them completely opaque under NIR microscopy (Fig. 18C). Only the Lw-c could be analyzed by microthermometry (Tab. 4). They correspond to primary FIs aligned along the c-axis of wolframite (Fig. 18D) and trails of pseudo-secondary FIs (Fig. 18E). The Lw-c have regular to slightly irregular shapes and their size range from 20 to $50 \mu \mathrm{m}$ ( $\mathrm{avg}=30 \mu \mathrm{m})$. They are two-phase at room temperature with equal proportions of the vapor phase and the aqueous liquid phase $(\mathrm{Rv}=0.30-0.60$, avg $=0.45$; Figs. $18 \mathrm{~F}-18 \mathrm{M}$ ). No $\mathrm{CO}_{2}$ melting and eutectic melting temperatures were observed. Ice-melting temperatures are comprised between -5.6 and $-3.0^{\circ} \mathrm{C}$ and clathrate melting temperatures range from 11.0 to $14.5^{\circ} \mathrm{C}$ (Fig. 19B). Total homogenization occurs to the liquid phase between 344 and $365^{\circ} \mathrm{C}$. Salinities calculated based on the Tm ice are comprised between 5.0 and $8.7 \mathrm{wt} . \% \mathrm{NaCl}$ eq $(\mathrm{avg}=6.6 \mathrm{wt} . \% \mathrm{NaCl}$ eq) 
and bulk densities range from 0.66 to $0.73 \mathrm{~g} \mathrm{~cm}^{-3}$ (avg= $0.69 \mathrm{~g} \mathrm{~cm}^{-3}$; Fig. 19C).

\subsection{Raman spectroscopy and bulk compositions of fluid inclusions}

Raman spectroscopy data were acquired for quartz-hosted Lc-w and Lw-c only (Tab. 4, Figs. 19E and 19F). Due to their small size, no Raman spectroscopy analysis of Lw was possible. The Lc-w and $\mathrm{Lw}-\mathrm{c}$ have a mixed volatile content composed of $\mathrm{CO}_{2}, \mathrm{CH}_{4}$ and $\mathrm{N}_{2}$ (Fig. 19E). The volatile phase of Lc-w is dominantly composed of $\mathrm{CO}_{2}(69-98 \mathrm{~mol} \%)$ and $\mathrm{N}_{2}$ $(0-26 \mathrm{~mol} \%)$ with minor amount of $\mathrm{CH}_{4}(0-12 \mathrm{~mol} \%)$ and traces of $\mathrm{H}_{2} \mathrm{~S}$ (up to $0.3 \mathrm{~mol} \%$ ). In contrast, the $\mathrm{Lw}-\mathrm{c}$ contain highly variable contents of $\mathrm{CO}_{2}(0-100 \mathrm{~mol} \%), \mathrm{CH}_{4}(0-$ $86 \mathrm{~mol} \%)$ and $\mathrm{N}_{2}(0-41 \mathrm{~mol} \%)$ with traces of $\mathrm{H}_{2} \mathrm{~S}$ (up to $1.1 \mathrm{~mol} \%)$. The Lc-w and Lw-c hosted in Q1 are characterized by higher $\mathrm{CO}_{2} / \mathrm{CH}_{4}$ ratios relative to the ones hosted in Q2 (Fig. 19E). Compared to the Lw-c, the calculated bulk compositions of Lc-w are lower for $\mathrm{H}_{2} \mathrm{O}(71-88 \mathrm{~mol} \%)$ and $\mathrm{CH}_{4}(0.2-4.9 \mathrm{~mol} \%)$ but higher for $\mathrm{CO}_{2}(9-26 \mathrm{~mol} \%)$. The bulk $\mathrm{NaCl}$ content of FIs increases (from 0.1 to $2.1 \mathrm{~mol} \%$ ) when the volatile content decreases (from 28 to $2.5 \mathrm{~mol} \%$; Fig. 19F). From Q1 to Q2, the $\mathrm{Lc}-\mathrm{w}$ and $\mathrm{Lw}$-c have increasing $\mathrm{CH}_{4}$ content in the volatile phase (from $0-20 \mathrm{~mol} \%$ in Q1 to $20-60 \mathrm{~mol} \%$ in Q2) while the $\mathrm{N}_{2}$ content does not vary significantly. No Raman spectroscopy measurements of FIs in wolframite could be performed due to the strong laser energy absorption by the host mineral. However, the absence of observable $\mathrm{CO}_{2}$ melting in wolframite-hosted Lw-c indicates a low volatile content while the values of Tm clat $>10^{\circ} \mathrm{C}$ suggest the presence of $\mathrm{CH}_{4}$ and $\mathrm{N}_{2}$.

\section{Discussion}

\subsection{Timing of magmatic and hydrothermal episodes in the Puy-les-Vignes deposit}

The ${ }^{40} \mathrm{Ar} /{ }^{39} \mathrm{Ar}$ mica dates obtained in this work yield a weighted mean date of $321 \pm 2 \mathrm{Ma}(2 \sigma, \mathrm{MSWD}=1.7 ; \mathrm{n}=36)$, which falls in the same interval than the $\mathrm{U} / \mathrm{Pb}$ rutile dates. Because the closure temperature for Ar diffusion in mica (ca. $350-400^{\circ} \mathrm{C}$; Harrison et al., 2009) is much lower than $\mathrm{Pb}$ diffusion in rutile $\left(>600^{\circ} \mathrm{C}\right.$; Vry and Baker, 2006), the obtained ${ }^{40} \mathrm{Ar} /{ }^{39} \mathrm{Ar}$ mica dates correspond either to crystallization ages or to ages of isotope resetting during fluid-rock interactions. The paleodepth of formation of the Puy-les-Vignes deposit is estimated at ca. $7 \mathrm{~km}$ (see Sect. 9.2), which corresponds to regional temperatures of about $280^{\circ} \mathrm{C}$ assuming a geothermal gradient of $40^{\circ} \mathrm{C} \mathrm{km}^{-1}$ typical for continental collisional orogens (Huerta et al., 1998). The estimated temperatures are lower than the temperature of Ar retention in micas implying that magmas intruded into the regional host rocks or hydrothermal fluids circulating through will cool down rapidly by thermal conduction. Therefore, we interpret the ${ }^{40} \mathrm{Ar} /{ }^{39} \mathrm{Ar}$ mica and adularia dates obtained in this work as crystallization ages.

The earliest magmatic event at Puy-les-Vignes corresponds to the emplacement of lamprophyre dykes into the Saint-Léonard-de-Noblat gneisses at the intersection with the breccia pipe. The dated lamprophyre sample yielded a weighted mean ${ }^{40} \mathrm{Ar} /{ }^{39} \mathrm{Ar}$ biotite date of $331 \pm 14 \mathrm{Ma}$. The lower limit of this date is intersected by the dated microgranite that is known to crosscut the lamprophyre and yields a weighted mean ${ }^{40} \mathrm{Ar} /{ }^{39} \mathrm{Ar}$ muscovite date of $323 \pm 4 \mathrm{Ma}$. This indicates an episode of mantle melting between ca. 345 and ca. $327 \mathrm{Ma}$, similar to vaugnerite dykes dated at $334 \pm 1 \mathrm{Ma}$ and $336 \pm 2 \mathrm{Ma}$ in the eastern FMC (Laurent et al., 2017). The date of the microgranite falls into the age range of two-mica peraluminous granitoids from the northwestern FMC (Fig. 20), such as the Saint-Sylvestre leucogranitic complex (324 $\pm 4 \mathrm{Ma}$; Holliger et al., 1986) or the nearby Auriat granite (324 $\pm 1 \mathrm{Ma}$; Gebauer et al., 1981). Therefore, we interpret the ${ }^{40} \mathrm{Ar} /{ }^{39} \mathrm{Ar}$ muscovite date for the microgranite to represent the crystallization age. The last known magmatic event at Puy-les-Vignes corresponds to the intrusion of a RMG that yielded a weighted mean ${ }^{40} \mathrm{Ar} /{ }^{39} \mathrm{Ar}$ muscovite date of $311 \pm 5 \mathrm{Ma}$. This date falls in the same age interval of ca. $315-310 \mathrm{Ma}$ than other RMG-RMP in the Limousin (Fig. 20; Cheilletz et al., 1992; Alexandrov et al., 2000; Cuney et al., 2002; Melleton et al., 2015). Because the studied RMG lacks hydrothermal alteration features, the ${ }^{40} \mathrm{Ar} /{ }^{39} \mathrm{Ar}$ date of $311 \pm 5 \mathrm{Ma}$ is interpreted as the crystallization age.

Based on field relationships and petrographic observations, the Puy-les-Vignes breccia pipe results from a multistage hydrothermal evolution. The ${ }^{40} \mathrm{Ar} /{ }^{39} \mathrm{Ar}$ dates of $324 \pm 5 \mathrm{Ma}$ and $318 \pm 5 \mathrm{Ma}$ on hydrothermal muscovite and the $\mathrm{U} / \mathrm{Pb}$ dates on rutile of $322 \pm 10 \mathrm{Ma}$ and $323 \pm 5 \mathrm{Ma}$ from stages I and II overlap between ca. 323 and ca. $318 \mathrm{Ma}$ (Fig. 20). These ages are consistent with the ${ }^{40} \mathrm{Ar} /{ }^{39} \mathrm{Ar}$ plateau age of $323 \pm 2 \mathrm{Ma}$ obtained on a muscovite interpreted to be prior or coeval to wolframite deposition (Cuney et al., 2002). U/Pb dating of wolframite yielded a concordia age of $317.7 \pm 0.7 \mathrm{Ma}$ (Harlaux et al., 2018a), which is compatible with the previous ages and points toward a $\mathrm{W}$ mineralization episode at ca. $318 \mathrm{Ma}$. The period of ca. 325 to ca. $315 \mathrm{Ma}$ is synchronous to the emplacement of two-mica peraluminous leucogranites in the Limousin such as the La Porcherie granite $(317 \pm 3 \mathrm{Ma}$; Lafon and Respaut, 1988), the Courcelles granite $(318 \pm 3 \mathrm{Ma}$; Cartannaz et al., 2007), the Glény granite $(318 \pm 3 \mathrm{Ma}$; Faure et al., 2009b), the Pradines granite (313 $\pm 4 \mathrm{Ma}$; Gébelin et al., $2009)$, and the Livradois granite $(315 \pm 4 \mathrm{Ma}$; Gardien et al., 2011). Crustal melting was coeval with high-temperature and low-pressure metamorphism as evidenced by cordieritesillimanite migmatites that formed at $315 \pm 5 \mathrm{Ma}$ and $316 \pm 2 \mathrm{Ma}$ along the western border of the Millevaches leucogranitic complex (Gébelin et al., 2009). The ${ }^{40} \mathrm{Ar} /{ }^{39} \mathrm{Ar}$ adularia date of $302 \pm 4 \mathrm{Ma}$ (stage IV) records a late hydrothermal episode that is temporally disconnected from previous stages. This age is synchronous with the cooling and exhumation of the Limousin metamorphic basement at ca. 305-300 Ma (Scaillet et al., 1996a; Le Carlier de Veslud et al., 2013) related to the late- to post-orogenic uplift and generalized extension of the FMC (Faure et al., 2009a). The $\mathrm{Bi} \pm \mathrm{Au}-\mathrm{Ag}$ assemblage (stage $\mathrm{V}$ ) was therefore formed during or after the 305-300 Ma period coevally with late Carboniferous orogenic gold deposits in the FMC, which share similar mineralogical features and result from the mixing of metamorphic and meteoric fluids (Boiron et al., 2003; Bouchot et al., 2005). 


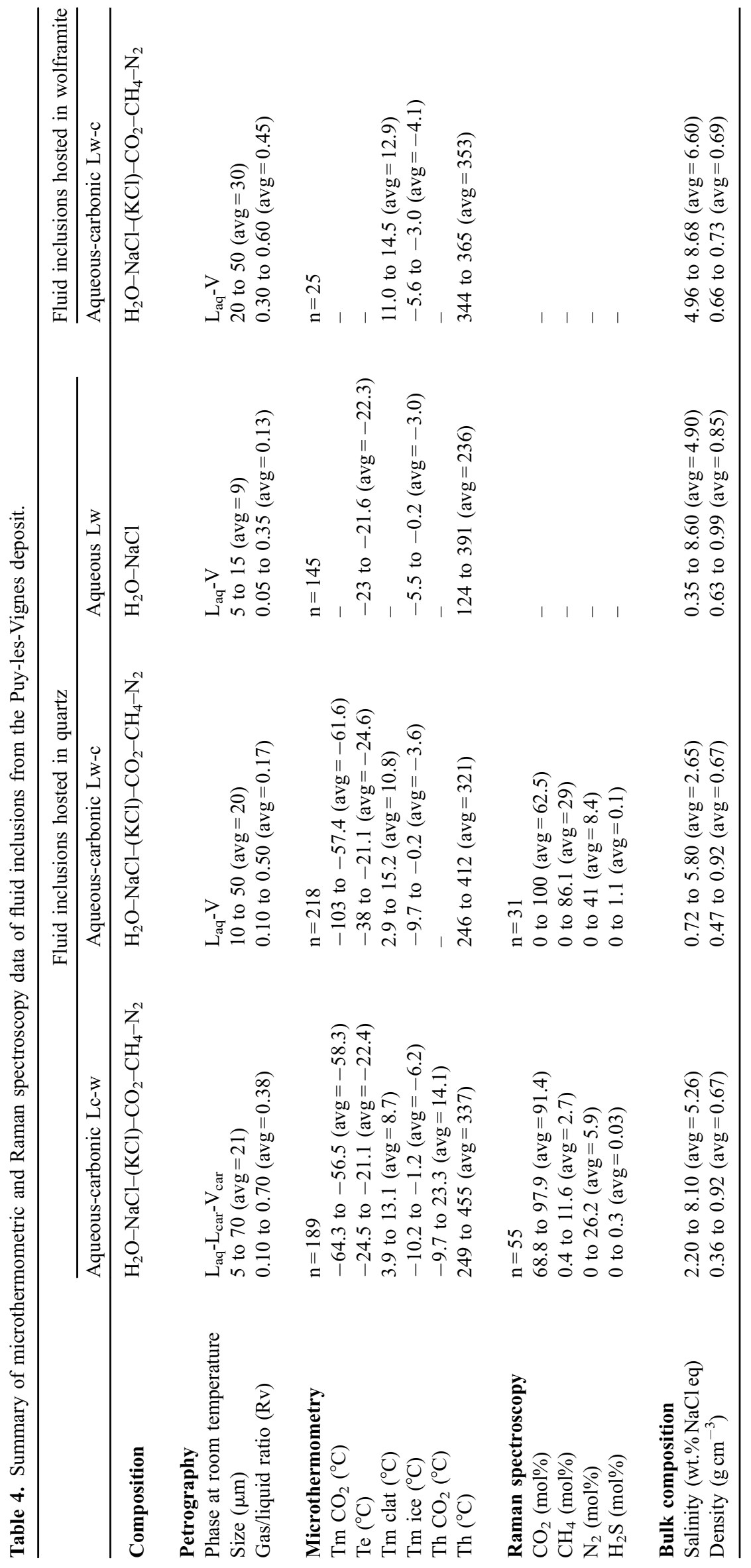

Page 28 of 44 

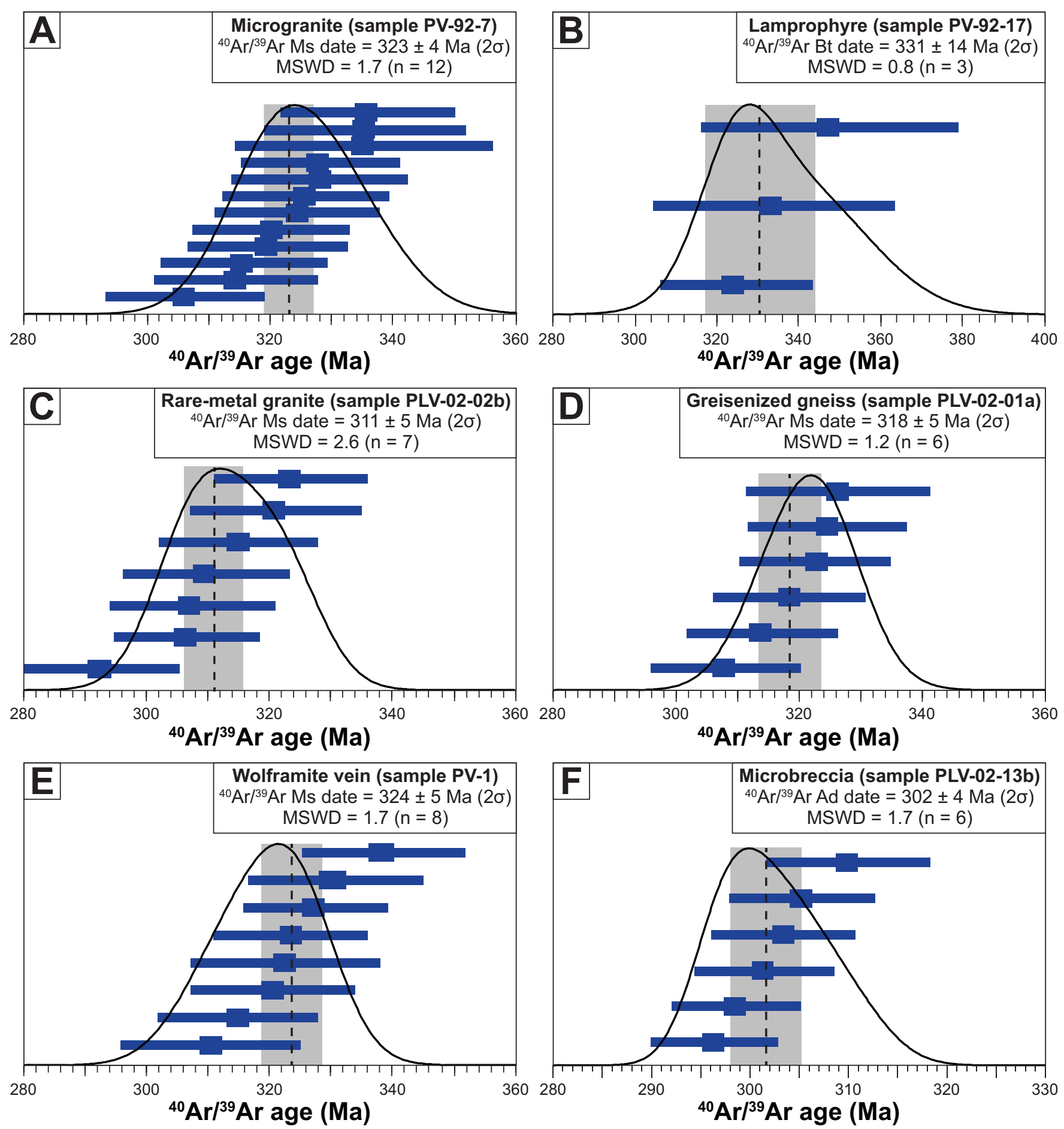

Fig. 16. ${ }^{40} \mathrm{Ar} /{ }^{39} \mathrm{Ar}$ weighted mean ages obtained for micas and adularia from the Puy-les-Vignes deposit. Blue lines represent apparent age calculated for each individual ${ }^{40} \mathrm{Ar} /{ }^{39} \mathrm{Ar}$ analysis. Black curves represent the probability density distribution of the data. Error bars are reported at $2 \sigma$ level of uncertainty. ${ }^{40} \mathrm{Ar} /{ }^{39} \mathrm{Ar}$ isotopic data are reported in Table 3.

\subsection{Nature and pressure-temperature conditions of the mineralizing fluids}

The W-mineralizing fluids in the Puy-les-Vignes deposit are characterized by a low to moderate salinity $(0.7-8.7 \mathrm{wt} . \%$ $\mathrm{NaCl}$ eq), elevated homogenization temperatures $\left(250-455^{\circ} \mathrm{C}\right)$, and high contents of $\mathrm{CO}_{2}(\mathrm{avg}=10 \mathrm{~mol} \%), \mathrm{CH}_{4}(\mathrm{avg}=1.6 \mathrm{~mol} \%)$, and $\mathrm{N}_{2}(\mathrm{avg}=1.1 \mathrm{~mol} \%)$. These fluid compositions belong to the $\mathrm{C}-\mathrm{O}-\mathrm{H}-\mathrm{N}$ system and are similar to other peri-granitic W-Sn deposits in the FMC (Ramboz et al., 1985; Bril and Beaufort, 1989; Cuney et al., 1992; Lerouge et al., 2000; Vallance et al., 2001). Similar C-O-H-N fluids have been 

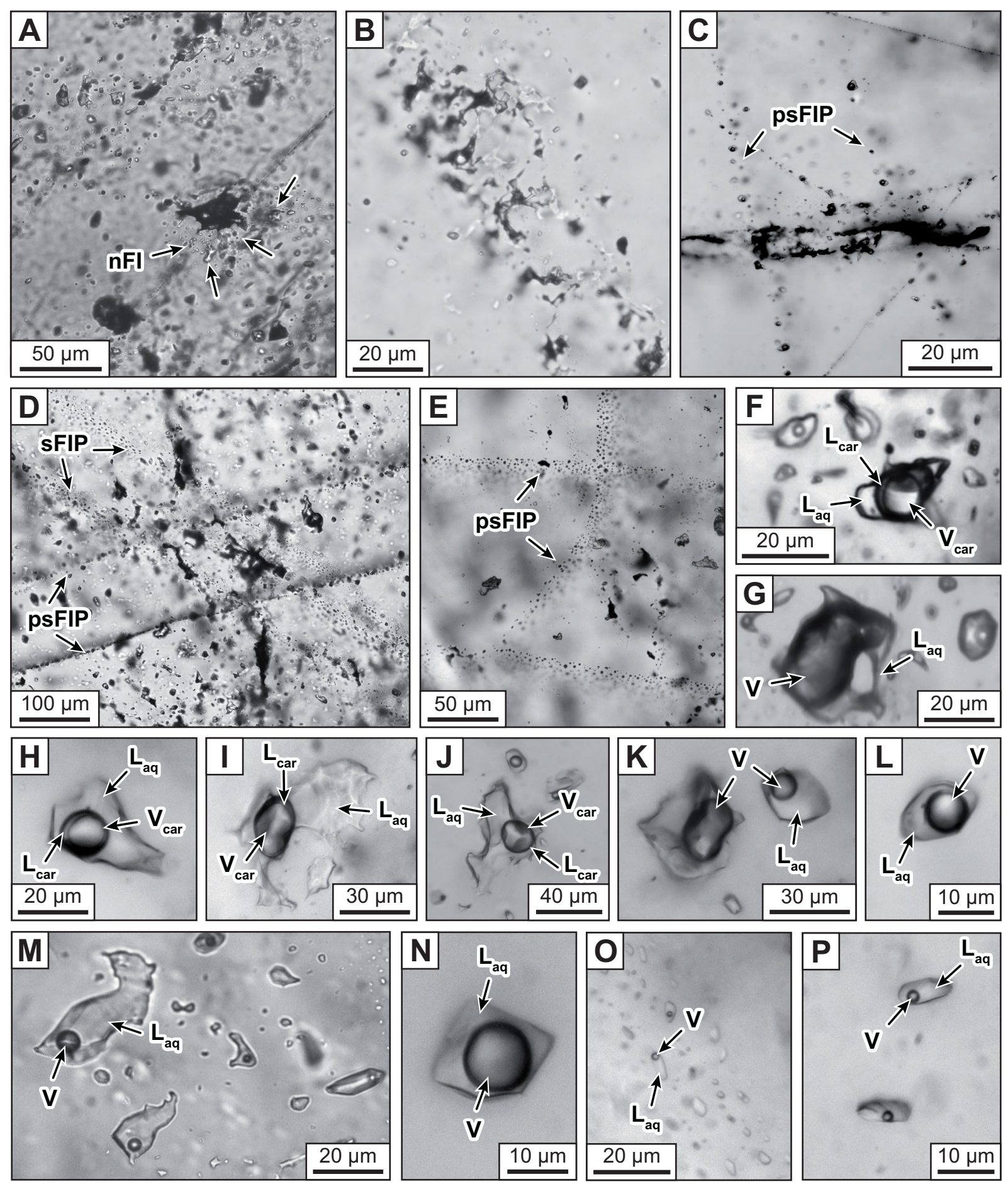

Fig. 17. Transmitted light photomicrographs of fluid inclusions (FIs) hosted in wolframite-bearing quartz veins from the Puy-les-Vignes deposit (sample PLV-7591, “filon 2"; sample PV-1, “filon T18”). (A) Isolated primary Lc-w surrounded by a halo of small neonate fluid inclusions (nFI) resulting from post-entrapment reequilibration. (B) Elongated cluster of decrepitated FIs possibly located at a growth zone boundary. (C) Cluster of decrepitated primary FIs cut by two pseudosecondary (ps) fluid inclusion planes (FIP) of regular Lw-c. (D) Clusters of partly decrepitated Lc-w cut by pseudosecondary FIP of partly decrepitated Lw-c and by secondary (s) FIP of regular Lw. (E) Pseudosecondary FIP of Lw-c, partly decrepitated, located at grain boundaries. $(\mathrm{F})$ Isolated irregular three-phase $\mathrm{Lc}-\mathrm{w}$ containing a carbonic liquid phase $\left(\mathrm{L}_{\text {car }}\right)$, a carbonic vapor phase $\left(\mathrm{V}_{\text {car }}\right)$, and an aqueous liquid phase $\left(\mathrm{L}_{\mathrm{aq}}\right)$. $(\mathrm{G})$ Very irregular two-phase FI showing an "atoll-like" stretching texture. $(\mathrm{H})$ Isolated regular three-phase Lc-w. (I) Highly irregular three-phase Lc-w. (J) Isolated irregular three-phase Lc-w. (K) Two-phase Lw-c having variable vapor to liquid ratios. (L) Regular two-phase Lw-c along a pseudosecondary FIP. (M) Cluster of irregular two-phase Lw-c (sample PLV-02-12). (N) Isolated regular two-phase Lw-c. (O) Secondary FIP of regular two-phase Lw. (P) Regular two-phase Lw along a secondary FIP. 

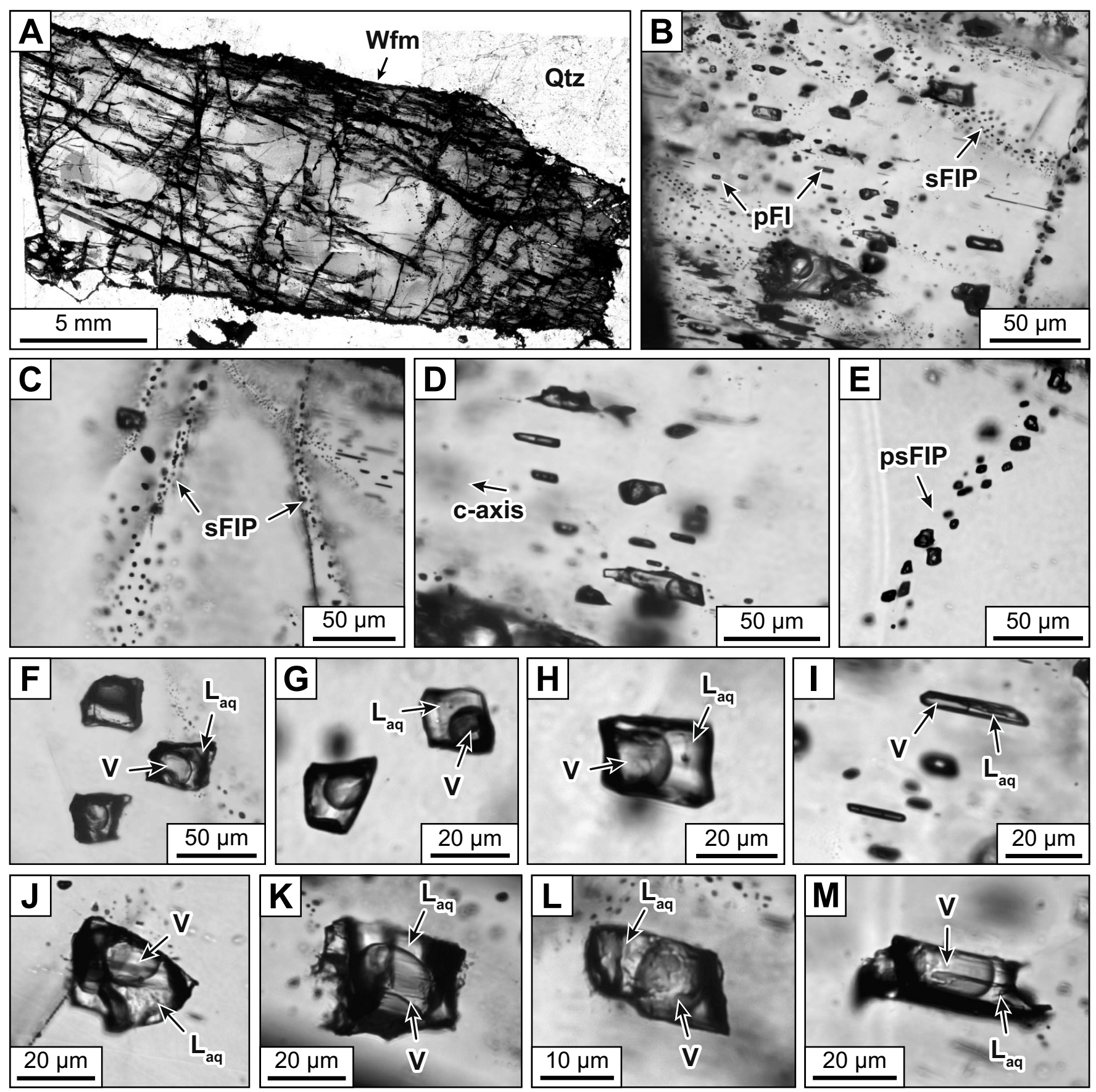

Fig. 18. Near-infrared (NIR) transmitted light photomicrographs of fluid inclusions (FIs) hosted in wolframite from the Puy-les-Vignes deposit (sample PLV-7591, "filon 2"). (A) Global view of the studied euhedral wolframite (Wfm) crystal hosted in quartz (Qtz). (B) Intracrystalline zone showing numerous primary (p) and secondary (s) FIs. (C) Secondary fluid inclusion planes (FIP) of Lw having negative crystal shapes crosscutting wolframite. (D) Primary Lw-c aligned along the c-axis of wolframite. (E) Pseudo-secondary (ps) FIP of Lw-c showing regular to slightly irregular shapes. (F-M) Representative two-phase Lw-c showing variable shapes and containing a vapor phase (V) and an aqueous liquid phase $\left(\mathrm{L}_{\mathrm{aq}}\right)$.

described in other Variscan W-Sn deposits (Noronha et al., 1992; Vindel et al., 1995; Chicharro et al., 2016), in evolved pegmatites and leucogranites (Charoy and Noronha, 1996; Fuertes-Fuente et al., 2000; Bakker and Schilli, 2016), and in metamorphic environments (Van den Kerkhof et al., 1991; Guedes et al., 2002; Boiron et al., 2007). The presence of $\mathrm{CO}_{2}$ and $\mathrm{CH}_{4}$ in FIs can result from different mechanisms including high-temperature graphite-water interactions in metasediments (Ramboz et al., 1985; Dubessy et al., 1989), degassing or flushing of $\mathrm{CO}_{2}$ from silicate melts (Lowenstern, 2001; Blundy et al., 2010), $\mathrm{CO}_{2}$ reduction by hydrogen (Hall and Bodnar, 1990), or boron complexing in aqueous-carbonic fluid (Huff and 

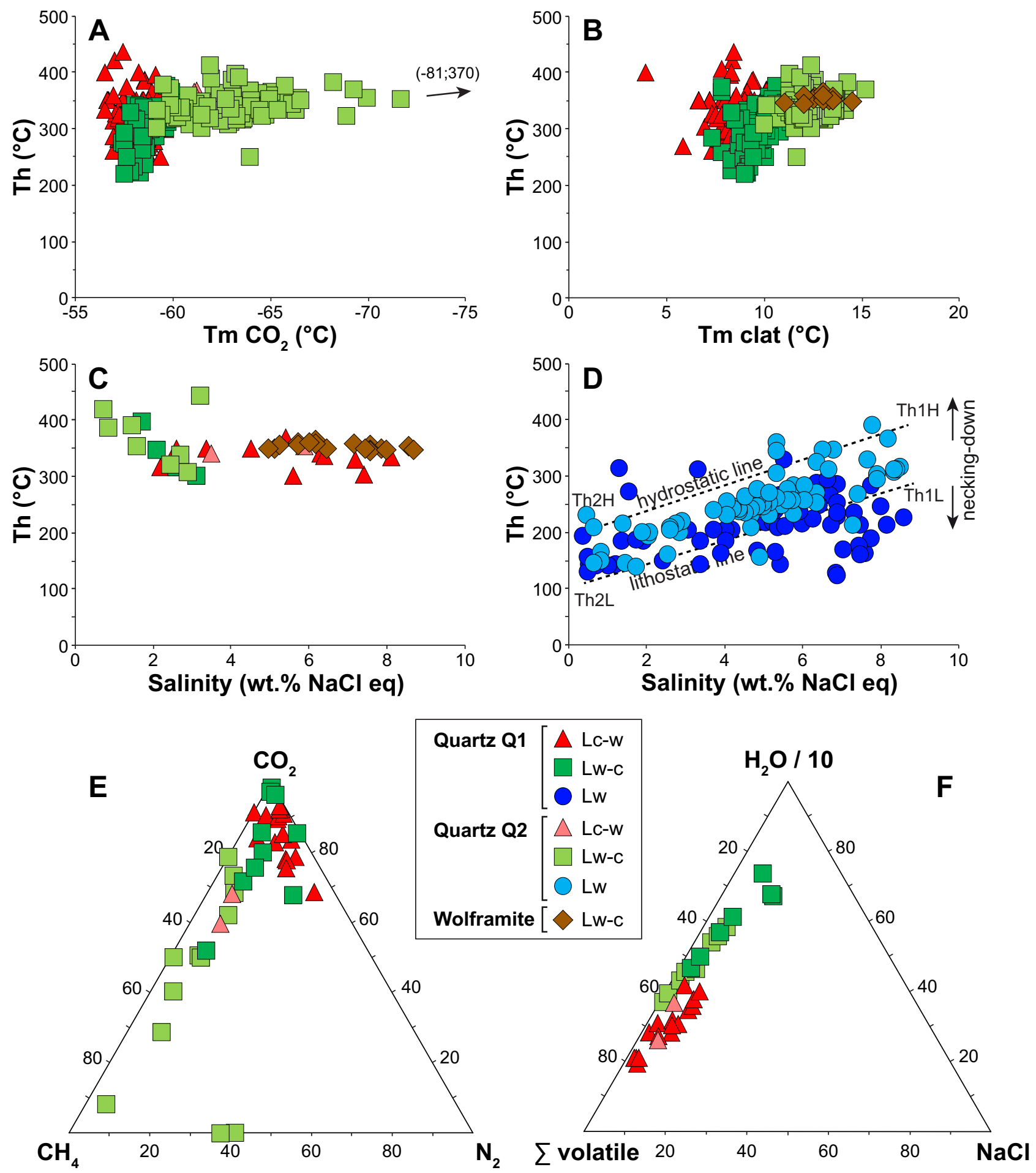

Fig. 19. Compositions of fluid inclusions from the Puy-les-Vignes deposit determined by microthermometry and Raman spectroscopy. (A-C) Homogenization temperature for the Lc-w and Lw-c hosted in quartz and wolframite as function of the $\mathrm{CO}_{2}$ melting temperature ( $\mathrm{Tm} \mathrm{CO} \mathrm{CO}_{2}$ ), the clathrate melting temperature (Tm clat), and salinity. (D) Homogenization temperature for the Lw hosted in quartz as function of salinity. (E) Volatile composition of the gas phase of Lc-w and Lw-c plotted in the $\mathrm{CO}_{2}-\mathrm{CH}_{4}-\mathrm{N}_{2}$ ternary diagram. (F) Bulk composition of Lc-w and Lw-c plotted in the $\mathrm{H}_{2} \mathrm{O} / 10-\sum$ volatile- $\mathrm{NaCl}$ ternary diagram. 
Nabelek, 2007). The release of $\mathrm{N}_{2}$ can originate from the breakdown of $\mathrm{NH}_{4}^{+}$-bearing mica and feldspar during dehydration-melting of metasediments (Moine et al., 1994; Bebout et al., 1999; Pitcairn et al., 2005) or from strongly reduced silicate melts (Boulliung et al., 2020).

Raman spectroscopy data of FIs from Puy-les-Vignes show an evolutionary trend between a $\mathrm{CO}_{2}\left(>\mathrm{CH}_{4}\right)$-rich fluid endmember and $\mathrm{CH}_{4}\left(>\mathrm{CO}_{2}\right)$-rich fluid endmember from Q1 to Q2 (Fig. 19E), which is compatible with decreasing temperatures of the graphite-water equilibrium from $>550{ }^{\circ} \mathrm{C}$ to $400{ }^{\circ} \mathrm{C}$ (Huizenga, 2001). While the relatively high $\mathrm{N}_{2}$ content of FIs could indicate a metamorphic component in the hydrothermal system, the variable $\mathrm{CH}_{4}$ to $\mathrm{N}_{2}$ ratios suggest a two-component origin. Therefore, we interpret the $\mathrm{C}-\mathrm{O}-\mathrm{H}-\mathrm{N}$ fluid compositions as resulting from a moderate-salinity $\left(>9\right.$ wt. $\% \mathrm{NaCl}$ eq) and high-temperature $\left(>450{ }^{\circ} \mathrm{C}\right)$ hydrothermal fluid that interacted with volatile-rich metasedimentary rocks and/or that mixed with low-salinity metamorphic fluids equilibrated with such rocks. The Lw show a trend of decreasing salinity (from $>8.0$ to $<0.5 \mathrm{wt} . \% \mathrm{NaCl}$ eq) with decreasing temperature (from $>350$ to $<150{ }^{\circ} \mathrm{C}$ ), which is interpreted as a cooling-dilution trend (Fig. 19D). The Th variations for a given composition are interpreted as recording anisothermal mixing under fluctuating pressure conditions from lithostatic to hydrostatic (Dubessy et al., 2003) and partially disturbed by post-entrapment reequilibration (e.g., necking-down). Two fluid endmembers are involved in the mixing, i.e. a high-temperature $\left(>350^{\circ} \mathrm{C}\right)$ and moderatesalinity ( $>9 \mathrm{wt} . \% \mathrm{NaCl}$ eq) fluid $\mathrm{L} 1$, similar to the mineralizing fluids from the stages II and III, and a low-temperature $\left(<150{ }^{\circ} \mathrm{C}\right)$ and low-salinity $(<0.5 \mathrm{wt} . \% \mathrm{NaCl}$ eq $)$ fluid $\mathrm{L} 2$, possibly of meteoric origin.

Pressure-temperature conditions of the Puy-les-Vignes deposit were reconstructed based on representative isochores (Fig. 21). No boiling assemblages were observed in the FI inventory, which precludes determining directly entrapment pressures based on homogenization temperatures. In Q1, two families of isochores are distinguished for the Lc-w and Lw-c (Fig. 21A): (i) high-angle isochores corresponding mostly to the regular and small FIs; and (ii) low-angle isochores corresponding to the majority of irregular and large FIs showing reequilibration features and to large and regular FIs. The two sets of isochores intersect geothermal gradients at $60-70{ }^{\circ} \mathrm{C} \mathrm{km}^{-1}$ for trapping temperatures of ca. $400-450{ }^{\circ} \mathrm{C}$ and pressure variations from ca. $190 \mathrm{MPa}$ (lithostatic) to ca. $70 \mathrm{MPa}$ (hydrostatic). These pressure estimates indicate that the Puy-les-Vignes deposit formed at a paleodepth of ca. $7 \mathrm{~km}$. Similar trapping conditions are estimated for the Lw-c hosted in wolframite. The pressure variations, from lithostatic to hydrostatic, are interpreted to result from the hydraulic fracturing of the host rocks during the breccia pipe formation. The differential pressure of $120 \mathrm{MPa}$ between the lithostatic and hydrostatic gradients is equal to the minimum $\Delta \mathrm{P}$ required to reequilibrate a $20 \mu \mathrm{m}$ diameter FI hosted in quartz (Bodnar et al., 1989). Trapping temperatures are more than $100^{\circ} \mathrm{C}$ lower than those calculated by the $\mathrm{Zr}$-in-rutile thermometer of $546 \pm 32^{\circ} \mathrm{C}$, suggesting that hydrothermal rutile yields overestimated temperatures, as also documented by Cabral et al. (2015). Representative isochores for the Lc-w and Lw-c hosted in Q2 yield similar trapping conditions of ca. $400-420^{\circ} \mathrm{C}$ and pressure fluctuations from ca. $190 \mathrm{MPa}$ (lithostatic) to ca. $70 \mathrm{MPa}$ (hydrostatic) for high geothermal gradients of $60-70{ }^{\circ} \mathrm{C} \mathrm{km}^{-1}$ (Fig. 21B). Pressure variations from ca. $135 \mathrm{MPa}$ (lithostatic) to ca. $50 \mathrm{MPa}$ (hydrostatic) are estimated for trapping of the $\mathrm{Lw}$, when the same $\Delta \mathrm{P}$ is encountered for the $\mathrm{L} 1\left(380^{\circ} \mathrm{C}\right.$ with a $70{ }^{\circ} \mathrm{C} \mathrm{km}^{-1}$ gradient $)$ and $\mathrm{L} 2\left(210^{\circ} \mathrm{C}\right.$ with a $40^{\circ} \mathrm{C} \mathrm{km}^{-1}$ gradient $)$ fluid endmembers (Fig. 21C). This would correspond to a paleodepth of ca. $5 \mathrm{~km}$ for trapping of Lw. Compared to previous stages, the Lw records a decrease of the reservoir depth (from 7 to $5 \mathrm{~km}$ ) likely related to an increased exhumation. Assuming an erosion rate of $0.5-1.0 \mathrm{~mm} \mathrm{yr}^{-1}$, representative for the exhumation of the Variscan basement during the late Carboniferous (Scaillet et al., 1996b; Schulmann et al., 2002), the erosion of $2 \mathrm{~km}$ of rock thickness between the stage II and the Lw stage would require between 2 and $4 \mathrm{My}$. Considering that the $\mathrm{W}$ mineralization formed at ca. $318 \mathrm{Ma}$, the Lw would have been trapped between 314 and $316 \mathrm{Ma}$. The Lw represent, therefore, a late stage in the Puy-les-Vignes hydrothermal system, which possibly records the infiltration of meteoric waters during the late Carboniferous uplift of the FMC, as also evidenced in other W-Sn deposits (Vallance et al., 2001) and orogenic Au deposits (Boiron et al., 2003) from the Limousin area.

\subsection{Hydrothermal fluid origin and wolframite precipitation}

The Puy-les-Vignes breccia pipe resulted from intense hydrofracturing of the Saint-Léonard-de-Noblat gneiss unit caused by ascending overpressured hydrothermal fluids, as evidenced by characteristic textures of hydraulic brecciation and fluid-assisted rotation of metric-size clasts (Jébrak, 1997). Wolframite from Puy-les-Vignes shows similar trace element composition than evolved peraluminous granites from the FMC (Harlaux et al., 2018b), suggesting that W and other metals were likely sourced from an unexposed leucogranite located beneath the breccia pipe. Tungsten could be released either by magmatic fluids due to elevated fluid-melt-crystal partitioning coefficients (Hulsbosch et al., 2016; Schmidt et al., 2020) or by metamorphic fluids during high-temperature interactions with a two-mica leucogranite (Vallance et al., 2001; El Korh et al., 2020; Carocci et al., 2021). The role of fluid-rock interactions is supported by the chemical and boron isotope compositions of tourmaline that are compatible with both a magmatic and a metamorphic fluid source (Harlaux et al., 2019) as well as by the Fe-dominated composition of wolframite (Michaud and Pichavant, 2019). The origin of the hydrothermal fluids (magmatic vs. metamorphic) can be further discussed based on estimation of the volume of fluids required for precipitation of quartz and wolframite (Supplementary Table 7). Considering an elliptic surface of dimensions $340 \times 80 \mathrm{~m}$ and a vertical extension of $600 \mathrm{~m}$ (i.e., twice the known height) for the breccia pipe, the total volume of rock would be of $5.1 \times 10^{7} \mathrm{~m}^{3}$. Assuming that quartz represents about $10 \%$ of the total volume of the breccia (Weppe, 1951, 1958), a mass of $1.3 \times 10^{10} \mathrm{~kg}$ of quartz can be estimated. Taking into account a quartz solubility $55 \mathrm{mmol} \mathrm{kg}^{-1}$ for a hydrothermal fluid at $10 \mathrm{wt} . \% \mathrm{NaCl}$ eq, $500{ }^{\circ} \mathrm{C}$ and $100 \mathrm{MPa}$ (Monecke et al., 2018) and an average fluid xdensity of $0.67 \mathrm{~g} \mathrm{~cm}^{-3}$, we estimate a volume of fluids of $6.1 \times 10^{9} \mathrm{~m}^{3}\left(6.1 \mathrm{~km}^{3}\right)$. Following the same reasoning for 


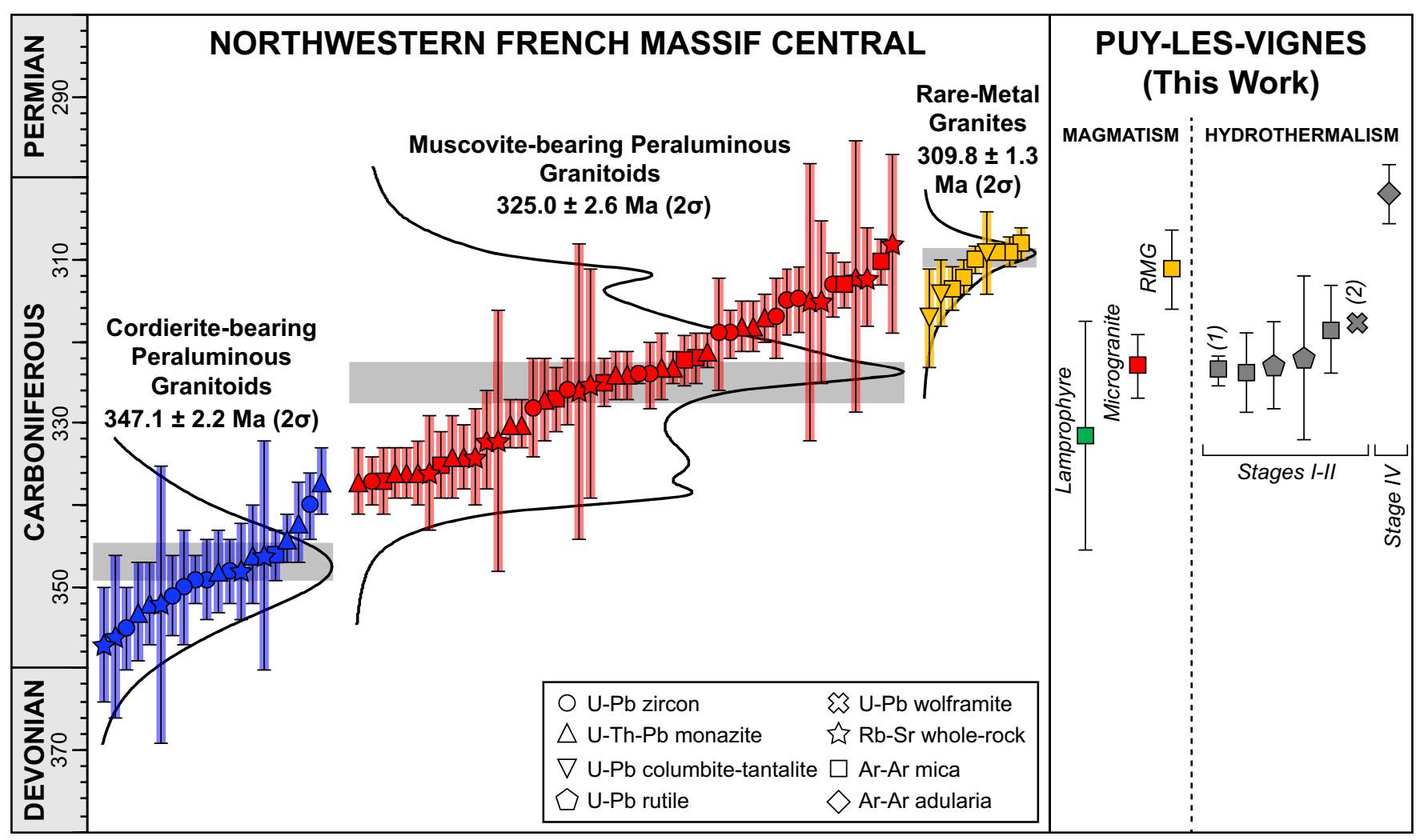

Fig. 20. Summary of geochronological data for the Puy-les-Vignes deposit and comparison with published ages of peraluminous granitoids from the northwestern French Massif Central. Errors are reported at $2 \sigma$ level of uncertainty. Black curves represent the probability density distribution of integrated ages. Data sources for the granitoids: Duthou (1978), Berthier et al. (1979), Gebauer et al. (1981), Duthou et al. (1984), Holliger et al. (1986), Lafon and Respaut (1988), Cheilletz et al. (1992), Cuney et al. (1993), Roig et al. (1996, 2002), Alexandrov et al. (2000), Bertrand et al. (2001), Alexandre et al. (2002), Gébelin (2004), Cartannaz (2005), Cartannaz et al. (2007), Gébelin et al. (2007, 2009), Joly et al. (2007), Rolin et al. (2009, 2014), Faure et al. (2009b), Gardien et al. (2011), Thiéry and Rolin (2012), Melleton et al. (2015). Data sources for Puy-lesVignes: (1) Cuney et al. (2002), (2) Harlaux et al. (2018a).

wolframite, we can estimate a volume of fluids of $1.6 \times 10^{8} \mathrm{~m}^{3}$ $\left(0.16 \mathrm{~km}^{3}\right)$ by assuming an average grade of $0.5 \% \mathrm{WO}_{3}$ and considering a W solubility of $500 \mathrm{ppm}$ for a fluid at $10 \mathrm{wt}$. $\% \mathrm{NaCl}$ eq, $500{ }^{\circ} \mathrm{C}$, and $100 \mathrm{MPa}$ (Wood and Samson, 2000). Therefore, the minimum volume of hydrothermal fluids required for the formation of the wolframite-bearing breccia pipe would be of about $6.2 \mathrm{~km}^{3}$. It is noteworthy that these calculations assume $100 \%$ efficiency of mineral precipitation and no fluid loss in the host rocks, implying that the volume of fluids involved should be larger than this estimation.

1 Magmatic fluid origin: Assuming that the volume of fluids of $6.2 \mathrm{~km}^{3}$ was entirely produced by a water-saturated intrusion containing an initial water content of $5 \mathrm{wt} . \%$, this would require a minimum volume of melt of ca. $36 \mathrm{~km}^{3}$ for an average melt density of $2.3 \mathrm{~g} \mathrm{~cm}^{-3}$ (Supplementary Table 7). Considering a volume contraction of $10 \%$ from liquidus to solidus (Bea, 2010), this would correspond to a volume of granite of $33 \mathrm{~km}^{3}$, i.e., a pluton of dimensions $1.5 \times 4.7 \times 4.7 \mathrm{~km}$. Fluids that exsolve from an intrusion at a depth $>6 \mathrm{~km}$ (corresponding to a lithostatic pressure $>150 \mathrm{MPa}$ ) are in the single-phase domain at magmatic conditions and remain in this state during cooling to $500^{\circ} \mathrm{C}$ (Driesner and Heinrich, 2007). Consequently, fluids trapped at these pressure-temperature conditions have a moderate salinity (ca. $10 \mathrm{wt} . \% \mathrm{NaCl}$ eq), an intermediate density (ca. $0.6 \mathrm{~g} \mathrm{~cm}^{-3}$ ) and do not undergo boiling. This model explains the absence of coexisting vapor and hypersaline fluid inclusions (boiling assemblage), the moderate fluid salinity ( $<9 \mathrm{wt} . \% \mathrm{NaCl}$ eq), as well as the high geothermal gradients of $60-70^{\circ} \mathrm{C} \mathrm{km}^{-1}$ determined from the $\mathrm{P}-\mathrm{T}$ reconstruction. The overpressures generated by the exsolved magmatic fluids could be a mechanism for the hydraulic brecciation of the host rocks, as generally proposed for the formation of breccia pipes (Burnham, 1985; Sillitoe, 1985; Jébrak, 1997). The high $\mathrm{CO}_{2}$ content (avg $=10 \mathrm{~mol} \%$ ) determined in FIs fall in the same range than magmatic fluids from porphyry systems (Kouzmanov and Pokrovski, 2012). In this scenario, magmatic fluids exsolved from an evolved leucogranite would have interacted with volatile-rich metamorphic rocks resulting in the cooling, dilution, and enrichment in metamorphic-derived volatiles (mainly $\mathrm{CH}_{4}$ and $\mathrm{N}_{2}$ ). The main limitation of this model is the volume of fluids required since numerical modelling shows that magmatic fluids are released by successive pulses from crystallizing intrusions (Weis et al., 2012; 

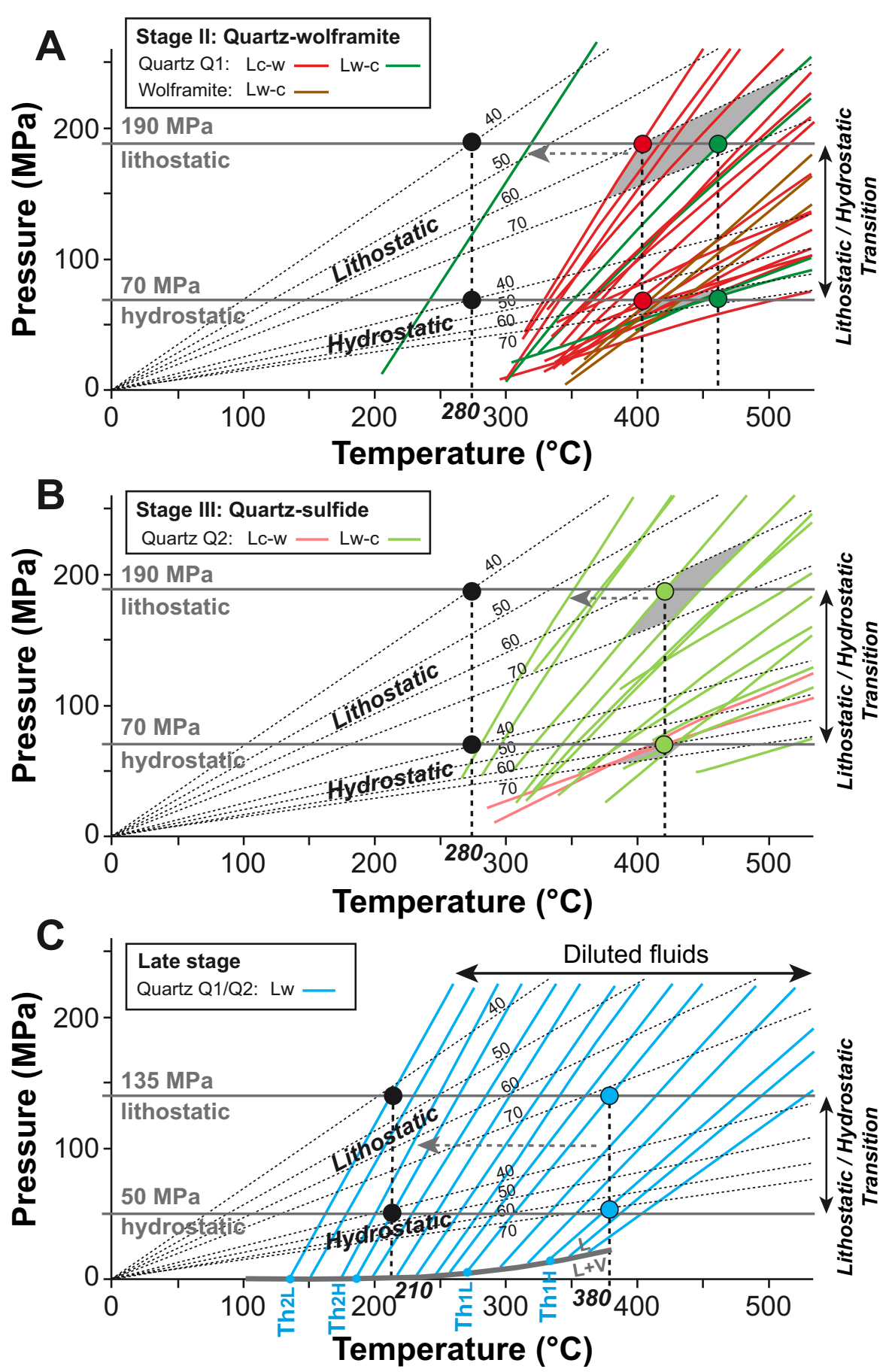

Fig. 21. Pressure-temperature reconstruction of the fluid conditions in the Puy-les-Vignes deposit. (A) Representative isochores for the Lc-w and Lw-c fluid inclusions trapped in quartz Q1 and wolframite from the stage II. (B) Representative isochores for the Lc-w and Lw-c fluid inclusions trapped in quartz Q2 from the stage III. (C) Representative isochores for the Lw fluid inclusions trapped in quartz Q1 and Q2 during a late stage. Lithostatic and hydrostatic geothermal gradients between 40 and $70{ }^{\circ} \mathrm{C} \mathrm{km}^{-1}$ are shown for comparison.

Lamy-Chappuis et al., 2020). This would imply a much larger volume of granitic melt that the one estimated in order to supply in a single time the volume of fluids required to generate the breccia pipe.

2 Metamorphic fluid origin: Considering that the fluids were produced by devolatilization reactions of volatile-rich metasedimentary rocks, the question arises about the source reservoir. The LGU hosting the Puy-les-Vignes deposit experienced migmatization during the Middle Devonian (385-375 Ma) at metamorphic conditions of $650-750^{\circ} \mathrm{C}$ and $700 \mathrm{MPa}$ ("D1 event" of Faure et al., 2009a) implying the muscovite- and biotite-breakdown reactions. Consequently, the LGU paragneisses cannot be a local source of metamorphic fluids at $318 \mathrm{Ma}$. In contrast, 

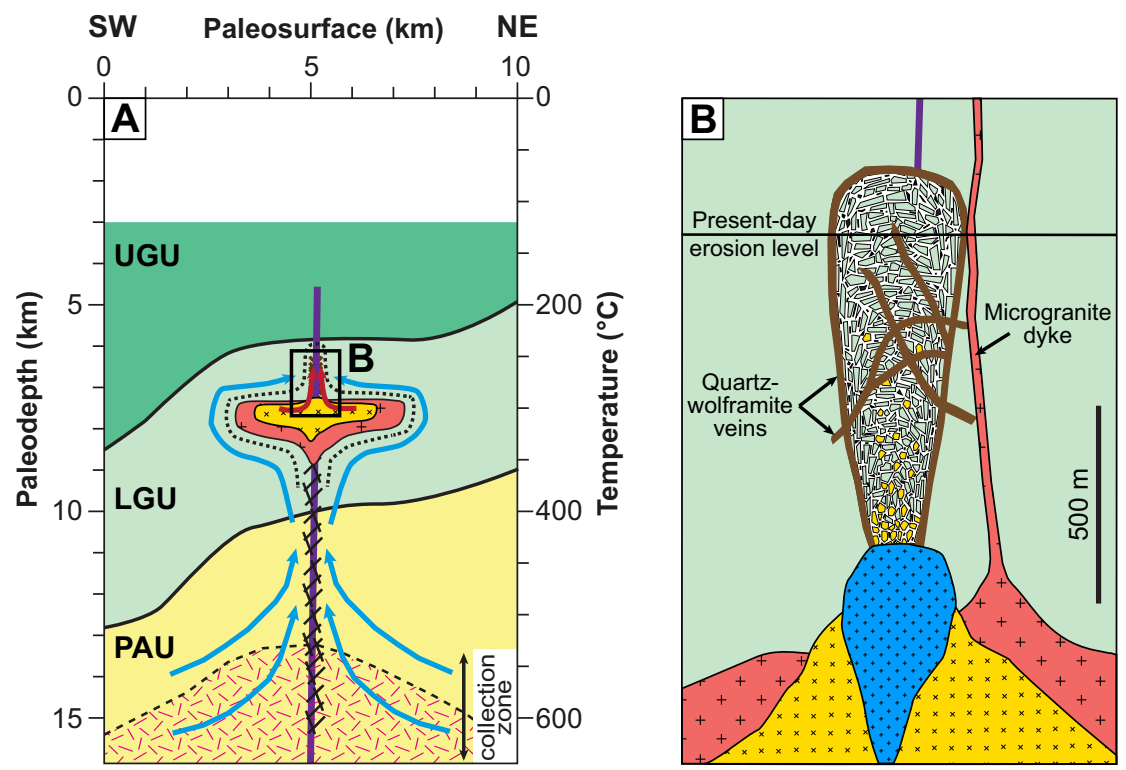

\begin{tabular}{|lll|}
\hline Deep fault zone & Rare-metal granite (ca. 311 Ma) \\
Breccia pipe & Magmatic fluids & Evolved leucogranite (ca. 318 Ma) \\
Metamorphic fluids & + & Peraluminous granite (ca. 324 Ma) \\
..... Isotherm $450^{\circ} \mathrm{C}$ & HT-LP metamorphic domain \\
\hline
\end{tabular}

Fig. 22. Conceptual model of the Puy-les-Vignes ore-forming hydrothermal system. (A) Crustal-scale model showing the stack of metamorphic nappes (UGU = Upper Gneiss Unit, LGU = Lower Gneiss Unit, PAU = Para-Autochtonous Unit) in the Limousin area. The formation of the W breccia pipe results from a W-rich magmatic fluid that exsolved from an evolved leucogranite and interacted with volatile-rich metasedimentary country rocks and/or possibly mixed with low-salinity metamorphic fluids issued from devolatilization of deep-seated metasediments. The estimated temperatures correspond to a regional geothermal gradient of $40{ }^{\circ} \mathrm{C} \mathrm{km}^{-1}$. (B) Schematic cross-section of the Puy-les-Vignes breccia pipe showing the superimposition of three concealed granitic intrusions: (i) a peraluminous granite emplaced at ca. $324 \mathrm{Ma}$ generating microgranite dykes exposed at the present-day surface, (ii) an evolved leucogranite emplaced at ca. 318 Ma yielding the formation of the quartzsupported breccia pipe and wolframite-bearing quartz veins, and (iii) a rare-metal granite emplaced at ca. 311 Ma that produced a disseminated magmatic-hydrothermal $\mathrm{Nb}-\mathrm{Ta}$ mineralization overprinting the $\mathrm{W}$-mineralized system.

the PAU, structurally located below the LGU, never experienced the D1 metamorphism nor migmatization and records maximum metamorphic conditions of $500-600^{\circ} \mathrm{C}$ and 700-800 MPa (Do Couto et al., 2016) during the early Carboniferous (360-350 Ma; "D2 event" of Faure et al., 2009a). Thus, the PAU micaschists underlying the LGU gneisses may represent a distal source of metamorphic fluids produced by high-temperature and low-pressure metamorphism during the late Carboniferous (320-315 Ma). Deep metamorphic fluids could be gathered into a collection zone, then focused and channelized in a midcrustal fault zone, ascending at high rates up to a dispersion region in cooler rocks (Thompson and Connolly, 1992; Connolly, 1997; Carocci et al., 2021). The half-width of both collection and dispersion zones is typically in the $3-5 \mathrm{~km}$ range, and the height of the system is on the order of 10 to $15 \mathrm{~km}$. This model accounts for the high volume of fluids required, the upward heat advection, and the high $\mathrm{CO}_{2}-\mathrm{CH}_{4}-\mathrm{N}_{2}$ contents of the fluids. The rapid and adiabatic ascending of pressurized volatile-rich fluids along a crustal fault zone under the LGU carapace may represent a mechanism for generating hydraulic fracturing of the host rocks. The main limitation of this model is that devolatilization of graphite-rich pelitic metasediments only produce low-salinity (typically $<5$ wt. $\% \mathrm{NaCl}$ eq) metamorphic fluids (Guedes et al., 2002; Yardley and Graham, 2002).

Based on available data, we favor an intermediate model involving a W-rich intermediate-density magmatic fluid that exsolved from an evolved leucogranite and interacted with the volatile-rich metasedimentary country rocks and/or possibly mixed with low-salinity metamorphic fluids of deep origin (Fig. 22). Experimental works and thermodynamic modelling show that the solubility of wolframite in hydrothermal fluids increases with increasing temperature and salinity and with decreasing $\mathrm{pH}$ and $\mathrm{Fe}$ contents of the fluid (Wood and Samson, 2000; Wang et al., 2019). Addition of non-polar molecules such as $\mathrm{N}_{2}, \mathrm{CO}_{2}$, and $\mathrm{CH}_{4}$ yields a decrease of $\mathrm{W}$ concentration in solution (Dubessy et al., 1989; Gibert et al., 1992). Precipitation of wolframite at Puyles-Vignes could have been triggered by several processes including cooling, depressurization, fluid mixing, and fluidrock interaction (Heinrich, 1990; Wei et al., 2012; Dewaele et al., 2016; Chicharro et al., 2016; Lecumberri-Sanchez et al., 2017; Legros et al., 2019, 2020; Monnier et al., 2020). 
In particular, fluid pressure drop induced by hydrofracturing of the host rocks results in significant decrease of $\mathrm{CO}_{2}$ solubility and $\mathrm{pH}$ increase, which can cause in turn wolframite precipitation (Liu et al., 2017).

\subsection{Overprint of the W-mineralized system by a rare- metal granite}

Wolframite deposition in the Puy-les-Vignes deposit occurred during the main ore stage II at $318 \mathrm{Ma}$ and was followed by precipitation of accessory $\mathrm{W}-\mathrm{Nb}-\mathrm{Ta}$ oxide minerals (wolframoixiolite, $\mathrm{Ta}-\mathrm{Nb}-$ ferberite, and $\mathrm{W}-\mathrm{Nb}-\mathrm{Ta}-$ rutile). Wolframoixiolite is found as infill of dissolution microvugs in wolframite, in quartz-filled veinlets cutting wolframite, and as disseminations overgrown by ferberite-1 within scheelite; all together suggesting that the fluid having precipitated wolframoixiolite was out of equilibrium with wolframite. Ferberite- 1 cuts and replaces wolframite along crystal borders and in dissolution microvugs and locally shows $\mathrm{Ta}-\mathrm{Nb}$-rich primary zoning. Such primary textures are similar to those described for $\mathrm{Nb}$-rich ferberite from the Echassières W deposit in the northern FMC (Aïssa et al., 1987; Harlaux et al., 2018a, b). Nb-Ta-rich rutile is found as disseminations within ferberite- 1 and forms overgrowths on $\mathrm{Fe}-\mathrm{W}$-rutile, the latter being interpreted as coeval with wolframite deposition similarly to the findings of Carocci et al. (2019) in the Panasqueira W deposit (Portugal). Several studies showed that the association of $\mathrm{Ta}-\mathrm{Nb}$-ferberite, $\mathrm{W}-\mathrm{Nb}-\mathrm{Ta}-$ rutile, wolframoixiolite, and columbite-tantalite minerals is a marker of the magmatic-hydrothermal transition in RMGRMP (Breiter et al., 2007, 2017; Alekseev et al., 2011; René and Škoda, 2011; Zhu et al., 2015, 2019; Michaud et al., 2020). The studied sample of RMG exhibits all the mineralogical and geochemical features of a highly fractionated P-rich peraluminous RMG cupola (Cuney et al., 1992; Raimbault et al., 1995; Zhu et al., 2001; Breiter et al., 2005; Linnen and Cuney, 2005) and shows similarities with other Prich peraluminous RMG-RMP from the northern FMC (Aubert, 1969; Mourey, 1985; Cuney et al., 1992; Raimbault et al., 1995; Raimbault, 1998). Additionally, columbitetantalite disseminated in the RMG exhibits an increasing $\mathrm{Ta} /$ $(\mathrm{Ta}+\mathrm{Nb})$ ratio at relatively constant $\mathrm{Mn} /(\mathrm{Mn}+\mathrm{Fe})$ ratio from core to rim, as also documented in other RMG-RMP from the northern FMC (Wang et al., 1992; Belkasmi and Cuney, 1998; Belkasmi et al., 2000). The progressive increase in the $\mathrm{Ta} /(\mathrm{Ta}+\mathrm{Nb})$ ratio may reflect either a magmatic fractionation trend due to the higher solubility of tantalite relative to columbite in peraluminous melts, or the effect of fluid-mineral interaction during a late hydrothermal remobilization (Linnen and Cuney, 2005; Van Lichtervelde etal., 2007; Breiteretal., 2007; Zhu etal.,2015; Wu et al., 2018).

Experimental works and fluid-melt-crystal partitioning calculations show that $\mathrm{W}$ partitions readily into magmatic fluid relative to the silicate melt in peraluminous granites (Zajacz et al., 2008; Hulsbosch et al., 2016; Schmidt et al., 2020). In contrast, $\mathrm{Nb}$ and $\mathrm{Ta}$ preferentially partition into the silicate melt (Linnen and Cuney, 2005; Borodulin et al., 2009). However, the solubility of $\mathrm{Nb}$ and $\mathrm{Ta}$ is strongly enhanced in F-rich hydrothermal fluids as shown by experimental studies (Zaraisky et al., 2010; Timofeev et al., 2015, 2017). As a consequence, F-rich magmatic fluids released during crystallization and water saturation of a RMG melt can transport significant amounts of $\mathrm{W}, \mathrm{Nb}$, and $\mathrm{Ta}$. This is confirmed by elevated concentrations of $\mathrm{W}(>100 \mathrm{sppm})$ and $\mathrm{Nb}-\mathrm{Ta}$ $(>1000 \mathrm{sppm})$ measured in individual primary fluid inclusions ( 400 to $>600{ }^{\circ} \mathrm{C}, 18$ to $48 \mathrm{wt} . \% \mathrm{NaCl}$ eq) from the Beauvoir RMG, for which a F content of about 1.6-2.0 wt.\% was estimated in the magmatic fluid (Harlaux et al., 2017). The nearby La Bosse quartz-ferberite stockwork was strongly overprinted by the magmatic fluids issued from the Beauvoir granite, resulting in crystallization of topaz, partial dissolution of quartz, and precipitation of accessory Li-micas and W-Nb-Ta oxides (Aïssa et al., 1987; Cuney et al., 1992). Specifically, Ta-rich ferberite, wolframoixiolite, and columbite-tantalite minerals were described in dissolution microvugs within ferberite and were interpreted to be precipitated by the magmatic fluids released from the Beauvoir granitic melt (Cuney et al., 1992; Harlaux et al., 2017). Consequently, we propose that the $\mathrm{W}-\mathrm{Nb}-\mathrm{Ta}$ oxide assemblages observed in the quartz-wolframite veins from the Puy-les-Vignes deposit were precipitated from a magmatic-hydrothermal fluid issued from a concealed P-rich peraluminous RMG that overprinted the Wmineralized system (Fig. 22).

\section{Conclusions}

We showed that the formation of the Puy-les-Vignes W breccia pipe results from a multistage development during 25 million years related to four major episodes in the late Carboniferous. The first episode corresponds to the emplacement of an unexposed peraluminous granite at ca. $324 \mathrm{Ma}$, which generated microgranite dykes exposed at the presentday surface. The second episode resulted in the formation of the quartz-supported breccia pipe and wolframite mineralization at ca. $318 \mathrm{Ma}$ at a paleodepth of ca. $7 \mathrm{~km}$. The mineralizing fluids have a $\mathrm{H}_{2} \mathrm{O}-\mathrm{NaCl}-\mathrm{CO}_{2}-\mathrm{CH}_{4}-\mathrm{N}_{2}$ composition, a moderate-salinity $(<9 \mathrm{wt} . \% \mathrm{NaCleq})$ and were trapped at high-temperatures $\left(>400^{\circ} \mathrm{C}\right)$ during lithostatic to hydrostatic pressure variations caused by hydrofracturing of the host rocks. We interpret wolframite precipitation as the result of a W-rich intermediate-density magmatic fluid that exsolved from an evolved leucogranite and interacted with volatile-rich metasedimentary country rocks and/or possibly mixed with low-salinity metamorphic fluids of deep origin. The third episode corresponds to a magmatic-hydrothermal $\mathrm{Nb}-\mathrm{Ta}$ mineralization interpreted to be related to the intrusion at ca. $311 \mathrm{Ma}$ of a P-rich peraluminous RMG overprinting the W-mineralized system. The last episode corresponds to a disseminated $\mathrm{Bi} \pm \mathrm{Au}-\mathrm{Ag}$ mineralization emplaced at ca. $300 \mathrm{Ma}$, which shares mineralogical features with late Carboniferous orogenic gold deposits in the FMC.

\section{Supplementary Material}

Supplementary Table 1. Operating conditions for the LAICP-MS equipment used for U-Pb dating of rutile.

Supplementary Table 2. Major element compositions of hydrothermal rutile from Puy-les-Vignes determined by EMPA. Supplementary Table 3. Trace element compositions of hydrothermal rutile from Puy-les-Vignes measured by LA-ICP-MS. 
Supplementary Table 4. Chemical compositions of cassiterite from Puy-les-Vignes determined by EMPA.

Supplementary Table 5. Chemical compositions of wolframoixiolite from Puy-les-Vignes determined by EMPA.

Supplementary Table 6. Chemical compositions of columbite-tantalite from Puy-les-Vignes determined by EMPA.

Supplementary Table 7. Mass balance calculation of the volume of fluids required for the formation of the Puy-lesVignes breccia pipe.

The Supplementary Material is available at http://www.bsgf.fr/ 10.1051/bsgf/2021023/olm.

Acknowledgements. This work was supported by the French National Research Agency through the national program "Investissements d'avenir" of the Labex Ressources 21 (ANR10-LABX-21-RESSOURCES21) and the ERAMIN project NewOres (ANR-14-EMIN-0001). The authors greatly thank Dr. Hossein Ahmadzadeh and the Musée Minéralogique de l'École des Mines d'Alès (France) for supplying samples of collection from the Puy-les-Vignes mine. We also thank Drs. Hélène Legros and Patrice Bruneton for their assistance in the field. Technical support by Sandrine Mathieu, Dr. Andrei Lecomte (SEM), Dr. Olivier Rouer (EMPA), Dr. Chantal Peiffert (LA-ICP-MS) and Dr. Marie-Camille Caumon (Raman spectroscopy) is gratefully acknowledged. We acknowledge the GeOHeLiS platform (Univ. Rennes, France) for the LA-ICP-MS U-Th/Pb dating facilities. Drs. Vincent Casanova and Bertrand Rottier are also warmly thanked for their help during the infrared microthermometric analyses of wolframite at the University of Geneva, Switzerland. Finally, we would like to thank an anonymous reviewer and the Guest Editor Dr. Eric Marcoux for their critical comments that helped to improve the original manuscript.

\section{References}

Aïssa M, Marignac C, Weisbrod A. 1987. Le stockwerk à ferbérite d'Echassières : évolution spatiale et temporelle ; cristallochimie des ferbérites. Géologie de la France 2-3: 311-333.

Alekseev VI, Gembitskaya IM, Marin YB. 2011. Wolframoixiolite and niobian ferberite from zinnwaldite granitic rocks of the Chukchi Peninsula. Geology of Ore Deposits 53: 639-648.

Alexandre P. 2007. U-Pb zircon SIMS ages from the French Massif Central and implication for the pre-Variscan tectonic evolution in Western Europe. Comptes Rendus Geoscience 339: 613-621.

Alexandre P, Le Carlier de Veslud C, Cuney M, Ruffet G, Virlogeux D, Cheilletz A. 2002. Datation ${ }^{40} \mathrm{Ar} /{ }^{39} \mathrm{Ar}$ des leucogranites sous couverture du complexe plutonique de Charroux-Civray (Vienne). Comptes Rendus Geoscience 334: 1141-1148.

Alexandrov P, Cheilletz A, Deloule E, Cuney M. 2000. 319 7 Ma crystallization age for the Blond granite (northwest Limousin, French Massif Central) obtained by $\mathrm{U} / \mathrm{Pb}$ ion-probe dating of zircons. Comptes Rendus de l'Académie des Sciences 330: 617-622.

Alexandrov P, Floc'h JP, Cuney M, Cheilletz A. 2001. Datation U-Pb à la microsonde ionique des zircons de l'unité supérieure des gneiss dans le Sud Limousin, Massif Central. Comptes Rendus de l'Académie des Sciences 332: 625-632.

Alikouss S. 1993. Contribution à l'étude des fluides crustaux : approche analytique et expérimentale. Unpublished Ph.D. Thesis, Institut National Polytechnique de Lorraine, France, 255 p.
Anderson ED, Atkinson Jr WW, Marsh T, Iriondo A. 2009. Geology and geochemistry of the Mammoth breccia pipe, Copper Creek mining district, southeastern Arizona: evidence for a magmatichydrothermal origin. Mineralium Deposita 44: 151-170.

Arniaud D, Dupuy C, Dostal J. 1984. Geochemistry of Auriat granite (Massif Central, France). Chemical Geology 45: 263-277.

Aubert G. 1969. Les coupoles granitiques de Montebras et d'Echassières (Massif Central Français) et la genèse de leurs minéralisations en étain, lithium, tungstène et béryllium. Mémoires du BRGM 46: 350.

Audion AS, Labbé JF. 2012. Panorama mondial 2011 du marché du tungstène. Rapport Public BRGM, RP-61341-FR, 108 p.

Baker EM, Andrew AS. 1991. Geologic, fluid inclusion, and stable isotope studies of the gold-bearing breccia pipe at Kidston, Queensland, Australia. Economic Geology 86: 810-830.

Bakker RJ. 1997. Clathrates: Computer programs to calculate fluid inclusion VX properties using clathrate melting temperatures. Computers \& Geosciences 23: 1-18.

Bakker RJ. 1999. Adaptation of the Bowers and Helgeson (1983) equation of state to the $\mathrm{H}_{2} \mathrm{O}-\mathrm{CO}_{2}-\mathrm{CH}_{4}-\mathrm{N}_{2}-\mathrm{NaCl}$ system. Chemical Geology 154: 225-236.

Bakker RJ. 2003. Package FLUIDS 1. Computer programs for analysis of fluid inclusion data and for modelling bulk fluid properties. Chemical Geology 194: 3-23.

Bakker RJ, Schilli SE. 2016. Formation conditions of leucogranite dykes and aplite-pegmatite dykes in the eastern Mt. Capanne plutonic complex (Elba, Italy): fluid inclusion studies in quartz, tourmaline, andalusite and plagioclase. Mineralogy and Petrology 110: 43-63.

Ballouard C, Poujol M, Boulvais P, Branquet Y, Tartèse R, Vigneresse JL. 2016. Nb-Ta fractionation in peraluminous granites: A marker of the magmatic-hydrothermal transition. Geology 44: 231-234.

Bea F. 2010. Crystallization dynamics of granite magma chambers in the absence of regional stress: multiphysics modeling with natural examples. Journal of Petrology 51: 1541-1569.

Bebout GE, Cooper DC, Bradley AD, Sadofsky SJ. 1999. Nitrogenisotope record of fluid-rock interactions in the Skiddaw aureole and granite, English Lake District. American Mineralogist 84: 1495 1505.

Belkasmi M, Cuney M. 1998. Les columbo-tantalites zonées du granite de Montebras (Massif Central Français). Implications pétrogénétiques. Comptes Rendus de l'Académie des Sciences 326: 459-465.

Belkasmi M, Cuney M, Pollard PJ, Bastoul A. 2000. Chemistry of the $\mathrm{Ta}-\mathrm{Nb}-\mathrm{Sn}-\mathrm{W}$ oxide minerals from the Yichun rare metal granite (SE China): genetic implications and comparison with Moroccan and French Hercynian examples. Mineralogical Magazine 64: 507-523.

Berger J, Féménias O, Ohnenstetter D, Bruguier O, Plissart G, Mercier JCC, et al. 2010. New occurrence of UHP eclogites in Limousin (French Massif Central): age, tectonic setting and fluidrock interactions. Lithos 118: 365-382.

Berthier F, Duthou JL, Roques M. 1979. Datation géochronologique $\mathrm{Rb} / \mathrm{Sr}$ sur roches totales du granite de Guéret (Massif Central). Age fini-Dévonien de mise en place de l'un de ses faciès types. Bulletin du BRGM 1: 31-42.

Bertrand JM, Leterrier J, Cuney M, Brouand M, Stussi JM, Delaperriere E, et al. 2001. Géochronologie U-Pb sur zircons de granitoïdes du Confolentais, du massif de Charroux-Civray (Poitou) et de Vendée. Géologie de la France 1-2: 167-180.

Bertrand G, Charles N, Melleton J, Tourlière B, Cassard D, Dupuy JJ, et al. 2015. Réévaluation du potentiel français en ressources minérales : retraitement des données géochimiques de l'Inventaire 
et établissement de fiches de cibles minières. Synthèse des travaux réalisés de 2013 à 2015. Rapport BRGM, RP-65165-FR, 434 p.

Blundy J, Cashman KV, Rust A, Witham F. 2010. A case for $\mathrm{CO}_{2}$-rich arc magmas. Earth and Planetary Science Letters 290: 289-301.

Bobos I, Noronha F, Mateus A. 2018. Fe-, Fe, Mn- and Fe, $\mathrm{Mg}_{-}$ chlorite: a genetic linkage to $\mathrm{W},(\mathrm{Cu}, \mathrm{Mo})$ mineralization in the magmatic-hydrothermal system at Borralha, northern Portugal. Mineralogical Magazine 82: 259-279.

Bodnar RJ, Binns PR, Hall DL. 1989. Synthetic fluid inclusions. VI. Quantitative evaluation of the decrepitation behavior of fluid inclusion in quartz at one atmosphere confining pressure. Journal of Metamorphic Geology 7: 229-242.

Boiron MC, Cathelineau M, Banks DA, Fourcade S, Vallance J. 2003. Mixing of metamorphic and surficial fluids during the uplift of the Hercynian upper crust: consequences for gold deposition. Chemical Geology 194: 119-141.

Boiron MC, Cathelineau M, Ruggieri G, Jeanningros A, Gianelli G, Banks D. 2007. Active contact metamorphism and $\mathrm{CO}_{2}-\mathrm{CH}_{4}$ fluid production in the Larderello geothermal field (Italy) at depths between 2.3 and $4 \mathrm{~km}$. Chemical Geology 237: 303-328.

Borodulin GP, Chevychelov VY, Zaraysky GP. 2009. Experimental study of partitioning of tantalum, niobium, manganese, and fluorine between aqueous fluoride fluid and granitic and alkaline melts. Doklady Earth Sciences 427: 868-873.

Bouchot V, Ledru P, Lerouge C, Lescuyer JL, Milesi JP. 2005. 5: Late Variscan mineralizing systems related to orogenic processes: The French Massif Central. Ore Geology Reviews 27: 169-197.

Boulliung J, Füri E, Dalou C, Tissandier L, Zimmermann L, Marrocchi Y. 2020. Oxygen fugacity and melt composition controls on nitrogen solubility in silicate melts. Geochimica et Cosmochimica Acta 284: 120-133.

Boutin A, de Saint Blanquat M, Poujol M, Boulvais P, de Parseval P, Rouleau C, et al. 2016. Succession of Permian and Mesozoic metasomatic events in the eastern Pyrenees with emphasis on the Trimouns talc-chlorite deposit. International Journal of Earth Sciences 105: 747-770.

Breiter K, Müller A, Leichmann J, Gabašová A. 2005. Textural and chemical evolution of a fractionated granitic system: the Podlesí stock, Czech Republic. Lithos 80: 323-345.

Breiter K, Škoda R, Uher P. 2007. Nb-Ta-Ti-W-Sn-oxide minerals as indicators of a peraluminous P-and F-rich granitic system evolution: Podlesí, Czech Republic. Mineralogy and Petrology 91: 225-248.

Breiter K, Korbelová Z, Chládek Š, Uher P, Knesl I, Rambousek P, et al. 2017. Diversity of Ti-Sn-W-Nb-Ta oxide minerals in the classic granite-related magmatic-hydrothermal Cínovec/Zinnwald $\mathrm{Sn}-\mathrm{W}-\mathrm{Li}$ deposit (Czech Republic). European Journal of Mineralogy 29: 727-738.

Bril H, Beaufort D. 1989. Hydrothermal alteration and fluid circulation related to $\mathrm{W}, \mathrm{Au}$, and $\mathrm{Sb}$ vein mineralization, Haut Allier, Massif Central, France. Economic Geology 84: 2237-2251.

Burke EA. 2001. Raman microspectrometry of fluid inclusions. Lithos 55: 139-158.

Burnham CW. 1985. Energy release in subvolcanic environments; implications for breccia formation. Economic Geology 80: 15151522.

Burnol L. 1974. Géochimie du béryllium et types de concentrations dans les leucogranites du Massif Central Français. Mémoires $d u$ BRGM 85: 168 .

Cabral AR, Rios FJ, de Oliveira LAR, de Abreu FR, Lehmann B, Zack T, et al. 2015. Fluid-inclusion microthermometry and the Zrin-rutile thermometer for hydrothermal rutile. International Journal of Earth Sciences 104: 513-519.
Carignan J, Hild P, Mevelle G, Morel J, Yeghicheyan D. 2001. Routine analyses of trace elements in geological samples using flow injection and low pressure on-line liquid chromatography coupled to ICP-MS: a study of geochemical reference materials BR, DR-N, UB-N, AN-G and GH. Geostandards Newsletter 25: 187-198.

Carocci E, Marignac C, Cathelineau M, Truche L, Lecomte A, Pinto F. 2019. Rutile from Panasqueira (Central Portugal): an excellent pathfinder for wolframite deposition. Minerals 9: 9.

Carocci E, Marignac C, Cathelineau M, Truche L, Poujol M, Boiron MC, et al. 2021. Incipient Wolframite Deposition at Panasqueira (Portugal): W Rutile and Tourmaline Compositions as Proxies for the Early Fluid Composition. Economic Geology 116: 123-146.

Cartannaz C. 2005. Magmatismes et déformations polyphasés: exemple des massifs de Guéret et de Millevaches (Massif Central Français). Origine des magmas et contexte de mise en place. Unpublished Ph.D. Thesis, Université de Franche-Comté, France, $317 \mathrm{p}$.

Cartannaz C, Rolin P, Cocherie A, Marquer D, Legendre O, Fanning $\mathrm{CM}$, et al. 2007. Characterization of wrench tectonics from dating of syn-to post-magmatism in the north-western French Massif Central. International Journal of Earth Sciences 96: 271-287.

Casanova V, Kouzmanov K, Audétat A, Wälle M, Ubrig N, Ortelli M, et al. 2018. Fluid inclusion studies in opaque ore minerals: II. A comparative study of syngenetic synthetic fluid inclusions hosted in quartz and opaque minerals. Economic Geology 113: 1861-1883.

Černý P, Blevin PL, Cuney M, London D. 2005. Granite-related ore deposits. Economic Geology $100^{\text {th }}$ Anniversary Vol. 337-370.

Chalier M, Virlogeux D, Duthou JL. 1994. Les lamprophyres du district aurifère de Saint Yrieix (Limousin, Massif Central français). Age $\mathrm{Rb} / \mathrm{Sr}$ Autunien et relations chronologiques avec le dépôt de l'or. Comptes Rendus de l'Académie des Sciences 319: 1511-1518.

Charoy B, Noronha F. 1996. Multistage growth of a rare-element, volatile-rich microgranite at Argemela (Portugal). Journal of Petrology 37: 73-94.

Chauris L, Marcoux E. 1994. Metallogeny of the Armorican Massif. In: Chantraine J, Rolet J, Santallier DS, Piquet A, Keppie JD, eds. Pre-Mesozoic Geology in France and Related Areas. Berlin Heidelberg: Springer, pp. 243-264.

Cheilletz A, Archibald DA, Cuney M, Charoy B. 1992. Ages ${ }^{40} \mathrm{Ar}{ }^{39} \mathrm{Ar}$ du leucogranite à topaze-lépidolite de Beauvoir et des pegmatites sodolithiques de Chédeville (Nord du Massif Central, France). Signification pétrologique et géodynamique. Comptes Rendus de l'Académie des Sciences 315: 329-336.

Chelle-Michou C, Laurent O, Moyen JF, Block S, Paquette JL, Couzinié S, et al. 2017. Pre-Cadomian to late- Variscan odyssey of the eastern Massif Central, France: formation of the West European crust in a nutshell. Gondwana Research 46: 170-190.

Chen YJ, Pirajno F, Li N, Guo DS, Lai Y. 2009. Isotope systematics and fluid inclusion studies of the Qiyugou breccia pipe-hosted gold deposit, Qinling Orogen, Henan province, China: implications for ore genesis. Ore Geology Reviews 35: 245-261.

Chenevoy M, Constans JE, Recoing M. 1984. Carte géologique à $1 / 50000$ Saint-Léonard-de-Noblat et notice explicative. Éditions BRGM, $44 \mathrm{p}$.

Chicharro E, Boiron MC, López-García JÁ, Barfod DN, Villaseca C. 2016. Origin, ore forming fluid evolution and timing of the Logrosán Sn-(W) ore deposits (Central Iberian Zone, Spain). Ore Geology Reviews 72: 896-913.

Connolly JA. 1997. Mid-crustal focused fluid movement: thermal consequences and silica transport. In: Jamtveit B, Yardley BWD, eds. Fluid Flow and Transport in Rocks: Mechanisms and Effects. Dordrecht: Springer, pp. 235-250. 
Couzinié S. 2017. Evolution of the continental crust and significance of the zircon record, a case study from the French Massif Central. Unpublished Ph.D. Thesis, Université de St-Etienne, France, 436 p.

Couzinié S, Laurent O, Poujol M, Mintrone M, Chelle-Michou C, Moyen JF, et al. 2017. Cadomian S-type granites as basement rocks of the Variscan belt (Massif Central, France): Implications for the crustal evolution of the north Gondwana margin. Lithos 286: $16-34$.

Couzinié S, Laurent O, Chelle-Michou C, Bouilhol P, Paquette JL, Gannoun AM, et al. 2019. Detrital zircon U-Pb-Hf systematics of Ediacaran metasediments from the French Massif Central: Consequences for the crustal evolution of the north Gondwana margin. Precambrian Research 324: 269-284.

Cuney M, Friedrich M, Blumenfeld P, Bourguignon A, Boiron MC, Vigneresse JL, Poty B. 1990. Metallogenesis in the French part of the Variscan orogen. Part I: U preconcentrations in pre-Variscan and Variscan formations - A comparison with Sn, W and Au. Tectonophysics 177: 39-57.

Cuney M, Marignac C, Weisbrod A. 1992. The Beauvoir topazlepidolite albite granite (Massif Central, France): the disseminated magmatic $\mathrm{Sn}-\mathrm{Li}-\mathrm{Ta}-\mathrm{Nb}-\mathrm{Be}$ mineralization. Economic Geology 87: $1766-1794$.

Cuney M, Stussi JM, Brouand M, Dautel D, Michard A, Gros Y, et al. 1993. Âge U/Pb du granite de Largeasse, un épisode magmatique peralumineux viséen dans le haut Bocage vendéen. Comptes Rendus de l'Académie des Sciences 316: 1383-1390.

Cuney M, Alexandrov P, Le Carlier de Veslud C, Cheilletz A, Raimbault $\mathrm{L}$, Ruffet $\mathrm{G}$, et al. 2002. The timing of $\mathrm{W}-\mathrm{Sn}$ rare metals mineral deposit formation in the Western Variscan chain in their orogenic setting: the case of the Limousin area (Massif Central, France). In: Blundell DJ, Neubauer F, Von Quadt A, eds. The Timing and Location of Major Ore Deposits in an Evolving Orogen. Geological Society of London Special Publication 204: 213-228.

Debon F, Le Fort P. 1983. A chemical-mineralogical classification of common plutonic rocks and associations. Transactions of the Royal Society of Edinburgh 73: 135-149.

Deino AL. 2013. Berkeley Geochronology Center, Mass Spec, ${ }^{40} \mathrm{Ar} /{ }^{39} \mathrm{Ar}$ data measurement and reduction software. http://www. bgc.org/facilities/other_facil.html.

Demirel S, Göncüoğlu MC, Topuz G, Isik V. 2009. Geology and chemical variations in tourmaline from the quartz-tourmaline breccias within the Kerkenez granite-monzonite massif, Central Anatolian Crystalline Complex, Turkey. The Canadian Mineralogist 47: 787-799.

Dewaele S, De Clercq F, Hulsbosch N, Piessens K, Boyce A, Burgess R, Muchez P. 2016. Genesis of the vein-type tungsten mineralization at Nyakabingo (Rwanda) in the Karagwe-Ankole belt, Central Africa. Mineralium Deposita 51: 283-307.

Do Couto D, Faure M, Augier R, Cocherie A, Rossi P, Li XH, et al. 2016. Monazite U-Th-Pb EPMA and zircon U-Pb SIMS chronological constraints on the tectonic, metamorphic, and thermal events in the inner part of the Variscan orogen, example from the Sioule series, French Massif Central. International Journal of Earth Sciences 105: 557-579.

Downes H, Duthou JL. 1988. Isotopic and trace-element arguments for the lower-crustal origin of Hercynian granitoids and preHercynian orthogneisses, Massif Central (France). Chemical Geology 68: 291-308.

Downes H, Shaw A, Williamson BJ, Thirlwall MF. 1997. Sr, Nd and $\mathrm{Pb}$ isotopic evidence for the lower crustal origin of Hercynian granodiorites and monzogranites, Massif Central, France. Chemical Geology 136: 99-122.
Driesner T, Heinrich CA. 2007. The system $\mathrm{H}_{2} \mathrm{O}-\mathrm{NaCl}$. Part I: Correlation formulae for phase relations in temperature-pressurecomposition space from 0 to $1000^{\circ} \mathrm{C}, 0$ to $5000 \mathrm{bar}$, and 0 to $1 \mathrm{XNaCl}$. Geochimica et Cosmochimica Acta 71: 4880-4901.

Duan Z, Møller N, Weare JH. 1996. A general equation of state for supercritical fluid mixtures and molecular dynamics simulation of mixture PVTX properties. Geochimica et Cosmochimica Acta 60: 1209-1216.

Dubessy J, Poty B, Ramboz C. 1989. Advances in C-O-H-N-S fluid geochemistry based on micro-Raman spectrometric analysis of fluid inclusions. European Journal of Mineralogy 1: 517-534.

Dubessy J, Derome D, Sausse J. 2003. Numerical modelling of fluid mixings in the $\mathrm{H}_{2} \mathrm{O}-\mathrm{NaCl}$ system application to the North Caramal U prospect (Australia). Chemical Geology 194: 25-39.

Dudek B. 1978. Cartographie et typologie des schistes cristallins et des granites de la région de Bujaleuf (Haut Limousin, Massif Central Français). Unpublished Ph.D. Thesis, Université Claude Bernard Lyon, France, 110 p.

Duthou JL. 1978. Les granitoïdes du Haut Limousin (Massif central français), chronologie $\mathrm{Rb} / \mathrm{Sr}$ de leur mise en place; le thermométamorphisme carbonifère. Bulletin de la Société Géologique de France 20: 229-235.

Duthou JL, Cantagrel JM, Didier J, Vialette Y. 1984. Palaeozoic granitoids from the French Massif Central: age and origin studied by ${ }^{87} \mathrm{Rb}-{ }^{87} \mathrm{Sr}$ system. Physics of the Earth and Planetary Interiors 35: 131-144.

El Korh A, Boiron MC, Cathelineau M, Deloule E, Luais B. 2020. Tracing metallic pre-concentrations in the Limousin ophiolitederived rocks and Variscan granites (French Massif Central). Lithos 356: 105345.

Faure M, Lardeaux JM, Ledru P. 2009a. A review of the pre-Permian geology of the Variscan French Massif Central. Comptes Rendus Geoscience 341: 202-213.

Faure M, Mezeme EB, Cocherie A, Melleton J, Rossi P. 2009b. The South Millevaches Middle Carboniferous crustal melting and its place in the French Variscan belt. Bulletin de la Société Géologique de France 180: 473-481.

Fricker MB. 2012. Design of ablation cells for LA-ICP-MS: from modeling to high spatial resolution analysis applications. Unpublished Ph.D. Thesis, ETH Zürich, Switzerland, 173 p.

Fuertes-Fuente M, Martin-Izard A, Boiron MC, Mangas J. 2000. Fluid evolution of rare-element and muscovite granitic pegmatites from central Galicia, NW Spain. Mineralium Deposita 35: 332-345.

Gardien V, Vanderhaeghe O, Arnaud N, Cocherie A, Grange M, Lécuyer C. 2011. Thermal maturation and exhumation of a middle orogenic crust in the Livradois area (French Massif Central). Bulletin de la Société Géologique de France 182: 5-24.

Gauthier JC. 1973. Evolution granitique, développement des granites à deux micas et géochimie des alcalins dans la Marche Orientale (Massif Central Français). I-L'évolution granitique. Sciences de la Terre (Nancy) 18: 315-352

Gebauer H, Bernard-Griffiths J, Gnünenfelder M. 1981. U/Pb zircon and monazite dating of mafic-ultramafic complex and its country rocks. Example: Sauviat-sur-Vige, French Massif Central. Contributions to Mineralogy and Petrology 76: 292-300.

Gébelin A. 2004. Déformation et mise en place des granites (360-300 Ma) dans un segment de la Chaîne Varisque (Plateau de Millevaches, Massif Central). Unpublished Ph.D. Thesis, Université de Montpellier, France, 235 p.

Gébelin A, Brunel M, Monié P, Faure M, Arnaud N. 2007. Transpressional tectonics and Carboniferous magmatism in the Limousin, Massif Central, France: Structural and ${ }^{40} \mathrm{Ar} /{ }^{39} \mathrm{Ar}$ investigations. Tectonics 26. 
Gébelin A, Roger F, Brunel M. 2009. Syntectonic crustal melting and high-grade metamorphism in a transpressional regime, Variscan Massif Central, France. Tectonophysics 477: 229-243.

Gibert F, Moine B, Schott J, Dandurand JL. 1992. Modeling of the transport and deposition of tungsten in the scheelite-bearing calcsilicate gneisses of the Montagne Noire, France. Contributions to Mineralogy and Petrology 112: 371-384.

Gonçalves A, Lima L, Mota A, Ramos V, Barros J, Noronha F. 2017. The Santa Helena Breccia Pipe (Borralha-North Portugal). A new type of $\mathrm{W}$ ore deposit in the Iberian Tin-Tungsten Metallogenic Province. Comunicações Geológicas 104: 1-6.

Guedes A, Noronha F, Boiron MC, Banks DA. 2002. Evolution of fluids associated with metasedimentary sequences from Chaves (North Portugal). Chemical Geology 190: 273-289.

Guyonnaud G, Burnol L, Recoing M. 1977. Carte géologique à 1/50 000 Limoges et notice explicative. Éditions BRGM, 25 p.

Hall DL, Bodnar RJ. 1990. Methane in fluid inclusions from granulites: A product of hydrogen diffusion? Geochimica et Cosmochimica Acta 54: 641-651.

Halls C. 1994. Energy and mechanism in the magmatic-hydrothermal evolution of the Cornubian batholith: a review. In: Seltmann R, Kämpf H, Möller P, eds. Metallogeny of Collisional Orogens. Prague: Czech Geological Survey, pp. 274-294.

Harlaux M. 2016. Tungsten and rare-metal (Nb, Ta, Sn) hydrothermal metallogenic systems in the late-Variscan orogenic context: Example of the French Massif Central. Unpublished Ph.D. Thesis, Université de Lorraine, Nancy, France, 576 p.

Harlaux M, Marignac C, Cuney M, Mercadier J. 2015a. The Puy-lesVignes breccia pipe (Massif Central, France): a unique occurrence of polymetallic $\mathrm{W}-\mathrm{Nb} \pm \mathrm{Ta}-\mathrm{HREE}-\mathrm{Bi}-\mathrm{Cu}-\mathrm{As} \pm \mathrm{Au}-\mathrm{Ag}$ mineralization in the Variscan belt. Proceedings of the 13th Biennial SGA Meeting, 24-27 August 2015, Nancy 2: 749-752.

Harlaux M, Marignac C, Cuney M, Mercadier J, Magott R, Mouthier B. 2015b. Nb-Ti-Y-HREE-W-U oxide minerals with uncommon compositions associated with the tungsten mineralization in the Puy-les-Vignes deposit (Massif Central, France): evidence for rare metal mobilization by late hydrothermal fluids with a peralkaline signature. The Canadian Mineralogist 53: 653-672.

Harlaux M, Mercadier J, Bonzi WME, Kremer V, Marignac C, Cuney M. 2017. Geochemical signature of magmatic-hydrothermal fluids exsolved from the Beauvoir rare-metal granite (Massif Central, France): insights from LA-ICPMS analysis of primary fluid inclusions. Geofluids 2017: 1-25.

Harlaux M, Romer RL, Mercadier J, Morlot C, Marignac C, Cuney M. 2018a. 40 Ma of hydrothermal W mineralization during the Variscan orogenic evolution of the French Massif Central revealed by U-Pb dating of wolframite. Mineralium Deposita 53: 21-51.

Harlaux M, Mercadier J, Marignac C, Peiffert C, Cloquet C, Cuney M. 2018b. Tracing metal sources in peribatholitic hydrothermal W deposits based on the chemical composition of wolframite: The example of the Variscan French Massif Central. Chemical Geology 479: 58-85.

Harlaux M, Mercadier J, Marignac C, Villeneuve J, Mouthier B, Cuney M. 2019. Origin of the atypical Puy-les-Vignes W breccia pipe (Massif Central, France) constrained by trace element and boron isotopic composition of tourmaline. Ore Geology Reviews 114: 103132.

Harrison TM, Célérier J, Aikman AB, Hermann J, Heizler MT. 2009. Diffusion of ${ }^{40} \mathrm{Ar}$ in muscovite. Geochimica et Cosmochimica Acta 73:1039-1051.

Heinrich CA. 1990. The chemistry of hydrothermal tin(-tungsten) ore deposition. Economic Geology 85: 457-481.

Holliger P, Cuney M, Friedrich M, Turpin L. 1986. Age Carbonifère de l'unité de Brâme du complexe granitique peralumineux de Saint Sylvestre (N.O. Massif Central) défini par les données isotopiques
$\mathrm{U}-\mathrm{Pb}$ sur zircon et monazite. Comptes Rendus de l'Académie des Sciences 303: 1309-1314.

Horstwood MSA, Košler J, Gehrels G, Jackson SE, McLean NM, Paton C, et al. 2016. Community-Derived Standards for LA-ICPMS U-(Th-) Pb Geochronology-Uncertainty Propagation, Age Interpretation and Data Reporting. Geostandards and Geoanalytical Research 40: 311-332.

Huerta AD, Royden LH, Hodges KV. 1998. The thermal structure of collisional orogens as a response to accretion, erosion, and radiogenic heating. Journal of Geophysical Research: Solid Earth 103: 15287-15302.

Huff TA, Nabelek PI. 2007. Production of carbonic fluids during metamorphism of graphitic pelites in a collisional orogen - an assessment from fluid inclusions. Geochimica et Cosmochimica Acta 71: 4997-5015.

Huizenga JM. 2001. Thermodynamic modelling of C-O-H fluids. Lithos 55: 101-114.

Hulsbosch N, Boiron MC, Dewaele S, Muchez P. 2016. Fluid fractionation of tungsten during granite-pegmatite differentiation and the metal source of peribatholitic W quartz veins: Evidence from the Karagwe-Ankole Belt (Rwanda). Geochimica et Cosmochimica Acta 175: 299-318.

Jébrak M. 1997. Hydrothermal breccias in vein-type ore deposits: a review of mechanisms, morphology and size distribution. Ore Geology Reviews 12: 111-134.

Jochum KP, Weis U, Stoll B, Kuzmin D, Yang Q, Raczek I, et al. 2011. Determination of reference values for NIST SRM 610-617 glasses following ISO guidelines. Geostandards and Geoanalytical Research 35: 397-429.

Joly A, Chen Y, Faure M, Martelet G. 2007. A multidisciplinary study of a syntectonic pluton close to a major lithospheric-scale fault-Relationships between the Montmarault granitic massif and the Sillon Houiller Fault in the Variscan French Massif Central: 1. Geochronology, mineral fabrics, and tectonic implications. Journal of Geophysical Research: Solid Earth 112.

Kouzmanov K, Pokrovski GS. 2012. Hydrothermal controls on metal distribution in porphyry $\mathrm{Cu}(-\mathrm{Mo}-\mathrm{Au})$ systems. Special Publication of the Society of Economic Geologists 16: 573-618.

Kuiper KF, Deino A, Hilgen FJ, Krijgsman W, Renne R, Wijbrans JR. 2008. Synchronizing Rock Clocks of Earth History. Science 320: 500-504.

Lafon JM, Respaut JP. 1988. Géochronologie U-Pb et leucogranites varisques : cas des massifs de Grandrieu (Lozère) et de la Porcherie (Limousin), Massif Central Français. Bulletin de Minéralogie 111: 225-237.

Lamy-Chappuis B, Heinrich CA, Driesner T, Weis P. 2020. Mechanisms and patterns of magmatic fluid transport in cooling hydrous intrusions. Earth and Planetary Science Letters 535: 116111.

Lardeaux JM, Schulmann K, Faure M, Janoušek V, Lexa O, Skrzypek E, et al. 2014. The Moldanubian Zone in the French Massif Central, Vosges/Schwarzwald and Bohemian Massif revisited: differences and similarities. Geological Society of London Special Publications 405: 7-44.

Laurent O, Couzinié S, Zeh A, Vanderhaeghe O, Moyen JF, Villaros A, et al. 2017. Protracted, coeval crust and mantle melting during Variscan late-orogenic evolution: $\mathrm{U}-\mathrm{Pb}$ dating in the eastern French Massif Central. International Journal of Earth Sciences 106: 421-451.

Le Bas MJ, Le Maitre RW, Streckeisen A, Zanettin B. 1986. A chemical classification of volcanic rocks based on the total alkalisilica diagram. Journal of Petrology 27: 745-750.

Le Carlier de Veslud C, Alexandre P, Ruffet G, Cuney M, Cheilletz A. 2013. A two-stage exhumation in Western French Massif Central: 
New geochronological evidences of syn-collisional extension. Lithos 175: 1-15.

Lecumberri-Sanchez P, Vieira R, Heinrich CA, Pinto F, Wälle M. 2017. Fluid-rock interaction is decisive for the formation of tungsten deposits. Geology 45: 579-582.

Leger JM, Wang X, Lameyre J. 1990. Les leucogranites de SaintGoussaud en Limousin: Pétrographie, éléments majeurs et traces dans le sondage de Villechabrolle (Projet Energeroc). Bulletin de la Société Géologique de France 6: 515-524.

Legros H, Richard A, Tarantola A, Kouzmanov K, Mercadier J, Vennemann T, et al. 2019. Multiple fluids involved in graniterelated W-Sn deposits from the world-class Jiangxi province (China). Chemical Geology 508: 92-115.

Legros H, Harlaux M, Mercadier J, Romer RL, Poujol M, Camacho A, et al. 2020. The world-class Nanling metallogenic belt (Jiangxi, China): W and Sn deposition at $160 \mathrm{Ma}$ followed by $30 \mathrm{my}$ of hydrothermal metal redistribution. Ore Geology Reviews 117: 103302.

Lerouge C, Bouchot V, Guerrot C. 2000. Fluids and the W ( \pm As, Au) ore deposits of the Enguialès-Leucamp District, La Châtaigneraie, French Massif Central. Journal of Geochemical Exploration 69: 343-347.

Leroy J, Sonet J. 1976. Contribution à l'étude géochronologique des filons de lamprophyres recoupant le granite à deux micas de SaintSylvestre (Limousin, Massif Central Français). Comptes Rendus de l'Académie des Sciences 283: 1477-1480.

Linnen RL, Cuney M. 2005. Granite-related rare-element deposits and experimental constraints on $\mathrm{Ta}-\mathrm{Nb}-\mathrm{W}-\mathrm{Sn}-\mathrm{Zr}-\mathrm{Hf}$ mineralization. In: Linnen RL, Samson IM, eds. Rare-Element Geochemistry and Mineral Deposits. Geological Association of Canada, Short Course Notes 17: 45-68.

Liu X, Xing H, Zhang D. 2017. Influences of hydraulic fracturing on fluid flow and mineralization at the vein-type tungsten deposits in southern China. Geofluids 2017: 1-11.

Longerich HP, Jackson SE, Günther D. 1996. Laser ablation inductively coupled plasma mass spectrometric transient signal data acquisition and analyte concentration calculation. Journal of Analytical Atomic Spectrometry 11: 899-904.

Lotout C, Pitra P, Poujol M, Van Den Driessche J. 2017. Ordovician magmatism in the Lévézou massif (French Massif Central): tectonic and geodynamic implications. International Journal of Earth Sciences 106: 501-515.

Lotout C, Pitra P, Poujol M, Anczkiewicz R, Van Den Driessche J. 2018. Timing and duration of Variscan high-pressure metamorphism in the French Massif Central: A multimethod geochronological study from the Najac Massif. Lithos 308: 381-394.

Lowenstern JB. 2001. Carbon dioxide in magmas and implications for hydrothermal systems. Mineralium Deposita 36: 490-502.

Ludwig KR. 2008. ISOPLOT Version 3.75: A geochronological toolkit for Microsoft Excel. Berkeley Geochronology Center Special Publication 5: 75.

Luvizotto GL, Zack T, Meyer HP, Ludwig T, Triebold S, Kronz A, et al. 2009. Rutile crystals as potential trace element and isotope mineral standards for microanalysis. Chemical Geology 261: 346-369.

Marignac C, Cuney M. 1999. Ore deposits of the French Massif Central: insight into the metallogenesis of the Variscan collision belt. Mineralium Deposita 34: 472-504.

McDonough WF, Sun SS. 1995. The composition of the Earth. Chemical Geology 120: 223-253.

Melleton J, Cocherie A, Faure M, Rossi P. 2010. Precambrian protoliths and Early Paleozoic magmatism in the French Massif Central: U-Pb data and the North Gondwana connection in the west European Variscan belt. Gondwana Research 17: 13-25.
Melleton J, Gloaguen E, Frei D. 2015. Rare-elements (Li-Be-Ta-Sn$\mathrm{Nb})$ magmatism in the European Variscan belt, a review. Proceedings of the 13th Biennial SGA Meeting, Nancy 2: 24-27.

Melleton J, Gloaguen E, Tourlière B, Martelet G. 2017. Promotion des districts miniers métropolitains. Le district à tungstène de Puy-lesVignes (87). Rapport BRGM/RP-66905-FR, 46 p.

Michaud JAS, Pichavant M. 2019. The H/F ratio as an indicator of contrasted wolframite deposition mechanisms. Ore Geology Reviews 104: 266-272.

Michaud JAS, Gumiaux C, Pichavant M, Gloaguen E, Marcoux E. 2020. From magmatic to hydrothermal $\mathrm{Sn}-\mathrm{Li}-(\mathrm{Nb}-\mathrm{Ta}-\mathrm{W})$ mineralization: The Argemela area (central Portugal). Ore Geology Reviews 116: 103215.

Moine B, Guillot C, Gibert F. 1994. Controls of the composition of nitrogen-rich fluids originating from reaction with graphite and ammonium-bearing biotite. Geochimica et Cosmochimica Acta 58: 5503-5523.

Monecke T, Monecke J, Reynolds TJ, Tsuruoka S, Bennett MM, Skewes WB, et al. 2018. Quartz solubility in the $\mathrm{H}_{2} \mathrm{O}-\mathrm{NaCl}$ system: A framework for understanding vein formation in porphyry copper deposits. Economic Geology 113: 1007-1046.

Monnier L, Salvi S, Jourdan V, Sall S, Bailly L, Melleton J, et al. 2020. Contrasting fluid behavior during two styles of greisen alteration leading to distinct wolframite mineralizations: The Echassières district (Massif Central, France). Ore Geology Reviews 124: 103648.

Moritz R. 2006. Fluid salinities obtained by infrared microthermometry of opaque minerals: Implications for ore deposit modeling - A note of caution. Journal of Geochemical Exploration 89: 284-287.

Mourey Y. 1985. Le leucogranite à topaze de Chavence. Un nouvel exemple de massif à Sn, W, Li dans le Nord du Massif Central Français. Comptes Rendus de l'Académie des Sciences 300: 951-954.

Mouthier B. 2005. La mine de tungstène de Puy-les-Vignes (HauteVienne). Connaissance et Sauvegarde de Saint-Léonard, 2 éd., 256 p.

Moyen JF, Laurent O, Chelle-Michou C, Couzinié S, Vanderhaeghe O, Zeh A, et al. 2017. Collision vs. subduction-related magmatism: two contrasting ways of granite formation and implications for crustal growth. Lithos 277: 154-177.

Noronha F, Doria A, Dubessy J, Charoy B. 1992. Characterization and timing of the different types of fluids present in the barren and ore-veins of the W-Sn deposit of Panasqueira, Central Portugal. Mineralium Deposita 27: 72-79.

Ortelli M, Kouzmanov K, Wälle M, Ubrig N, Casanova V. 2018. Fluid inclusion studies in opaque ore minerals: I. Trace element content and physical properties of ore minerals controlling textural features in transmitted near-infrared light microscopy. Economic Geology 113: $1845-1860$.

Paquette JL, Piro JL, Devidal JL, Bosse V, Didier A, Sanac S, et al. 2014. Sensitivity enhancement in LA-ICP-MS by $\mathrm{N}_{2}$ addition to carrier gas: Application to radiometric dating of U-Th-bearing minerals. Agilent ICP-MS Journal 58: 1-5.

Pitcairn IK, Teagle DA, Kerrich R, Craw D, Brewer TS. 2005. The behavior of nitrogen and nitrogen isotopes during metamorphism and mineralization: evidence from the Otago and Alpine Schists, New Zealand. Earth and Planetary Science Letters 233: 229-246.

Poitrenaud T, Poujol M, Augier R, Marcoux E. 2019. The polyphase evolution of a late Variscan W/Au deposit (Salau, French Pyrenees): insights from REE and U/Pb LA-ICP-MS analyses. Mineralium Deposita. https://doi.org/10.1007/s00126-019-00923-2.

Pollard PJ, Pichavant M, Charoy B. 1987. Contrasting evolution of fluorine- and boron-rich tin systems. Mineralium Deposita 22: 315-321. 
Raimbault L. 1998. Composition of complex lepidolite-type granitic pegmatites and of constituent columbite-tantalite, Chèdeville, Massif Central, France. The Canadian Mineralogist 36: 563-583.

Raimbault L, Burnol L. 1998. The Richemont rhyolite dyke, Massif Central, France: a subvolcanic equivalent of rare metal granites. The Canadian Mineralogist 36: 265-282.

Raimbault L, Cuney M, Azencott C, Duthou JL, Joron JL. 1995. Geochemical evidence for a multistage magmatic genesis of $\mathrm{Ta}-$ $\mathrm{Sn}-\mathrm{Li}$ mineralization in the granite at Beauvoir, French Massif Central. Economic Geology 90: 548-576.

Ramboz C, Schnapper D, Dubessy J. 1985. The P-V-T-X-fO evolution of $\mathrm{H}_{2} \mathrm{O}-\mathrm{CO}_{2}-\mathrm{CH}_{4}$-bearing fluid in a wolframite vein: Reconstruction from fluid inclusion studies. Geochimimica et Cosmochimica Acta 49: 205-219.

Ren SK, Walshe JL, Paterson RG, Both RA, Andrew A. 1995. Magmatic and hydrothermal history of the porphyry-style deposits of the Ardlethan tin field, New South Wales, Australia. Economic Geology 90: 1620-1645.

René M, Škoda R. 2011. Nb-Ta-Ti oxides fractionation in rare-metal granites: Krásno-Horní Slavkov ore district, Czech Republic. Mineralogy and Petrology 103: 37-48.

Renne PR, Norman EB. 2001. Determination of the half-life of ${ }^{37} \mathrm{Ar}$ by mass spectrometry. Physical Review C 63: 047302.

Renne PR, Swisher CC, Deino AL, Karner DB, Owens TL, DePaolo DJ. 1998. Intercalibration of standards, absolute ages and uncertainties in ${ }^{40} \mathrm{Ar}{ }^{39} \mathrm{Ar}$ dating. Chemical Geology 145: 117-152.

Roig JY, Faure M, Ledru P. 1996. Polyphase wrench tectonics in the southern French Massif Central: kinematic inferences from preand syntectonic granitoids. Geologische Rundschau 85: 138-153.

Roig JY, Faure M, Maluski H. 2002. Superimposed tectonic and hydrothermal events during the late-orogenic extension in the Western French Massif Central: a structural and ${ }^{40} \mathrm{Ar} /{ }^{39} \mathrm{Ar}$ study. Terra Nova 14: 25-32.

Rolin P, Marquer D, Colchen M, Cartannaz C, Cocherie A, Thiery V, et al. 2009. Famenno-Carboniferous (370-320 Ma) strike slip tectonics monitored by syn-kinematic plutons in the French Variscan belt (Massif Armoricain and French Massif Central). Bulletin de la Société Géologique de France 180: 231-246.

Rolin P, Marquer D, Cartannaz C, Rossi P. 2014. Carboniferous magmatism related to progressive pull-apart opening in the western French Massif Central. Bulletin de la Société Géologique de France 185: 171-189.

Romer RL, Kroner U. 2016. Phanerozoic tin and tungsten mineralization-Tectonic controls on the distribution of enriched protoliths and heat sources for crustal melting. Gondwana Research 31: 60-95.

Rudnick RL, Gao S. 2003. Composition of the Continental Crust. Treatise on Geochemistry 3: 1-64.

Scaillet S, Cheilletz A, Cuney M, Farrar E, Archibald DA. 1996a. Cooling pattern and mineralization history of the Saint Sylvestre and western Marche leucogranite pluton, French Massif Central: I. ${ }^{40} \mathrm{Ar} /{ }^{39} \mathrm{Ar}$ isotopic constraints. Geochimica et Cosmochimica Acta 60: 4653-4671.

Scaillet S, Cuney M, Le Carlier de Veslud C, Cheilletz A, Royer JJ. 1996b. Cooling pattern and mineralization history of the Saint Sylvestre and western Marche leucogranite pluton, French Massif Central: II. Thermal modelling and implications for the mechanisms of uranium mineralization. Geochimica et Cosmochimica Acta 60: 4673-4688.

Schmidt C, Romer RL, Wohlgemuth-Ueberwasser CC, Appelt O. 2020. Partitioning of Sn and W between granitic melt and aqueous fluid. Ore Geology Reviews 117: 103263.
Schulmann K, Schaltegger U, Jezek J, Thompson AB, Edel JB. 2002. Rapid burial and exhumation during orogeny: Thickening and synconvergent exhumation of thermally weakened and thinned crust (Variscan orogen in Western Europe). American Journal of Science 302: 856-879.

Sillitoe RH. 1985. Ore-related breccias in volcanoplutonic arcs. Economic Geology 80: 1467-1514.

Skewes MA, Holmgren C, Stern CR. 2003. The Donoso copper-rich, tourmaline-bearing breccia pipe in central Chile: petrologic, fluid inclusion and stable isotope evidence for an origin from magmatic fluids. Mineralium Deposita 38: 2-21.

Solgadi F, Moyen JF, Vanderhaeghe O, Sawyer EW, Reisberg L. 2007. The role of crustal anatexis and mantle-derived magmas in the genesis of synorogenic Hercynian granites of the Livradois area, French Massif Central. The Canadian Mineralogist 45: 581-606.

Solomovich LI, Trifonov BA, Sabelnikov SE. 2012. Geology and mineralization of the Uchkoshkon tin deposit associated with a breccia pipe, Eastern Kyrgyzstan. Ore Geology Reviews 44: 59-69.

Somarin AK, Ashley P. 2004. Hydrothermal alteration and mineralisation of the Glen Eden Mo-W-Sn deposit: a leucogranite-related hydrothermal system, Southern New England Orogen, NSW, Australia. Mineralium Deposita 39: 282-300.

Soufi M. 1988. Étude des magmatismes leucogranitique et ongonitique de Blond (Haut Limousin, Massif Central Français). Relations avec une mise en place syntectonique du massif granitique. Unpublished Ph.D. Thesis, Université de Nancy, France, 304 p.

Spell TL, McDougall I. 2003. Characterization and calibration of ${ }^{40} \mathrm{Ar} /{ }^{39} \mathrm{Ar}$ dating standards. Chemical Geology 198: 189-211.

Steele-MacInnis M, Lecumberri-Sanchez P, Bodnar RJ. 2012. Short note: HokieFlincs_H2O-NaCl: a Microsoft Excel spreadsheet for interpreting microthermometric data from fluid inclusions based on the PVTX properties of $\mathrm{H}_{2} \mathrm{O}-\mathrm{NaCl}$. Computers \& Geosciences 49: 334-337.

Steiger RH, Jäger E. 1977. Subcommission on geochronology: convention on the use of decay constants in geo- and cosmochronology. Earth and Planetary Science Letters 36: 359-362.

Sterner SM, Bodnar RJ. 1984. Synthetic fluid inclusions in natural quartz I. Compositional types synthesized and applications to experimental geochemistry. Geochimica et Cosmochimica Acta 48: 2659-2668.

Stussi JM. 1989. Granitoid chemistry and associated mineralization in the French Variscan. Economic Geology 84: 1363-1381.

Thiéry V, Rolin P. 2012. Notice explicative de la carte géologique d'Ussel au 1/50 000, 715. Orléans : Éditions BRGM.

Thiéry R, Van Den Kerkhof AM, Dubessy J. 1994. vX properties of $\mathrm{CH}_{4}-\mathrm{CO}_{2}$ and $\mathrm{CO}_{2}-\mathrm{N}_{2}$ fluid inclusions: modelling for $\mathrm{T}<31{ }^{\circ} \mathrm{C}$ and $\mathrm{P}<400$ bars. European Journal of Mineralogy 6: 753-771.

Thompson AB, Connolly JA. 1992. Migration of metamorphic fluid: some aspects of mass and heat transfer. Earth-Science Reviews 32: 107-121.

Thompson JFH, Sillitoe RH, Baker T, Lang JR, Mortensen JK. 1999. Intrusion-related gold deposits associated with tungsten-tin provinces. Mineralium Deposita 34: 323-334.

Timofeev A, Migdisov AA, Williams-Jones AE. 2015. An experimental study of the solubility and speciation of niobium in fluoride-bearing aqueous solutions at elevated temperature. Geochimica et Cosmochimica Acta 158: 103-111.

Timofeev A, Migdisov AA, Williams-Jones AE. 2017. An experimental study of the solubility and speciation of tantalum in fluoride-bearing aqueous solutions at elevated temperature. Geochimica et Cosmochimica Acta 197: 294-304. 
Vallance J, Cathelineau M, Marignac C, Boiron MC, Fourcade S, Martineau F, Fabre C. 2001. Microfracturing and fluid mixing in granites: W-(Sn) ore deposition at Vaulry (NW French Massif Central). Tectonophysics 336: 43-61.

Van Achterbergh E, Ryan CG, Jackson SE, Griffin WL. 2001. Appendix III: Data reduction software for LA-ICP-MS. In Sylvester PJ (ed) Laser-Ablation-ICPMS in the Earth Sciences: Principles and Applications. Mineralogical Association of Canada, Short Course Series 29: 239-243.

Van den Kerkhof AM, Touret JLR, Maijer JB, Jansen BH. 1991. Retrograde methane-dominated fluid inclusions from high-temperature granulites of Rogaland, southwestern Norway. Geochimica et Cosmochimica Acta 55: 2533-2544.

Van Lichtervelde M, Salvi S, Beziat D, Linnen RL. 2007. Textural features and chemical evolution in tantalum oxides: magmatic versus hydrothermal origins for Ta mineralization in the Tanco Lower pegmatite, Manitoba, Canada. Economic Geology 102: 257-276.

Vermeesch P. 2012. On the visualisation of detrital age distributions. Chemical Geology 312: 190-194.

Villaros A, Pichavant M. 2019. Mica-liquid trace elements partitioning and the granite-pegmatite connection: The St-Sylvestre complex (Western French Massif Central). Chemical Geology 528: 119265.

Villaros A, Laurent O, Couzinié S, Moyen JF, Mintrone M. 2018. Plutons and domes: the consequences of anatectic magma extraction-example from the southeastern French Massif Central. International Journal of Earth Sciences 107: 2819-2842.

Villaseca C, Barbero L, Herreros V. 1998. A re-examination of the typology of peraluminous granite types in intracontinental orogenic belts. Earth and Environmental Science Transactions of The Royal Society of Edinburgh 89: 113-119.

Vindel E, López García JÁ, Boiron MC, Cathelineau M, Prieto Colorado ÁC. 1995. P-V-T-X-fO 2 evolution from wolframite to sulphide depositional stages in intragranitic W-veins. An example from the Spanish Central System. European Journal of Mineralogy 7: 675-688.

Vry JK, Baker JA. 2006. LA-MC-ICPMS Pb-Pb dating of rutile from slowly cooled granulites: confirmation of the high closure temperature for $\mathrm{Pb}$ diffusion in rutile. Geochimica et Cosmochimica Acta 70: 1807-20.

Wang RC, Fontan F, Monchoux P. 1992. Minéraux disséminés comme indicateurs du caractère pegmatitique du granite de Beauvoir, Massif d'Echassières, Allier, France. The Canadian Mineralogist 30: 763-770.

Wang XS, Timofeev A, Williams-Jones AE, Shang LB, Bi XW. 2019. An experimental study of the solubility and speciation of tungsten in NaCl-bearing aqueous solutions at 250,300 , and $350^{\circ} \mathrm{C}$. Geochimica et Cosmochimica Acta 265: 313-329.

Watson EB, Wark DA, Thomas JB. 2006. Crystallization thermometers for zircon and rutile. Contributions to Mineralogy and Petrology 151: 413-433.

Wei W, Hu R, Bi X, Peng J, Su W, Song S, Shi S. 2012. Infrared microthermometric and stable isotopic study of fluid inclusions in wolframite at the Xihuashan tungsten deposit, Jiangxi province, China. Mineralium Deposita 47: 589-605.
Weis P, Driesner T, Heinrich CA. 2012. Porphyry-copper ore shells form at stable pressure-temperature fronts within dynamic fluid plumes. Science 338: 1613-1616.

Weppe M. 1951. Contribution à l'étude des gîtes de tungstène français: Puy-les-Vignes (Haute Vienne), La Châtaigneraie (Cantal). Nancy: Revue de Géologie appliquée et de Prospection minière, Société d'Impressions Typographiques, $210 \mathrm{p}$.

Weppe M. 1958. Contribution à la géologie minière et à la minéralogie minière. Les gisements de wolfram de Leucamp, Puy-les-Vignes, Montbelleux. Nancy: Société d'Impressions Typographiques, $196 \mathrm{p}$.

Williamson BJ, Shaw A, Downes H, Thirlwall MF. 1996. Geochemical constraints on the genesis of Hercynian two-mica leucogranites from the Massif Central, France. Chemical Geology 127: 25-42.

Wood SA, Samson IM. 2000. The hydrothermal geochemistry of tungsten in granitoid environments: I. Relative solubilities of ferberite and scheelite as a function of $\mathrm{T}, \mathrm{P}, \mathrm{pH}$, and $\mathrm{mNaCl}$. Economic Geology 95: 143-182.

Wu M, Samson IM, Zhang D. 2018. Textural features and chemical evolution in $\mathrm{Ta}-\mathrm{Nb}$ oxides: implications for deuteric rare-metal mineralization in the Yichun granite-marginal pegmatite, Southeastern China. Economic Geology 113: 937-960.

Yang K, Bodnar RJ. 2004. Orthomagmatic origin for the Ilkwang $\mathrm{Cu}-$ W breccia-pipe deposit, southeastern Kyongsang Basin, South Korea. Journal of Asian Earth Sciences 24: 259-270.

Yardley BWD, Graham JT. 2002. The origins of salinity in metamorphic fluids. Geofluids 2: 249-256.

Zack T, Stockli D, Luvizotto G, Barth M, Belousova E, Wolfe M, et al. 2011. In situ U-Pb rutile dating by LA-ICP-MS: ${ }^{208} \mathrm{~Pb}$ correction and prospects for geological applications. Contributions to Mineralogy and Petrology 162: 515-530.

Zajacz Z, Halter WE, Pettke T, Guillong M. 2008. Determination of fluid/melt partition coefficients by LA-ICP-MS analysis of co-existing fluid and silicate melt inclusions: controls on element partitioning. Geochimica et Cosmochimica Acta 72: 2169-2197.

Zaraisky GP, Korzhinskaya V, Kotova N. 2010. Experimental studies of $\mathrm{Ta}_{2} \mathrm{O}_{5}$ and columbite-tantalite solubility in fluoride solutions from 300 to $550{ }^{\circ} \mathrm{C}$ and 50 to $100 \mathrm{MPa}$. Mineralogy and Petrology 99: $287-300$.

Zhu JC, Li RK, Li FC, Xiong XL, Zhou FY, Huang XL. 2001. Topazalbite granites and rare metal mineralization in the Limu district, Guangxi Province, southeast China. Mineralium Deposita 36: 393-405.

Zhu ZY, Wang RC, Che XD, Zhu JC, Wei XL, Huang XE. 2015. Magmatic-hydrothermal rare-element mineralization in the Songshugang granite (northeastern Jiangxi, China): Insights from an electron-microprobe study of $\mathrm{Nb}-\mathrm{Ta}-\mathrm{Zr}$ minerals. Ore Geology Reviews 65: 749-760.

Zhu ZY, Wang RC, Marignac C, Cuney M, Mercadier J, Che XD, et al. 2019. Petrogenesis of $\mathrm{Nb}-(\mathrm{Ta})$ aplo-pegmatites and finegrained granites from the Early Cretaceous Huangshan rare-metal granite suite, northeast Jiangxi Province, southeast China. Lithos 346-347: 105150.

Cite this article as: Harlaux M, Marignac C, Mercadier J, Poujol M, Boiron M-C, Kouzmanov K, Camacho A, Alikouss S, Roméo B, Mouthier B, Cuney M. 2021. Multistage development of a hydrothermal W deposit during the Variscan late-orogenic evolution: the Puy-lesVignes breccia pipe (Massif Central, France), BSGF - Earth Sciences Bulletin 192: 33. 